University of Rhode Island

DigitalCommons@URI

Open Access Dissertations

2018

\title{
VALUE CHAIN IMPROVEMENTS IN SMALL-SCALE FISHERIES: CASE STUDIES FROM WEST AFRICA
}

Kristine Beran

University of Rhode Island, kristine_beran@uri.edu

Follow this and additional works at: https://digitalcommons.uri.edu/oa_diss

\section{Recommended Citation}

Beran, Kristine, "VALUE CHAIN IMPROVEMENTS IN SMALL-SCALE FISHERIES: CASE STUDIES FROM WEST AFRICA" (2018). Open Access Dissertations. Paper 785.

https://digitalcommons.uri.edu/oa_diss/785

This Dissertation is brought to you for free and open access by DigitalCommons@URI. It has been accepted for inclusion in Open Access Dissertations by an authorized administrator of DigitalCommons@URI. For more information, please contact digitalcommons-group@uri.edu. 


\author{
VALUE CHAIN IMPROVEMENTS IN SMALL-SCALE \\ FISHERIES: CASE STUDIES FROM WEST AFRICA \\ BY \\ KRISTINE BERAN
}

\begin{abstract}
A DISSERTATION SUBMITTED IN PARTIAL FULFILLMENT OF THE REQUIREMENTS FOR THE DEGREE OF

DOCTOR OF PHILOSOPHY
\end{abstract}

IN

MARINE AFFAIRS

UNIVERSITY OF RHODE ISLAND

2018 


\section{DOCTOR OF PHILOSOPHY DISSERTATION}

$\mathrm{OF}$ KRISTINE BERAN

\section{APPROVED:}

Major Professor Richard Burroughs

Elin C. Torell

Brian R. Crawford

Hiro Uchida

Nasser H. Zawia

DEAN OF THE GRADUATE SCHOOL

\section{UNIVERSITY OF RHODE ISLAND}

2018 


\begin{abstract}
Seafood is one of the most traded food commodities in the world by value. Smallscale fisheries contribute significantly to the global production and supply of seafood. Yet, many small-scale fisheries in developing countries fail to maximize value of seafood products due to post-harvest loss, production, distribution, and marketing challenges. The purpose of this study is to examine how post-harvest innovations might address some of these challenges, whom they benefit along the fisheries value chain, and factors that influence adoption of innovations through two case studies in West Africa.
\end{abstract}

A multi-methods approach was used to collect extensive quantitative and qualitative data from two countries, The Gambia and Ghana, during the period between 2015-2018. Data were collected in the field using paper and electronic survey instruments. These data were analyzed statistically and supported with key informant interviews, focus groups, and direct and participant observation.

The results of this study show that in the Gambian sole fishery a simple innovation, icing at sea, improved quality and reduced loss, thus increasing revenue from export-oriented sole for fishers and buyers. Results also suggest that increasing the proportion of sole for export does not impact local trade and consumption of sole. In Ghana, a slightly more complex innovation was introduced to improve quality of smoked fish and reduce consumption of fuelwood used to smoke fish. Results indicate that innovative technology reduces fuelwood consumption, improves quality and points to increased profitability for processors. This study also measured factors that influence adoption of innovative technology. Factors that influence adoption are 
distinct technological features such as less consumption of fuelwood, hence, cost of fuelwood, reduction of smoke, and hands-on training, plus the ability to pay for innovative technology. This study highlights the importance of simplicity in designing and implementing innovations within the post-harvest sector in small-scale fisheries in developing countries. These findings suggest post-harvest innovations can have positive socio-economic impacts for some nodes along the fisheries value chain, however, the cost of the innovation may exceed the benefit for other nodes along the chain in the case studies presented here. 


\section{ACKNOWLEDGMENTS}

I sincerely thank my co-advisors, Dr. Richard Burroughs and Dr. Elin Torell, for their exceptional guidance, support and supervision of my research throughout my time at the University of Rhode Island. I would also like to thank my committee, beginning with Dr. Brian Crawford. Dr. Crawford, thank you for inspiring me to pursue a Doctorate in Marine Affairs. Dr. Richard Pollnac, I thank you for dedicating your time to my research, sharing your expertise and appreciating my passion for it. Dr. Hiro Uchida and Dr. Donna Hughes, you have guided my research from distinct yet very significant perspectives, I am grateful for the support you have shown me over the years and your continued interest in my work. In addition to my committee, I would like to thank Dr. Kathleen Castro and Ms. Laura Skrobe from the Fisheries Center at the University of Rhode Island for building my skill set, beginning in the field. I wish to thank Dr. Catherine McNally, Dr. Elizabeth McLean, and Dr. Dawn Kotowicz for their guidance and friendship.

I extend my gratitude to the Coastal Resources Center at the University of Rhode Island Graduate School of Oceanography which was instrumental in the development and successful completion of my research. I give special recognition to Ms. Karen Kent and Dr. Don Robadue, Jr. For research conducted in The Gambia, I would like to thank Mr. Dawda Foday Saine from NASCOM, the Atlantic Seafood Company and the Statistics Unit at the Department of Fisheries for collaborating and sharing their knowledge with me. For research conducted in Ghana, I would like to thank the USAID/Ghana Sustainable Fisheries Management Project, and especially Ms. Hannah Antwi. My research would not have been possible, however, without fishers and 
processors from Alaska to West Africa who shared their knowledge to increase mine. To friends and family from Rhode Island to Bainbridge Island, I appreciate your support of my academic pursuits. Gracias, Javier. 


\section{PREFACE}

This dissertation is comprised of four chapters, which are organized into three manuscripts. Each manuscript follows the University's requirements for "manuscript format." Chapter one provides an overview of theoretical frameworks and important themes discussed throughout this dissertation, and introduces a conceptual model for implementing value chain innovations in small-scale fisheries in developing countries. Chapter two and chapter three are case studies from West Africa that inform the conceptual model introduced in chapter one in slightly different ways. Chapter two is an assessment of post-harvest loss of sole in The Gambia. Chapter three measures adoption of improved fish smoking technology in Ghana. Each case study is presented as a separate manuscript for publication. Chapter four summarizes each case study; it discusses results, cross-cutting themes present in both case studies, practical and theoretical implications of this research, and thematic areas for future research. I intend to combine chapter one and chapter four into one manuscript for publication after each case study is accepted for publication. Each manuscript is designed for the following scientific journals:

Manuscript $1^{1}$ has been submitted to Marine Policy.

Manuscript $2^{2}$ to be submitted to World Development.

Manuscript $3^{3}$ to be submitted to Global Food Security.

${ }^{1}$ This manuscript refers to chapter two of this dissertation.

2 This manuscript refers to chapter three of this dissertation.

${ }^{3}$ This manuscript is a combination of chapter one and chapter four of this dissertation. 


\section{TABLE OF CONTENTS}

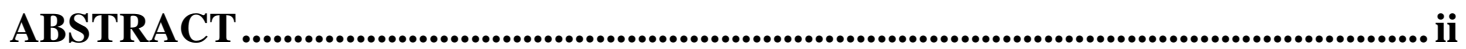

ACKNOWLEDGMENTS ................................................................................................. iv

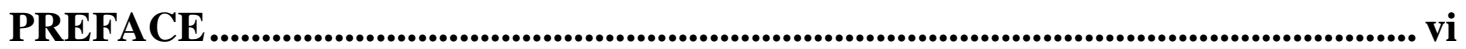

TABLE OF CONTENTS........................................................................................... vii

LIST OF TABLES .............................................................................................................. $\mathrm{x}$

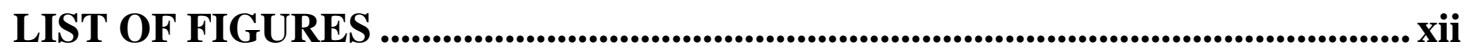

LIST OF ACRONYMS .............................................................................................

Chapter 1 ...................................................................................................................................... 1





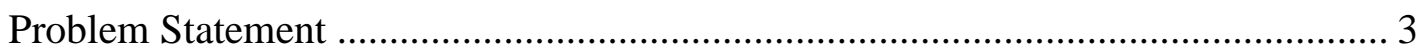

State of Knowledge ......................................................................................... 4

Conceptual Framework ...................................................................................... 10

Cross-cutting Themes of the Framework ………………………............................ 17

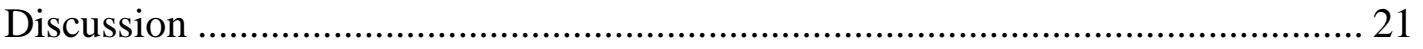

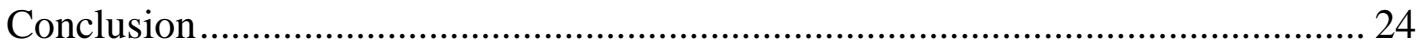

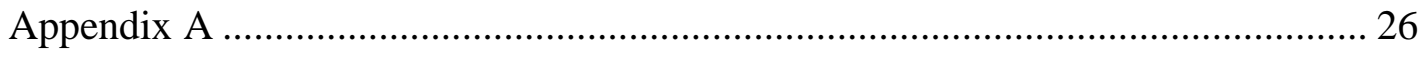

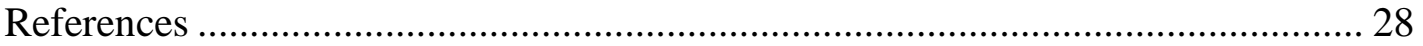

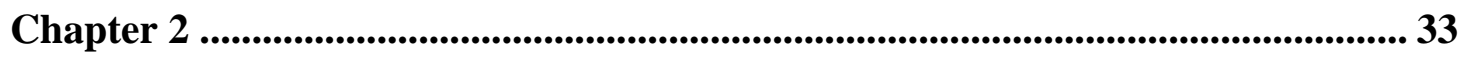

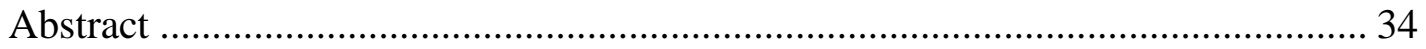

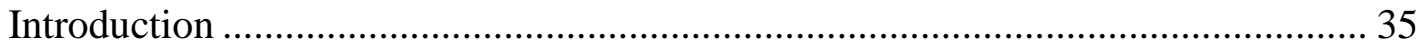

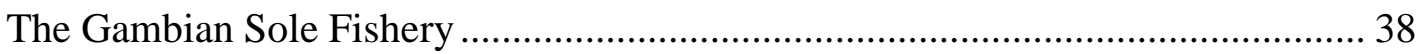

A Management and Market in Transition ............................................................... 39

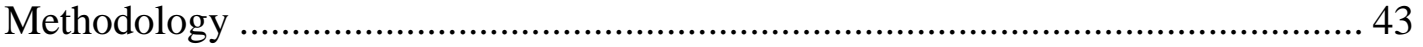

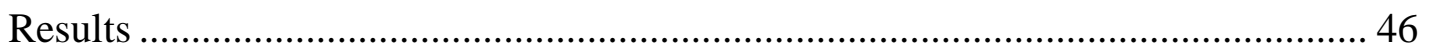

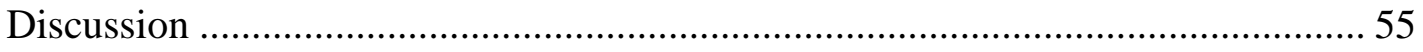




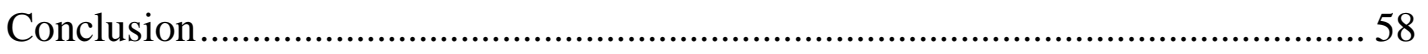

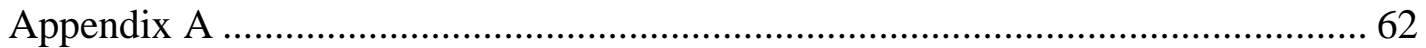



Chapter 3 ........................................................................................................................................... 71

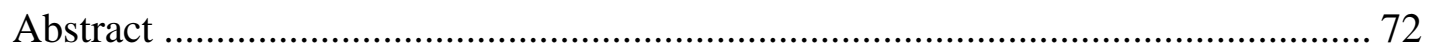

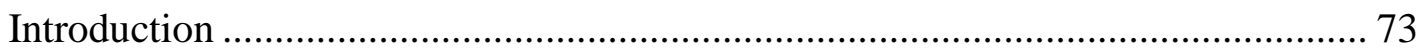

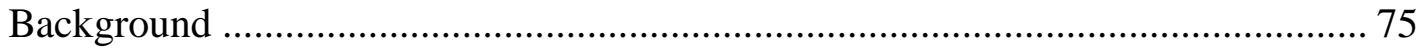

Evolution of Stove Technology in Ghana ……………………………………...... 76

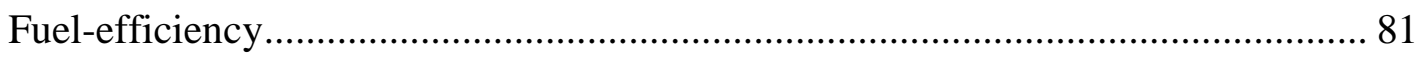

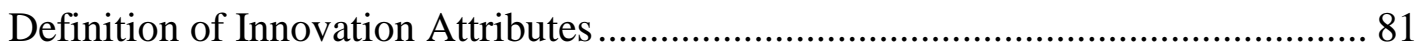

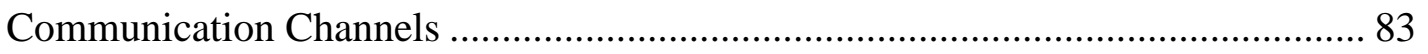

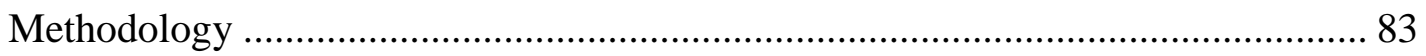

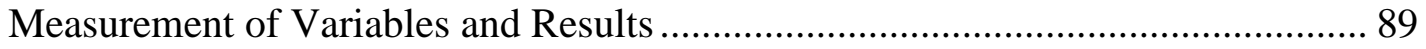

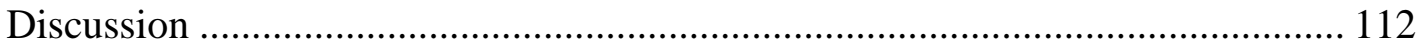

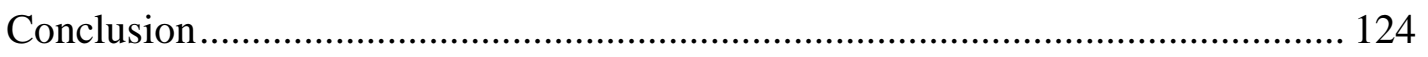

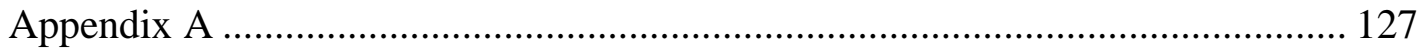

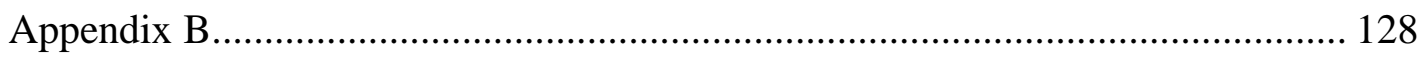

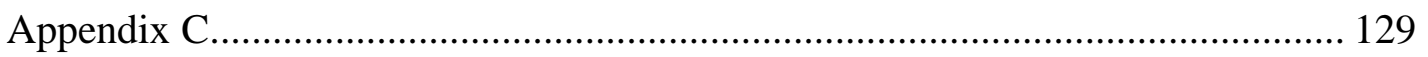

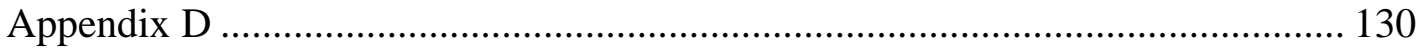

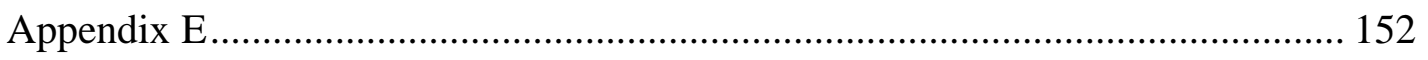

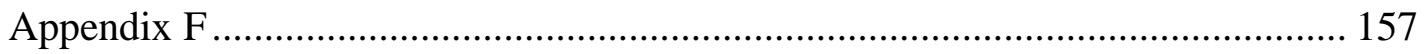

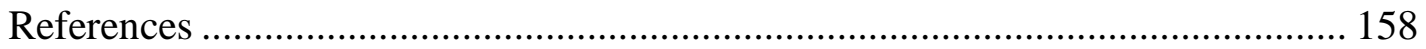



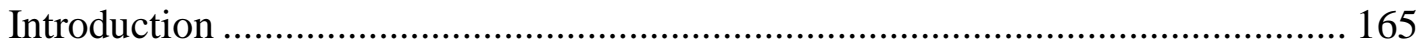

Summary of Results by Node.............................................................................. 166

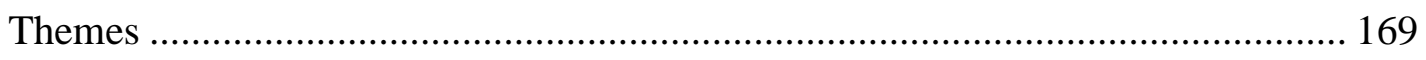



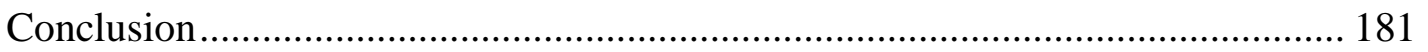

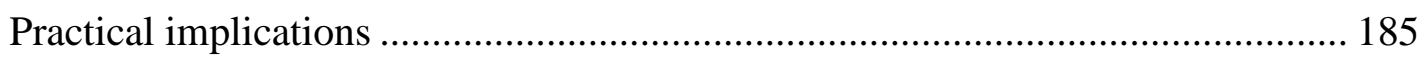

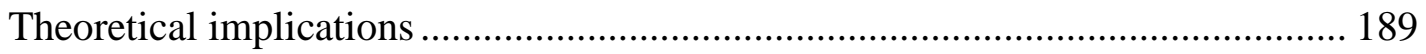




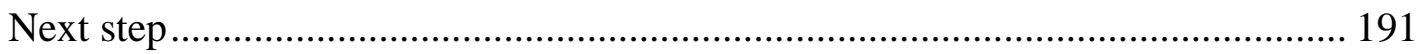

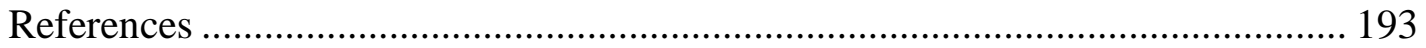

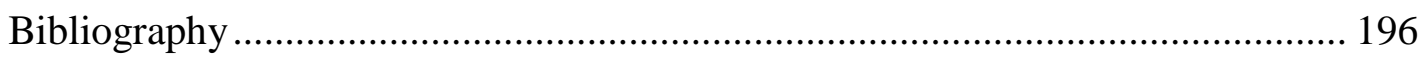




\section{LIST OF TABLES}

TABLE

PAGE

Table 2.1. Fisheries improvement projects in the Gambian sole fishery.................... 40

Table 2.2. Quality scores of sole landings in kilograms (kg). ................................. 46

Table 2.3. Quality scores of sole landings by proportion (\%). ................................. 47

Table 2.4. Average fisherman’s proportion loss of sole. ..................................... 48

Table 2.5. Average fisherman’s proportion loss of red and black sole....................... 48

Table 2.6. Average fishermen's daily revenue from sole excluding price of ice......... 49

Table 2.7. Average fishermen's daily revenue from sole including price of ice........ 50

Table 2.8. Average buyer's proportion loss from sole based on fishermen's use of ice.

Table 2.9. Average buyer’s daily revenue from sole based on fishermen’s use of ice.51

Table 2.10. Difference between ranks of fish at two landing sites for sole in The

Gambia. 53

Table 2.11. Contribution of fish smoking to overall household income by fish

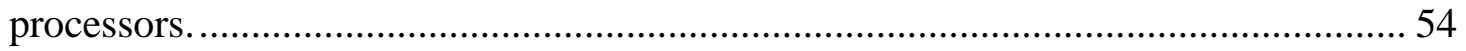

Table 2.12. Impact of sole exports on local trade................................................. 55

Table 3.1. Owners of ahotor stove by region (as of August, 2017) .......................... 86

Table 3.2. Selection criteria for ahotor stove beneficiaries by region. ....................... 87

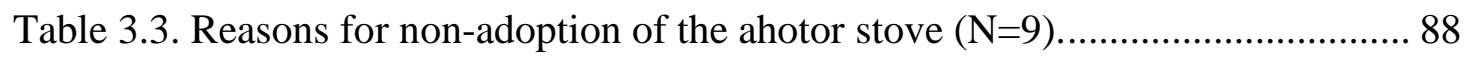

Table 3.4. Description of socio-economic variables.............................................. 90

Table 3.5. Difference between and within groups of socio-economic variables......... 91

Table 3.6. Material style of life indicators. ....................................................... 93 
Table 3.7. Principal component analysis of material style of life $(n=111) \ldots \ldots \ldots \ldots \ldots . . . .94$

Table 3.8. Differences between groups with respect to Household goods. ................ 96

Table 3.9. Differences between groups with respect to Luxury items....................... 96

Table 3.10. Attributes, subset of questions, and measurement for scale construction. 98

Table 3.11. Principal component analysis of Rogers (1995) attributes $(n=111) \ldots . . .100$

Table 3.12. Innovation attributes component scores across user groups. ................. 102

Table 3.13. Logit coefficients from model of adoption of ahotor stove.................. 104

Table 3.14. Analysis of perceived changes of availability of fish and fuelwood. ..... 108

Table 3.15. Differences between ahotor and chorkor groups regarding Fuelwood ${ }_{\text {T2-T1. }}$

Table 3.16. Expense of fuelwood by respondent type......................................... 109

Table 3.17. Sales of fish at the market by stove type........................................ 110

Table 3.18. Perception of quality of smoked fish by respondent type..................... 111 


\section{LIST OF FIGURES}

FIGURE

PAGE

Figure 1.1. Value chain upgrading framework for small-scale fisheries. ................... 11

Figure 1.2. Nodes in a fishery value chain......................................................... 12

Figure 2.1. Governance structure for the sole fishery in The Gambia ....................... 40

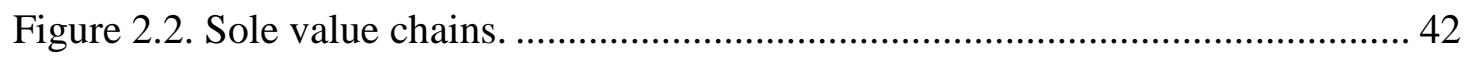

Figure 2.3. Map of study sites and special management area for sole, The Gambia... 44

Figure 3.1. PAHs levels by stove types......................................................... 80

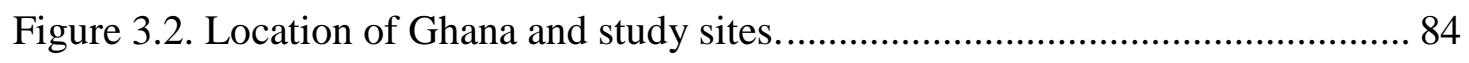

Figure 3.3. Location of sample sites by region in Ghana........................................ 85

Figure 3.4. Principal component scores for household goods and luxury items and

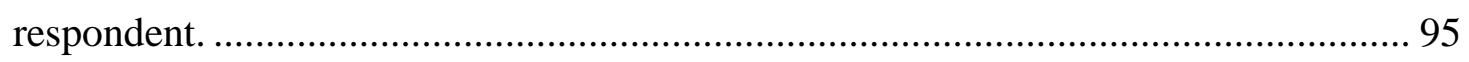

Figure 3.5. Coughing in relation to the ahotor stove......................................... 111 


\section{LIST OF ACRONYMS}

\begin{tabular}{|c|c|}
\hline ANOVA & Analysis of Variance \\
\hline $\mathrm{BaP}$ & Benzo[a]pyrene \\
\hline CAC & Codex Alimentarius Code \\
\hline CCLME & Canary Current Large Marine Ecosystem \\
\hline CSIR & Council for Scientific and Industrial Research \\
\hline DoFISH & Department of Fisheries \\
\hline EFLAM & Exploratory Fish Loss Assessment Method \\
\hline FAO & Food and Agriculture Organization \\
\hline FIP & Fishery Improvement Project \\
\hline FoN & Friends of the Nation \\
\hline FRI & Food Research Institute \\
\hline GSA & Ghana Standards Authority \\
\hline LACOM & Landing Site Co-Management Committee \\
\hline LT & Load Tracking \\
\hline MASLOC & Microfinance and Small Loans Centre \\
\hline MSC & Marine Stewardship Council \\
\hline MSL & Material Style of Life \\
\hline NASCOM & National Sole Fishery Co-Management Committee \\
\hline PAH & Polycyclic Aromatic Hydrocarbon \\
\hline PHLA & Post-Harvest Loss Assessment Approach \\
\hline QLAM & Questionnaire Fish Loss Assessment Method \\
\hline
\end{tabular}


SDG

SFMP

SNV

TASC

USAID

VCA

WHO
Sustainable Development Goal

Sustainable Fisheries Management Project

Netherlands Development Association

The Atlantic Seafood Company

United States Agency for International Development

Value Chain Approach

World Health Organization 


\title{
Chapter 1
}

\section{A FRAMEWORK FOR IMPLEMENTING VALUE CHAIN IMPROVEMENTS IN SMALL-SCALE FISHERIES IN DEVELOPING COUNTRIES}

\author{
by \\ Kristine Beran $^{1}$ \\ To be submitted to Global Food Security
}

${ }^{1} \mathrm{PhD}$ Candidate, Department of Marine Affairs, University of Rhode Island, RI, 02881, USA, Email: kristine_beran@uri.edu. 


\begin{abstract}
Seafood is one of the most traded food commodities in the world by value. Yet, it is subject to various types of post-harvest loss that result in economic losses and contribute to nutrition loss and food insecurity. A review of the literature suggests there are opportunities for innovations in small-scale fisheries in developing countries to improve quality of seafood and reduce loss. Promising innovations include improved technologies used at-sea and on land. I propose a conceptual framework to upgrade value chain nodes through post-harvest innovations. This framework includes a five-step process that begins with describing the value chain, identifying losses to design innovations that result in adoption and yield socio-economic benefits.

Keywords: Small-scale fisheries, value chains, upgrading, gender, food security, biodiversity
\end{abstract}

\title{
Introduction
}

Globalization has redefined production, trade and consumption of products we use and consume. Seafood is no exception. In fact, seafood is a prime example of globalization. In terms of trade value, seafood is one of the most traded food commodities in the world surpassing coffee, cocoa, sugar, maize and it is larger than pork and poultry combined (Asche, Bellemare, Roheim, Smith, \& Tveteras, 2015). Beyond trade, fish and seafood is an important source of protein that many of the world's poorest economies depend on for food security (Food and Agriculture Organization [FAO], 2008). Seafood originates from two primary production techniques; marine capture and aquaculture (Asche et al., 2015). This dissertation 
centers on value chains related to post-harvest seafood processing technologies from marine capture production in small-scale fisheries in developing countries.

Small-scale fisheries ${ }^{2}$ contribute significantly to the global supply and production of seafood. It is estimated that small-scale fisheries from developing countries produce half of the world's fish landings (FAO, 2018). Over 90 percent of the catch from small-scale fishers is destined for human consumption (WorldFish, 2008). Small-scale fisheries often fail to maximize value of seafood products due to production, distribution and marketing challenges (Da Silva, 2011). Challenges include poor handling practices and infrastructure (e.g. storage, transportation, market) that contribute to various types of post-harvest loss (Da Silva, 2011). Addressing loss of fish is important to feed the world's growing appetite and need for seafood as a source of protein.

\section{Problem Statement}

According to the Food and Agriculture Organization of the United Nations (FAO, 2014), small-scale fisheries in developing countries are subject to significant post-harvest losses that lead to "reductions in the quantity, quality or monetary value of fish” (109-110). The FAO (2014) estimates that the cumulative loss ranges between 20 and 75 percent from the point of production until consumption (110). Physical loss ${ }^{3}$ of fish is lowest, or less than 10 percent, whereas quality-related loss can account for up to 70 percent of total loss (FAO, 2014). Poor and inefficient fish preservation techniques contribute to quality-related post-harvest loss in small-scale fisheries.

${ }^{2}$ FAO (2018) defines small-scale fisheries as fishing households that use a relatively small amount of capital and energy, use relatively small fishing vessels and make short trips mainly for local food consumption.

${ }^{3}$ Defined as discard due to animal predation and insect infestation. 
Upgrades, or innovations in quality and processing technology can improve fish quality and reduce post-harvest loss. Upgrading is a broad term that is subsequently discussed.

This dissertation empirically analyzes ${ }^{4}$ how a node, or a network of people in the value chain are impacted by post-harvest ${ }^{5}$ innovations, or upgrades. Overarching questions that lead to the development of a conceptual framework for implementing upgrades are:

1. What is the theory behind reducing post-harvest loss and in that sense upgrading small-scale fisheries in West Africa?

2. What are some socio-economic outcomes of value chain upgrades, who benefits, and how do these outcomes align with or contradict theory?

3. What factors influence adoption of innovations among its users?

\section{State of Knowledge}

A literature review was conducted to search for theoretical frameworks applicable for addressing both post-harvest loss and value chain upgrades in smallscale fisheries in developing countries. The review extended beyond fisheries to agriculture to understand how they differ with respect to upgrading of other perishable food products.

The review was conducted in a systematic way by searching for information using online databases. Relevant articles and studies were identified by searching Aquatic Sciences and Fisheries Abstracts (ASFA), AGRICOLA (ProQuest),

\footnotetext{
${ }^{4}$ Analytic process is shown in Appendix A.

${ }^{5}$ Post-harvest refers to the moment a fish enters a net is captured in a trap, or on a hook (Ward \& Jefferies, 2000).
} 
Biological and Agricultural Index Plus, and Scopus. There was no limitation placed on a time period, however, the term "upgrading" has been recently linked to fisheries value chain literature. Most articles referenced were published post-2000. An advanced search using key phrases and terms such as post-harvest loss, small scale, value chains and upgrading were used in every database mentioned.

The FAO’s Post-Harvest Loss Assessment Approach (PHLA) is suited for small-scale fisheries operating in the sub-Saharan African context (Akande \& DieiOuadi, 2010). Here, losses occur for many reasons such as poor handling, inefficient processing and preservation techniques, exposure to high temperatures, lack of storage, poor transportation and theft (Akande \&Diei-Ouadi, 2010).

This framework assesses post-harvest physical, quality and market loss of fish (Akande \& Diei-Ouadi, 2010). It defines physical loss as discards, or fish that is thrown away accidentally or intentionally (Akande \& Diei-Ouadi, 2010). Accidental discard is typically caused by severe spoilage (e.g. exposure to high temperature), insect infestation or animal predation (Akande \& Diei-Ouadi, 2010). An example of intentional discard is the controversial practice of shark finning, or when only part of the fish has market value and the rest (edible portions) is discarded. Eviscerated, or gutted fish is not considered discard according to a report published by the FAO (Kelleher, 2005). Drying fish (e.g. loss of moisture) results in weight loss, yet this processing technique is not defined as physical loss in this study, because, eviscerating wet medium to large fish species soon after they have been harvested not only prevents spoilage but may increase its value (Huss, 1988). Likewise preserving the natural moisture content of fish retains important nutrients and flavor. In fact, in sub- 
Saharan Africa this technique prevents quality loss and is discussed in chapter 3. Physical damage to fish, such as breakage or severe burning due to over smoking also results in quality loss (Akande \& Diei-Ouadi, 2010).

Quality loss is caused by spoilage, mishandling, poor packaging and lack of storage facilities that can result in economic loss, expressed as lower prices (Akande \& Diei-Ouadi, 2010). Market loss results from unfavorable market conditions, such as over-supply (Akande \&Diei-Ouadi, 2010). Another type of loss discussed, but not quantified by this approach is nutritional loss. ${ }^{6}$ All of these losses have financial, food safety and security implications for consumers.

Similar types and magnitude of post-harvest loss occur in small-scale agriculture in sub-Saharan Africa (Affognon, Mutungi, Sanginga, \& Borgemeister, 2015). Like fish, fruits and vegetables are highly susceptible to post-harvest loss (Affognon et al., 2015). A complimentary framework to the FAO’s PHLA (Akande \& Diei-Ouadi, 2010) is the Commodity Systems Assessment Methodology (LaGra, 1990). This method is used by the agri-food industry to qualify and quantify postharvest losses (LaGra, 1990). It focuses on shelf-life, or the length of time a product remains usable. A shorter shelf-life translates to qualitative and quantitative losses (LaGra, 1990). Given the globalized nature of seafood trade, this concept is highly desirable and applicable to fisheries. Techniques used in the agri-food industry

\footnotetext{
${ }^{6}$ Post-harvest nutrient loss of low-value fish processed by traditional methods in Africa is examined by Kabahenda, Omony, \& Hüsken (2009). Fish (fresh or processed) is prone to microbial growth when it is exposed to various types of oxidation and enzymatic processes leading to rancidity and rapid degradation. Degradation of fish compromises intake of nutrients such as protein, essential fatty acids, vitamin A, among others, and decreases its nutritive value. In this context, loss of nutrients is caused by excessive exposure to high temperatures, poor handling, processing and storage of fish.
} 
presented by Affognon et al. (2015) include modified atmosphere packaging, a mixture of carbon dioxide and nitrogen gas that prevents spoilage and extends shelflife. This food preservation technique is commonly used in the retail-case ready meat department and is gaining attention in seafood (Cooksey, 2014). This technique requires substantial investment in processing equipment and temperature-controlled infrastructure. Parry (2012) discusses use and expansion of this technique primarily in North America and Europe. However, conceptually, the idea behind improved packaging is transferable to small-scale fisheries, especially those with export markets.

Upgrading is a term used in value chain literature by a variety of industries, including natural resources (Gereffi, 1999; Riisgaard, Bolwig, Ponte, Toit, Halberg, \& Matose, 2010; Barrientos, Gereffi \& Rossi, 2011; Piertrobelli \& Rabellotti, 2011; Ponte, Kelling, Jespersen, \& Kruijssen, 2014; Hamilton-Hart \& Stringer, 2016). Economic upgrading refers value addition generated by profits, technology or knowledge (Bair, 2008). Examples of economic upgrading include process (e.g. efficiencies) or product (e.g. diversification) upgrading (Hamilton-Hart \& Stringer, 2016). Social upgrading refers to improvements to labor standards and quality of employment (Hamilton-Hart \& Stringer, 2016). Environmental upgrading aims to improve performance standards in order to reduce damage (De Marchi, Di Maria, \& Micelli, 2013). Institutional or governance upgrading is defined as interactive governance arrangements between state, private and civil society organizations and discussed by Fabinyi (2016) and Wentink, Raemaekers and Bush (2017), but not addressed in this dissertation. Wentink, Raemaekers and Bush (2017) use allocation of communal fishing rights as an example of institutional upgrading. 
Barrientos, Gereffi and Rossi (2011) and Riisgaard et al. (2010) both discuss various types of economic upgrading within a node in global value chains. The type of economic upgrade most relevant to this dissertation is product upgrading as defined by Riisgaard et al. (2010). Product upgrading focuses on increasing or enhancing a unit's value by enhancing its features (e.g. physical quality, food safety standard, certification, traceability, packaging). The value chain improvements discussed in this dissertation fit the definition of product upgrading as defined by Riisgaard et al. (2010).

Seafood consumption is increasingly subject to analysis using the value chain approach (Porter, 1985, Gereffi \& Fernandez-Stark, 2011, Kaplinsky, 2000; Kaplinsky \& Morris, 2000). Michael Porter (1985) popularized the value chain approach as a means for corporations to identify ways to extract more value, or profit by outperforming competitors through cost advantage ${ }^{7}$ and product differentiation. ${ }^{8}$ Porter (1985) asserts significant technological innovations can achieve both. Porter (1998) describes these innovations as capital-intensive and state-of-the-art.

Descriptively, the value chain approach, or VCA, categorizes people along the chain by occupation and location (O’Neill \& Crona, 2017). Rosales et al. (2017) and O'Neill and Crona (2017) use this approach to map and describe relationships in small-scale fisheries between people and networks, or nodes. Simply defined, a node is a group people occupying similar roles along the value chain (O’Neill \& Crona, 2017). Terms vary by region. For example, describing the snoek value chain, some

\footnotetext{
${ }^{7}$ Defined as "cutting costs," or controlling for drivers that generate the highest cost in parts of the value chain (Porter, 1985).

${ }^{8}$ Defined as distinguishing a product or service from competitors, typically making products more desirable or unique (Porter, 1985).
} 
key nodes are termed producers (e.g. fishers or gleaners), buyers (e.g. intermediaries, traders), retailers and consumers (Hara, 2014). Determining which nodes to upgrade by diffusing an innovation is important given the perishable nature of fish in tropical fisheries.

Empirically, the VCA is used to quantify profit and loss-through sales transactions-between nodes (O’Neill \& Crona, 2017). This can reveal distribution of benefits within the value chain (Rosales et al., 2017; Purcell, Crona, Lalavanua, \& Eriksson, 2017). O'Neill and Crona (2017) highlight the absence of and need for data on distribution of benefits in small-scale fisheries. Both Purcell et al. (2017) and Rosales et al. (2017) conducted primary research on the distribution of benefits within the value chain in small-scale fisheries in developing countries. Rosales et al. (2017) cites fishermen earn the lowest margin among eight value chains analyzed in the Philippines. Rosales et al. (2017) maps seven of the eight value chains analyzed by species, actor or node, average selling price per actor, profit margin and governance of the value chain. In chapter 2, the sole value chain is disaggregated by end market.

Purcell et al. (2017) reveal huge variation in prices fishers and middlemen receive for the same species of dried sea cucumbers from large buyers in different locations in the Pacific Islands. Many factors influence prices (e.g. economies of scale, patron-client arrangements). This discussion is beyond the scope of this research. However, it is noteworthy to address distribution of benefits. Unequal distribution of benefits raises equity concerns and can influence the balance of power within a supply chain. Distribution of benefits based on primary research is discussed in chapter 2 . 
The VCA, PHLA and Commodity Systems Assessment Methodology can lead to upgrading in the fisheries sector. It cannot, however, predict factors that influence adoption or rejection of innovations. Diffusion of innovation is a useful and complimentary framework (Rogers, 1995). Diffusion theory has largely been informed by social problems of rural life (Rogers, 1995). Diffusion theory informs how innovations are implemented and the rate at which they are adopted, or not, based on perceived attributes. According to diffusion theory, adoption is influenced by five perceived attributes: Relative advantage, compatibility, complexity, trialability and observability (Rogers, 1995). These attributes are discussed and empirically tested in chapter 3.

\section{Conceptual Framework}

The objective of this paper is to introduce a conceptual framework to guide the design, adoption and implementation of post-harvest value chain upgrades relevant in the developing world context. Within this context are important cross-cutting themes such as gender, biodiversity and food security that shape this framework. Their particular relevance to this framework is discussed. Central to this framework is designing and implementing improvements that align with sustainable natural resource management measures. The framework is presented in Figure 1.1. 


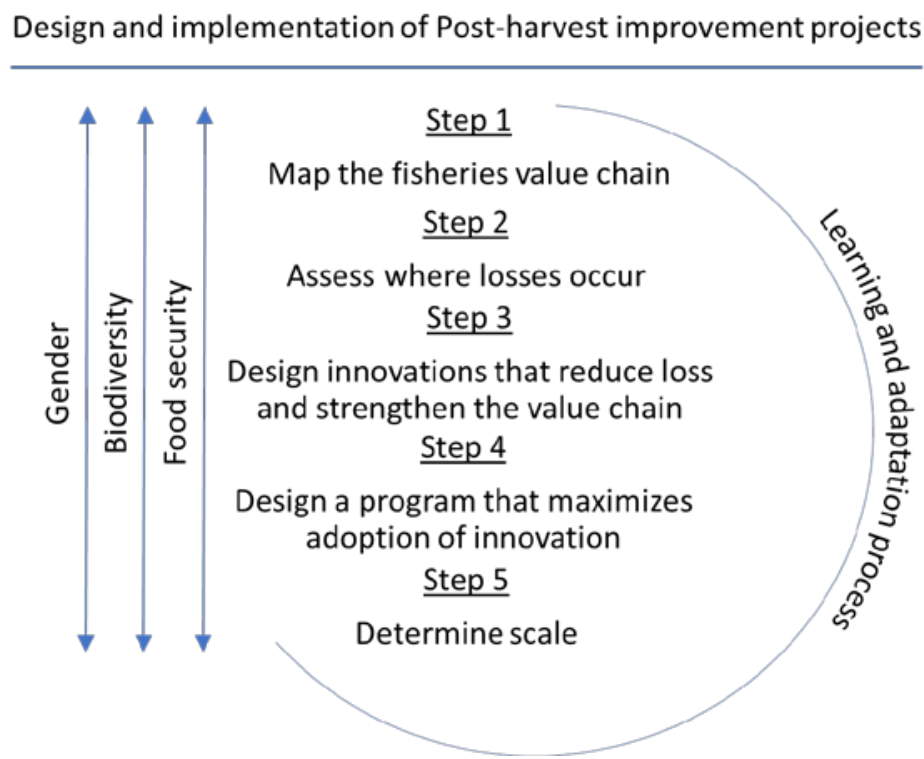

Figure 1.1. Value chain upgrading framework for small-scale fisheries.

Methods used to inform this framework include qualitative and quantitative approaches. A desktop literature review was conducted on the value chain approach and post-harvest loss related to fisheries. In step two, primary data collection (e.g. quantitative) and key informant interviews were conducted to determine post-harvest loss in the supply chain. In step three, secondary sources (e.g. value chain analyses) in addition to results from step two inform the design of interventions. Primary data collection, direct and participant observation informs implementation of programs in step four. Analysis of results from previous steps informs the learning process.

Each step is subsequently discussed, where applicable, examples based on primary research are provided by node.

Step 1: Map and describe the fisheries value chain

The first step is to understand the fisheries value chain. A value chain analysis is a useful tool for identifying opportunities and constraints to economic growth by identifying actors as nodes, describing relationships between them and structures that 
govern them. A value chain analysis was conducted for each of the two case studies discussed in this dissertation. The value chain analysis helped to identify and design post-harvest improvements discussed in this dissertation. The goal behind using this approach is to maximize value creation and/or usage of seafood products along the chain.

Step 2: Assess where losses occur in the fisheries value chain

Post-harvest improvements are typically implemented to prevent loss, reduce waste and improve usage of fish. Post-harvest loss can occur at various nodes in the value chain. Figure 1.2 illustrates value chain nodes discussed in this study. Innovations designed to reduce loss and upgrade nodes in this study are shown in parentheses (Figure 1.2).
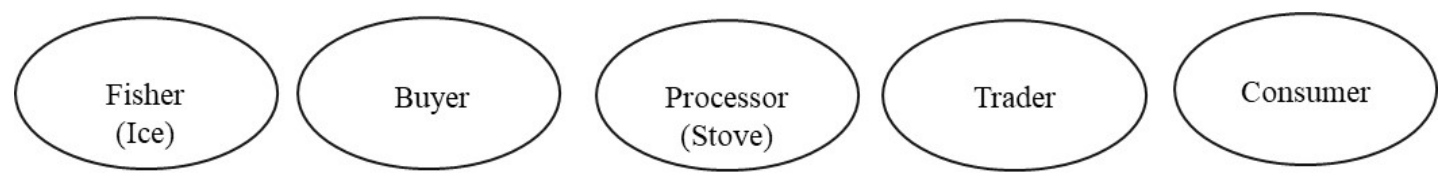

Figure 1.2. Nodes in a fishery value chain.

The FAO’s PHLA (Akande \& Diei-Ouadi, 2010) is a useful method to identify where losses occur along the value chain. This method focuses on three main types of loss (e.g. physical, quality and market force). It uses qualitative and quantitative methods to qualify and quantify losses. Akande \& Diei-Ouadi (2010) identify quantitative physical loss of fish at certain stages of distribution (not specifically by node) in five sub-Saharan African countries. In Tanzania, this study estimates 5 percent of wet and dry sardines are thrown away or discarded as a result of being stepped on aboard the vessel or infested by insects (e.g. blowflies) at the landing site (Akande \& Diei-Ouadi, 2010). Elements of the PHLA method are discussed and used 
to determine post-harvest loss in chapter 2. This method is well-suited for small-scale fisheries because it considers quality loss for domestic markets, where most fish is consumed. Understanding the magnitude and frequency of loss within a value chain is necessary to inform and design innovations that reduce loss in the value chain.

Step 3: Design innovations that reduce loss and strengthen the fisheries value chain

This step focuses on where and for whom to design innovations. While it is not limited to particular nodes, it does place emphasis on innovations around fishers and processors. As the literature suggests, these nodes often fail to capture economic gains realized by others further along the value chain. Therefore, innovations that prevent post-harvest loss, improve product quality or usage of seafood products are introduced earlier in the chain as a means of capturing more economic benefits within the fisher and processor node, but also in anticipation of strengthening nodes further along the chain.

An example of value chain strengthening is extending shelf-life, because a longer shelf-life has positive ripple effects along the entire value chain. Means used to extend shelf-life can range from simple to complex depending on the size of the investment or needs of the end market. For example, in developing world fisheries that supply local or domestic markets, improvements to traditional techniques such as salting, sun drying and smoking are rather simple, low-cost interventions that extend shelf-life of fish products in the absence of refrigeration. For fisheries with export markets, improvements to the cold chain (e.g. refrigeration or freezing) may require more substantial investments in infrastructure and logistics in exchange for higher returns. Cheke and Ward (1998) measure physical (and economic) loss using a 
model. ${ }^{9}$ Cheke and Ward (1998) provide limited, yet insightful evidence of this using a model for evaluating interventions designed to reduce post-harvest loss of Nile Perch in Tanzania. The study concluded total physical and economic loss of fish was reduced when transporting fresh fish by air rather than by rail from Lake Victoria to Dar-es-Salaam (Cheke \& Ward, 1998). In chapter 2, physical loss of sole is similarly measured according to inputs used in this model.

Other measures to reduce loss and add value may come from the financial or communication sector. For example, access to financial services such as credit and insurance schemes may facilitate and secure investments in improvements by fishers and processors. Use of electronic devices ranging from mobile phones to global positioning systems may provide access to time-sensitive price and market information that can reduce market-related losses or lead to traceability schemes that open new markets for fish products. Regardless of the size or scope of innovations, they should be highly contextualized bearing in mind the capacity of those within the chain to implement, use, and benefit from them.

\section{Step 4: Design a program that maximizes adoption of innovation}

Diffusion of innovation (Rogers, 1995) is a useful lens through which to evaluate adoption of innovations, or upgrades. It has been applied across various disciplines to help extension officers, educational institutions and researchers determine factors that influence adoption or rejection of innovations (Rogers, 1995). Factors include perceived attributes of innovations, communication channels and promotional efforts. In addition to these and other factors, there are stages a person,

\footnotetext{
${ }^{9}$ As far as physical loss is concerned, the model requires weight of fish entering each stage. At the start of the chain, weight begins with the catch.
} 
group or decision-making unit goes through before adopting an innovation (Rogers, 1995). In other words, it is not instantaneous. Each stage, beginning with knowledge or awareness creation, is critical in the adoption process. Yet even at the learning stage, there are factors that will influence-and potentially benefit-some actors more than others according to diffusion theory. For example, those who hear or learn about an innovation sooner than others tend to have a higher socio-economic status, more formal education and extended social networks (Rogers, 1995).

Applied to the fisheries value chain, socio-economic status and education characteristics differ according to nodes shown in Figure 2. Fisheries development literature often suggests fishers and processors are socio-economically marginalized with little to no formal education and high rates of illiteracy (Crawford, Herrera, Hernandaez, Leclair, Jiddawi, Masumbuko, \& Haws, 2010; Crawford, Gonzales, Amin, Nyari-Hardi, \& Sarpong, 2016; Neiland \& Béné, 2013). This is important to consider when designing-and communicating-post-harvest improvement projects according to nodes along the chain. For example, if the intended beneficiary is illiterate, printed communication about the innovation is not useful at the learning stage. In this case, a hands-on approach with respect to how-to may be more appropriate. Likewise, if the innovation is cost-prohibitive or the asset is fixed and requires ownership of land, it may benefit fewer people. Some of these factors and stages are discussed, evaluated and analyzed empirically in chapter 3.

Step 5: Determine scale

Generally, in the VCA literature scale is considered to represent impact or outcome in relation to efficiency, or economies of scale (Porter, 1985). This is a good 
measurement used in manufacturing. However, it may not be an ideal measure of success for interventions in small-scale fisheries in developing countries. In this case, the type of upgrade and its end market can also determine scale. For example, scale is defined by the number of people who potentially benefit from an intervention, or adopt an innovation. An innovation that focuses solely on export commodities may benefit some, but not all simply because many small-scale fisheries do not supply international markets (Béné \& Heck, 2005). However, if interventions target multispecies fisheries and domestic markets (e.g. small pelagic species in Ghana), the opportunity for scale increases. In other words, the type of upgrade should be tailored to the needs of the local context to achieve scale.

Learning and evaluation is an important component of this framework. Each step presents opportunities that inform the process of designing and implementing post-harvest improvement projects. For example, an evaluation of the fisheries value chain and assessment of where losses occur will help design of the intervention in step three. Step four and five will inform the future design of projects building off lessons learned through the use of this framework. The framework presented in Figure 1.1 can also inform how upgrades might impact the wider social-ecological system. Akande \& Diei-Ouadi (2010) identify a relationship between types of post-harvest loss and gender using descriptive statistics, where men are affected by physical and quality loss and women absorb market loss. Following steps 1-3 can inform and identify upgrades that are gender-neutral or gender-specific. In step 3, designing upgrades that improve preservation of fish (e.g. smoking, freezing) may extend shelf-life, improve storage capacity and contribute to food security objectives by preserving nutritional value of 
fish and avoid loss of nutrients. Based on a study by Kawarazuka \& Béné (2011), the nutritional value of small pelagics species such as anchovy, herring and mackerel is generally higher than other animal and plant-source foods. Therefore, designing upgrades that improve preservation of small pelagics species is the focus of chapter 3 . Improved preservation techniques can facilitate distribution, transportation, and sales of fish from the coast to non-coastal areas. In Ghana, for example, smoked fish is consumed as far as $600 \mathrm{~km}$ inland and traded beyond its borders with Burkina Faso (Kawarazuka \& Béné, 2011). Longer storage capacity provides protein to households during lean seasons, or when fish is out of season.

\section{Cross-cutting Themes of the Framework}

Within the value chain upgrading framework are important cross-cutting themes that warrant closer attention because of their direct relationship to small-scale fisheries and their broader contribution within the social-ecological system. Themes presented but not limited to the framework are food security, gender and biodiversity. They are subsequently discussed.

\section{Gender}

Men are often associated with fishing; however, women are believed to represent 47 percent of the fisheries workforce in developing countries (Pomeroy \& Andrew, 2011). Despite this significant figure, their roles and contribution within this sector is often poorly understood. Women occupy key roles in the post-harvest sector (Harper, Zeller, Hauzer, Pauly, \& Sumaila, 2013). They are primarily involved in processing and marketing activities, although in some places such as Ghana, women also finance fishing trips (Weerantunge, Snyder, \& Sze, 2010). Through these 
activities, women generate income and provide food to their families. They also have important and technical know-how of fisheries and possess local ecological knowledge (Calhoun, Conway, \& Russell, 2016). Men and women experience the environment from different perspectives, as a result, they also perceive threats to it differently (Santos, 2015). Therefore, women's knowledge of fisheries is very useful in designing and implementing post-harvest innovations. Their participation, however, can be limited due lack of time and reproductive responsibilities and constrained by illiteracy or social norms (Matsue, Daw, \& Garrett, 2014). As a tool, a gender analysis explains roles of men and women in the fisheries value chain and the reasons behind those roles. Understanding these roles through a gender lens is important from the design stage to scale. For example, is the type of upgrade (e.g. machinery or equipment) suitable for its user? Are trainings tailored to the needs and skills by gender? These are just a few questions to consider when diffusing an innovation so that men and women have equal opportunity to participate and benefit from it.

\section{Food security}

Food security ${ }^{10}$ is an important cross-cutting theme of value chain improvements in developing countries. The United Nations (2012) urges countries to effectively manage fisheries to help ensure food security. The Millennium Development Goals recognize the importance of fisheries to achieving their objectives, including eradicating hunger (Heck, Béné \& Reyes-Gaskin, 2007). The primary objectives of Feed the Future, the U.S. Government's Global Hunger and

\footnotetext{
${ }^{10}$ Defined "when all people, at all times, have physical and economic access to sufficient, safe and nutritious food to meet their dietary needs and food preferences for an active and healthy life” (World Food Summit, 13-17 November, 1996).
} 
Global Food Security Initiative is to improve people's nutritional status, particularly that of women and young children (USAID, 2011). Food security goals need to be taken into consideration when post-harvest value chain improvements are introduced. Food security is particularly important for developing countries that are highly dependent on fish as an affordable source of protein (Golden, Allison, Cheung, Dey, Halpern, McCauley... \& Myers, 2016). These countries often cannot replace loss of nutrients as easily as wealthier countries who can substitute the loss of domestic production with imports (Golden et al., 2016). Before implementing improvements within the value chain, it is important to evaluate the potential to boost or undermine food security within that context. For example, technical interventions that increase efficiency such as more powerful outboard engines or more durable gear may increase income in the short-term but ultimately may have a negative impact on fishery resources in the absence of management (Allison \& Ellis, 2001). Likewise, capitalintensive interventions can lead to increased fishing effort and comprise resource sustainability if users are unable to earn sufficient returns on the investment (Allison \& Ellis, 2001). Interventions that lead to over-exploitation of fisheries can undermine food security. The impact of trade on food security is an ongoing debate that is further explored in chapter 2.

\section{Biodiversity}

Biodiversity is increasingly under threat due to various causes. Murawski, Methot, \& Tromble (2007) discuss biodiversity as it relates to fisheries in terms of stock abundance and species diversity. In this context, threats to marine biodiversity include overfishing, destructive fishing gears, and use of illegal fishing practices 
(Pauly \& Watson, 2003). A discussion of these causes is beyond the scope of this paper. Yet, innovations in commercial fishing technology, such as gear types, are partly to blame for these causes (Pauly \& Watson, 2003). Small-scale fisheries are known to employ relatively low technology and simple gear types (WorldFish, 2008). Regardless of their sophistication, they can still destroy and degrade the environment. For example, in Ghana illegal small mesh size nets are known to be used to catch juvenile fish. This can have negative impacts on the ecosystem by shortening the food web, a phenomenon discussed by Pauly and Watson (2003).

Mangrove depletion and deforestation from anthropogenic sources also threaten biodiversity. Causes for mangrove depletion in fisheries are demand for fuel wood and clearing for aquaculture development (Evangelista, 1992). Fuelwood is an important source of energy for cooking and heating in sub-Saharan Africa. Between 1980 and 2005, it accounted for over 70 percent of the total energy use, followed by petroleum and electricity, respectively (Kebede, Kagochi, \& Jolly, 2010). Since then, Africa has recorded one of the highest annual net losses of forests (FAO, 2015). Continued reliance of fuel wood contributes to loss in biodiversity (FAO, 2015). Similar to fish, loss of trees used for fuel wood can also be evaluated using the framework presented in Figure 1.1 to inform the design of interventions that regenerate this resource. Innovative technologies that reduce consumption of fuelwood for smoking fish are discussed in chapter 3.

Many of these causes that lead to loss of biodiversity result from poor management of natural resources. Therefore, it is important to design and implement value chain upgrades that align with and do not detract from sustainable fishery and 
terrestrial management objectives or tenure arrangements. Implementing value chain improvements in fisheries that are engaged in some form of fishery improvement project is recommended to minimize negative impacts or control for unintended consequences.

The value chain upgrading framework (Figure 1.1) is designed based on existing value chain, post-harvest loss and extension frameworks as well as the experience conducting primary research related to value chain improvements in West Africa. Results of this research are discussed in chapter 2 and 3. Each chapter contributes to this framework in slightly different ways. Chapter 2 relates to step two and three of the framework. Chapter 2 assesses post-harvest loss of sole in The Gambia and designs an intervention to reduce it. Chapter 3 relates to step four of the framework. Chapter 3 measures adoption of improved fish smoking technology in Ghana. Chapter 4 summarizes and discusses results of research questions as they pertain to two case studies in West Africa.

\section{Discussion}

Value chain research informs production and trade of products we consume daily. Typically, the VCA is used by industrial manufacturers to make clothes we wear and food we eat presumably better for less money. Increasingly, this approach is applied to fisheries. So far, it seems to offer new perspectives on relationships and links among networks of people, or nodes, along the chain. The VCA may help identify opportunities to upgrade or improve a node's position along the chain through post-harvest innovations. Upgrading small-scale fisheries in developing countries is a 
relatively new area of focus in value chain research based on review of the literature. Particular types of innovations that upgrade certain networks of people are discussed.

O’Neill and Crona (2017) and Rosales et al. (2017) use the VCA to increase our understanding of distribution of economic benefits by node along the chain. Rosales et al. (2017) conduct value chain studies in eight small-scale fisheries in the Philippines and conclude fishers are price takers or take what they can get. In this study, fishers earn the lowest profit margin among all actors in the chain (Rosales et al., 2017). Personal experience serves as a reminder that commercial harvesters (e.g. fishers) in capture fisheries have to sell what they catch and soon, often at prices dictated by others. In aquaculture there is more room to maneuver in this respect, for example, one can schedule a harvest around favorable market conditions, which is not a guarantee (of better prices), but at least an option.

Rosales et al. (2017) propose upgrades, ${ }^{11}$ or improvements in fish quality that enhance value so primary harvesters "get a fairer share of the total economic value of their catch” (Rosales et al., 2017, p.21). One example of increasing the economic value of a fisher's catch is through improved processing techniques on-board (e.g. ice) or improved storage facilities available to fishers that minimize post-harvest quality loss or rejection due to quality by buyers or others along the chain (Rosales et al., 2017). This is a potential example of upgrading a node-comprised of primary harvesters-through improvements aimed to enhance the value of their catch. Where possible, it is important to account for the impact that upgrading one node has on another node. Evidence of this is further discussed in Chapter 2.

${ }^{11}$ Specific mention to ice plants and cold storage facilities. 
O’Neill and Crona (2017) use the VCA to identify and highlight the role of women along the chain. This awareness leads to questions about marginalization (of certain actors) in fishery development projects. The conceptual framework in Figure 1.1 aims to prevent marginalization or displacement of both men and women in postharvest development projects. For example, Chapter 2 focuses on upgrading a node dominated by men but simultaneously assesses impact on another node (and market) dominated by women. Chapter 3 focuses on innovations that attempt to upgrade a node dominated by women with the aim of benefitting others along the chain.

There are many factors to consider when upgrading a node beginning with the type of innovation. An innovation is typically characterized by its newness; however, it must satisfy a need with some degree of benefit in order for it to be adopted (Rogers, 1995). Diffusion theory is largely informed by agricultural innovations. Ryan and Gross (1943) and Deutschmann and Fals Borda (1962) are seminal studies of innovations that aim to increase productivity among farmers in the North and South. In the Midwest, farmer nodes benefitted economically from an innovation (e.g. hybrid corn seed) that increased corn yields (Ryan \& Gross, 1943). The Deutschmann and Fals Borda study (1962) took place in a different context but produced similar results by diffusing a new potato variety among Andean farmers. These are hailed as success stories, yet notable failures exist. One example of failure discussed by Rogers (1995) is how tomato harvesters in California were displaced with the introduction of improved machinery. In this case, the innovation not only adversely impacted the processing node (by eliminating jobs) but also produced tomatoes consumers 
rejected. ${ }^{12}$ Similar to this dissertation, innovations discussed in these studies center around nodes closest to the resource they harvest or extract.

Innovations come with uncertainty and perceived risk (Rogers, 1995). Risk and uncertainty affect people differently. The relative strength of a node with respect to financial investments is a relevant topic in small-scale developing world fisheries. Fishing is often characterized as an occupation of last resort for the poorest of the poor (Allison \& Ellis, 2001; Fauzi \& Zuzy, 2010). Empirical studies conducted by Pollnac \& Poggie (2006) in North America and by Pollnac, Pomeroy and Harkes (2001) in Southeast Asia demonstrate fishing is a desirable and satisfying occupation despite risk and uncertainty with respect to variability of catch. Personal experience also challenges this assumption but recognizes evidence that suggest primary harvesters earn low margins. Therefore, upgrading nodes closest to the resource they depend on drives this research.

Finally, fisheries innovations should not be confused with incentives that lead to overexploitation. This research is mindful of unintended consequences that result from technological innovations regardless of their degree of sophistication. Controls within this framework are intended to avoid adverse impacts potentially caused by innovations on its users, others along the chain and the environment, but places no guarantee.

\section{Conclusion}

This chapter introduced the concept of upgrading nodes through post-harvest innovations using a conceptual framework. The framework shown in Figure 1.1 was

${ }^{12}$ To facilitate machine-picking, scientists bred hard tomatoes so they would not easily bruise during harvest (Rogers, 1995). 
partly shaped by the research presented in chapters 2 and 3. The framework also accounts for important cross-cutting themes relevant to the context in which these fisheries operate. Through the learning and adaptation process this framework may lead to wider application, or beyond types of innovations and nodes discussed in this dissertation. Upgrade opportunities are not limited to technological innovations discussed in this dissertation. Value chain research points to other market and management measures, such as certification and financing schemes and collective action ${ }^{13}$ as ways to upgrade nodes along the chain.

${ }^{13}$ A node within the chain may be able to leverage their position through collective action. A fishing cooperative is an example of collective action relevant to fisheries (Uchida, 2017). It's success, however, depends on various enabling conditions including membership, exclusion method and privileged group outlined by Uchida (2017). 


\section{Appendix A}

Analytic process for addressing research questions in this dissertation (Figure adapted from Rummel, 1970). 


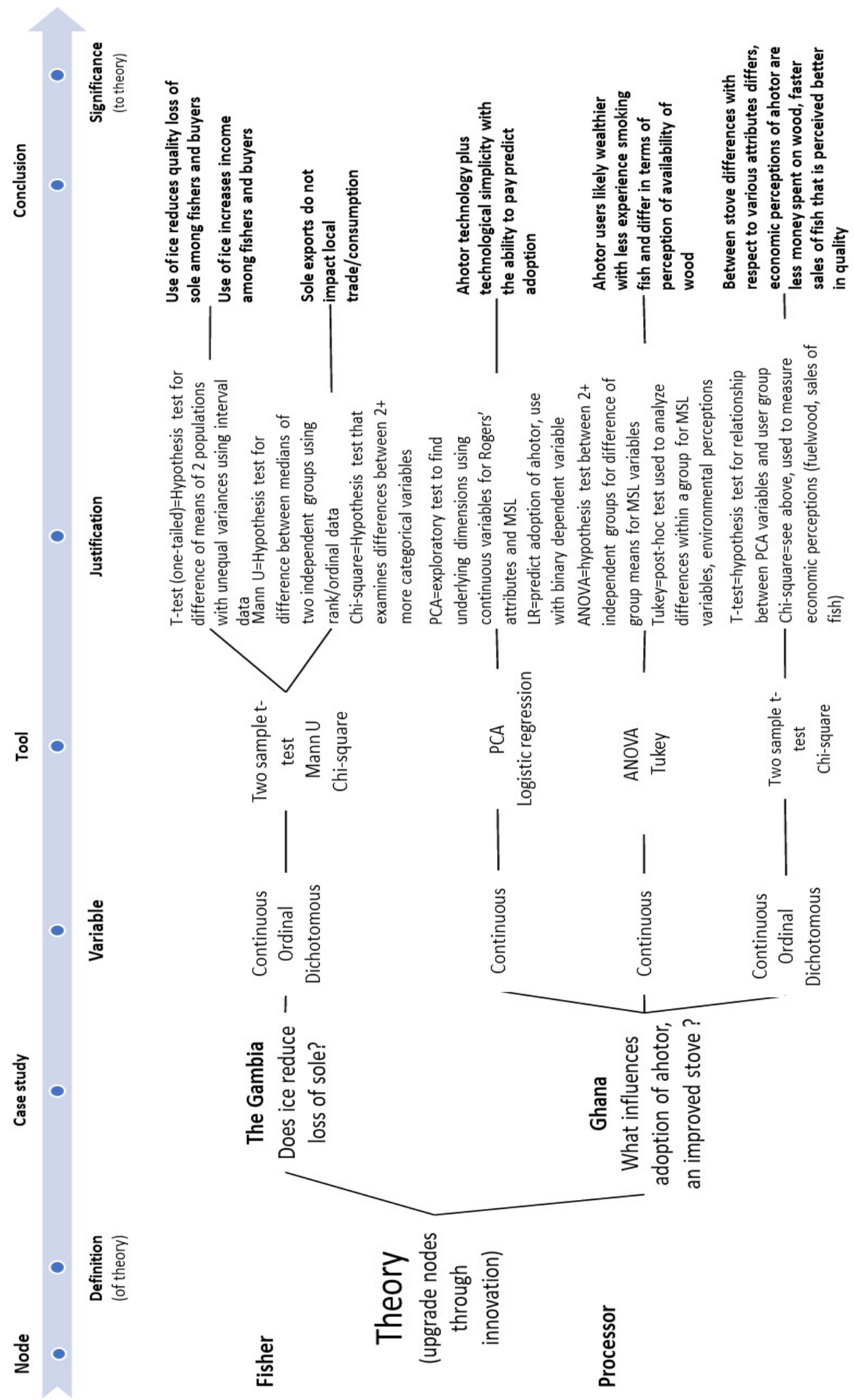




\section{References}

Affognon, H., Mutungi, C., Sanginga, P., \& Borgemeister, C. (2015). Unpacking Postharvest losses in sub-Saharan Africa: A meta-analysis. World Development, 66, 49-68.

Akande, G., \& Diei-Ouadi, Y. (2010). Post-harvest Losses in Small-scale Fisheries: Case Studies in Five sub-Saharan African Countries. FAO Fisheries and Aquaculture Technical Paper, (550). 77pp.

Allison, E. H., \& Ellis, F. (2001). The Livelihoods Approach and Management of Small-scale Fisheries. Marine Policy, 25(5), 377-388.

Asche, F., Bellemare, M. F., Roheim, C., Smith, M. D., \& Tveteras, S. (2015). Fair Enough? Food Security and the International Trade of Seafood. World Development, 67, 151-160.

Bair, J. (2008). Analysing Global Economic Organization: Embedded Networks and Global Chains Compared. Economy and Society, 37(3), 339-364.

Barrientos, S., Gereffi, G., \& Rossi, A. (2011). Economic and Social Upgrading in Global Production Networks: A New Paradigm for a Changing World. International Labour Review, 150(3-4), 319-340.

Béné, C., \& Heck, S. (2005). Fish and Food Security in Africa. NAGA, WorldFish Center Quarterly, 28(3-4), 8-13.

Borda, O. F., \& Deutschmann, P. (1962). Communication and Adoption Patterns in an Andean Village. San Jose, Costa Rica, Programa Interamericano De Informacion Popular.

Calhoun, S., Conway, F., \& Russell, S. (2016). Acknowledging the Voice of Women: Implications for Fisheries Management and Policy. Marine Policy, 74, 292299.

Cheke, R. A., \& Ward, A. (1998). A Model for Evaluating Interventions Designed to Reduce Post-Harvest Fish Losses. Fisheries Research, 35(3), 219-227.

Cooksey, K. (2014). Modified Atmosphere Packaging of Meat, Poultry and Fish. Innovations in Food Packaging (second edition), pp. 475-493.

Crawford, B., Gonzales, L., Amin, D., Nyari-Hardi, B., \& Sarpong, Y. (2016). Report on the Baseline Survey of Small Pelagic Fishing Households along the Ghana Coast. The USAID/Ghana Sustainable Fisheries Management Project (SFMP) Narragansett, RI: Coastal Resources Center, Graduate School of Oceanography, University of Rhode Island.GH2014_PGM187_CRC.122pp.

Crawford, B., Herrera, M. D., Hernandez, N., Leclair, C. R., Jiddawi, N., Masumbuko, S., \& Haws, M. (2010). Small scale Fisheries Management: Lessons from Cockle Harvesters in Nicaragua and Tanzania. Coastal Management, 38(3), 195-215. 
Da Silva, D. (2011). Value Chain of Fish and Fishery Products: Origin, Functions and Application in Developed and Developing Country Markets. Food and Agriculture Organization. 63pp.

De Marchi, V. D., Maria, E. D., \& Micelli, S. (2013). Environmental Strategies, Upgrading and Competitive Advantage in Global Value Chains. Business Strategy and the Environment, 22(1), 62-72.

Demont, M., \& Ndour, M. (2015). Upgrading Rice Value Chains: Experimental Evidence from Eleven African Markets. Global Food Security, 5, 70-76.

Evangelista, D. (1992). Management of Mangrove Areas in Calauag Bay, Quezon Province, Philippines. WorldFish Centre. Http://agris.fao.org/agrissearch/search.do?recordID=QW2012000945

Fabinyi, M. (2016). Producing for Chinese Luxury Seafood Value Chains: Different Outcomes for Producers in the Philippines and North America. Marine Policy, 63, 184-190.

Fauzi, A., \& Zuzy, A. (2010). Social Resilience and Uncertainties: The Case of Smallscale Fishing Households in the North Coast of Central Java. Mast, 9(2), 5564.

Food and Agriculture Organization of the United Nations (FAO). (2008). Many of the World's Poorest People Depend on Fish. Retrieved from http://www.fao.org/Newsroom/en/news/2005/102911/index.html

Food and Agriculture Organization of the United Nations (FAO). (2014). The State of Fisheries and Aquaculture. Opportunities and Challenges. ( No. E-ISBN 97892-5-108276-8). Rome: FAO. Retrieved from http://www.fao.org/3/ai3720e.pdf.

Food and Agriculture Organization of the United Nations (FAO). (2015). The Global Forest Resources Assessment. ( No. ISBN-978-92-5-108826-5). Rome: FAO. Retrieved from http://www.fao.org/3/a-i4808e.pdf.

Food and Agriculture Organization of the United Nations (FAO). (2018). Fisheries and Aquaculture Department. People and Communities. Retrieved from http://www.fao.org/fishery/ssf/people/en.

Gereffi, G. (1999). International Trade and Industrial Upgrading in the Apparel Commodity Chain. Journal of International Economics, 48(1), 37-70.

Gereffi, G., \& Fernandez-Stark, K. (2016). Global Value Chain Analysis: A Primer. Second Edition. Duke University. Center on Globalization, Governance \& Competitiveness at the Social Science Research Institute.

Gereffi, G., Humphrey, J., \& Sturgeon, T. (2005). The Governance of Global Value Chains. Review of International Political Economy, 12(1), 78-104.

Golden, C., Allison, E. H., Cheung, W. W., Dey, M. M., Halpern, B. S., McCauley, D. J., . . . Myers, S. S. (2016). Fall in Fish Catch Threatens Human Health. Nature, 534(7607), 317-320. 
Hamilton-Hart, N., \& Stringer, C. (2016). Upgrading and Exploitation in the Fishing Industry: Contributions of Value Chain Analysis. Marine Policy, 63, 166-171.

Hara, M. M. (2014). Analysis of South African Commercial Traditional Linefish Snoek Value Chain. Marine Resource Economics, 29(3), 279-299.

Harper, S., Zeller, D., Hauzer, M., Pauly, D., \& Sumaila, U. R. (2013). Women and Fisheries: Contribution to Food Security and Local Economies. Marine Policy, 39, 56-63.

Heck, S., Béné, C., \& Reyes-Gaskin, R. 2007. Investing in African fisheries: Building Links to the Millennium Development Goals. Fish and Fisheries, 8(3), 211226.

Huss, H. H. (1988). Fresh fish quality and quality changes: A Training Manual Prepared for the FAO/DANIDA Training Programme on Fish Technology and Quality Control. Food \& Agriculture Organization.

Kabahenda, M., Omony, P., \& Hüsken, S. (2009). Post-Harvest Handling of Lowvalue Fish Products and Threats to Nutritional Quality: A Review of Practices in the Lake Victoria Region. Fisheries and HIV/AIDS in Africa: Investing in Sustainable Solutions, the WorldFish Center.

Kaplinsky, R. (2000). Globalisation and unequalisation: What Can Be Learned from Value Chain Analysis? Journal of Development Studies, 37(2), 117-146.

Kaplinsky, R., \& Morris, M. (2000). A Handbook for Value Chain Research. University of Sussex, Institute of Development Studies.

Kawarazuka, N., \& Béné, C. (2011). The Potential Role of Small Fish Species in Improving Micronutrient Deficiencies in Developing Countries: Building Evidence. Public Health Nutrition, 14(11), 1927-1938.

Kebede, E., Kagochi, J., \& Jolly, C. M. (2010). Energy Consumption and Economic Development in sub-Saharan Africa. Energy Economics, 32(3), 532-537.

Kelleher, K. (2005). Discards in the World's Marine Fisheries: An Update Food \& Agriculture Organization. Rome.

LaGra, J. (1990). A Commodity Systems Assessment Methodology for Problem and Project Identification. A Commodity Systems Assessment Methodology for Problem and Project Identification. A Post-Harvest Loss Assessment. http://ucanr.edu/datastoreFiles/234-1319.pdf.

Matsue, N., Daw, T., \& Garrett, L. (2014). Women Fish Traders on the Kenyan Coast: Livelihoods, Bargaining Power, and Participation in Management. Coastal Management, 42(6), 531-554.

Murawski, S., Methot, R., \& Tromble, G. (2007). Biodiversity Loss in the Ocean: How Bad Is It? Science (New York, N.Y.), 1281-4, DOI:316/5829/1281b [pii].

Neiland, A. E., \& Béné, C. (2013). Poverty and Small-scale Fisheries in West Africa. Springer Science \& Business Media. 
O'Neill, E. D., \& Crona, B. (2017). Assistance Networks in Seafood Trade: A Means to Assess Benefit Distribution in Small-scale Fisheries. Marine Policy, 78, 196-205.

Parry, R. (2012). Principles and Applications of Modified Atmosphere Packaging of Foods. Springer Science \& Business Media.

Pauly, D., \& Watson, R. (2003). Counting the Last Fish. Scientific American, 289(1), 42-47.

Pietrobelli, C., \& Rabellotti, R. (2011). Global Value Chains Meet Innovation Systems: Are There Learning Opportunities for Developing Countries? World Development, 39(7), 1261-1269.

Pollnac, R. B., \& Poggie Jr, J. J. (2006). Job Satisfaction in the Fishery in Two Southeast Alaskan Towns. Human Organization, , 329-339.

Pollnac, R. B., Pomeroy, R. S., \& Harkes, I. H. (2001). Fishery Policy and Job Satisfaction in Three Southeast Asian Fisheries. Ocean \& Coastal Management, 44(7-8), 531-544.

Pomeroy, R. S., \& Andrew, N. (2011). Small-scale Fisheries Management: Frameworks and Approaches for the Developing World. Oxfordshire, UK and Cambridge, MA: Cabi.

Ponte, S., Kelling, I., Jespersen, K. S., \& Kruijssen, F. (2014). The Blue Revolution in Asia: Upgrading and Governance in Aquaculture Value Chains. World Development, 64, 52-64.

Porter, M. E. (1985). Competitive Advantage: Creating and Sustaining Superior Performance. 1985.

Porter, M. E. (1998). Clusters and the New Economics of Competition. Harvard Business Review Boston.

Purcell, S. W., Crona, B. I., Lalavanua, W., \& Eriksson, H. (2017). Distribution of Economic Returns in Small-scale Fisheries for International Markets: A ValueChain Analysis. Marine Policy, 86, 9-16.

Riisgaard, L., Bolwig, S., Ponte, S., Du Toit, A., Halberg, N., \& Matose, F. (2010). Integrating Poverty and Environmental Concerns into Value-Chain Analysis: A Strategic Framework and Practical Guide. Development Policy Review, 28(2), 195-216.

Rogers E. M. (1995). Diffusion of innovations (fourth edition). The Free Press. New York.

Rosales, R. M., Pomeroy, R., Calabio, I. J., Batong, M., Cedo, K., Escara, N., . . . Sarahadil, M. (2017). Value Chain Analysis and Small-scale Fisheries Management. Marine Policy, 83, 11-21.

Rummel, R. J. (1970). Applied Factor Analysis. Northwestern University Press. Evanston. 
Ryan, B., \& Gross, N. C. (1943). The Diffusion of Hybrid Seed Corn in Two Iowa Communities. Rural Sociology, 8(1), 15.

Santos, A. N. (2015). Fisheries as a way of life: Gendered Livelihoods, Identities and Perspectives of Artisanal Fisheries in Eastern Brazil. Marine Policy, 62, 279288.

Uchida, H. (2017). TURFs, Collective Fishery Management, and Fishery Cooperatives. Bulletin of Marine Science, 93(1), 83-99.

USAID. 2011. Feed the Future FY 2011-2015 Multi-year Strategy. U.S. Government Document Approved February 22, 2011.

http://www.feedthefuture.gov/sites/default/files/country/strategies/files/Ghana FeedtheFutureMulti-YearStrategy 2011-08-03.pdf .

Ward, A., \& Jeffries, D. (2000). A Manual for Assessing Post-Harvest Fisheries Losses. Overseas Development Administration. Natural Resources Institute. University of Greenwich.

Washington, S. (2009). Private Standards in Fisheries and Aquaculture: Current Practice and Emerging Issues. GLOBEFISH Research Programme, 97, I.

Weerantunge, N., Snyder, K. A., \& Sze, C. P. (2010). Gleaner, Fisher, Trader, Processor: Understanding Gendered Employment in Fisheries and Aquaculture. Fish and Fisheries, 11(4), 405-420.

Wentink, C. R., Raemaekers, S., \& Bush, S. R. (2017). Co-governance and Upgrading in the South African Small-scale Fisheries Value Chain. Maritime Studies, 16(1), 5.

WorldFish Center. (2008). Small-scale Capture Fisheries: A Global Overview with Emphasis on Developing Countries: A Preliminary Report of the Big Numbers Project. The WorldFish Center Working Papers.

World Food Summit. (1998). Conference on Attaining the World Food Summit's Objectives Through a Sustainable Development Strategy Following the Plan of Action at the World Food Summit in 1996. Rome. http://archive.ipu.org/splze/rome98.htm. 


\title{
Chapter 2
}

\section{IMPLEMENTING A VALUE CHAIN IMPROVEMENT IN THE GAMBIAN SOLE FISHERY: CONSEQUENTIAL IMPACTS ON FISHERY STAKEHOLDERS}

\author{
by \\ Kristine Beran ${ }^{1}$, Richard B. Pollnac ${ }^{2}$, Elin C. Torell ${ }^{3}$
}

Submitted to Marine Policy

\footnotetext{
${ }^{1} \mathrm{PhD}$ Candidate, Department of Marine Affairs, University of Rhode Island, RI, 02881, USA, Email: Kristine_beran@uri.edu.

${ }^{2}$ Research Professor, Department of Marine Affairs, University of Rhode Island, RI, 02881, USA, Email: Pollnac3@gmail.com.

${ }^{3}$ Adjunct Professor, Department of Marine Affairs, University of Rhode Island and Director of International Programs, Coastal Resources Center, University of Rhode Island Graduate School of Oceanography, Narragansett, RI, 02882, USA, Email: ElinTorell@uri.edu.
} 


\begin{abstract}
Small-scale tropical fisheries suffer from significant post-harvest losses. This study applies the value chain and post-harvest loss assessment approach to identify where and how much sole is subject to post-harvest loss along the supply chain in The Gambia. Value chain improvement interventions, ice and ice coolers are introduced on-board fishing vessels to reduce quality-related losses. The study reveals ice reduces loss and increases revenue for some, not all value chain actors. Overall, fishermen using ice on-board lost 14 percent less sole than fishermen not using ice. The cost of ice; however, exceeded the difference in revenue earned on average. Hence, there is no economic incentive for fishermen to purchase ice at the current market price just for sole. Fishermen's use of ice on-board fishing vessels had a statistically significant positive impact on the buyer's loss of sole, which became less than one percent. As a result, a buyer's revenue nearly doubled on average during the study period. This leads to the conclusion that post-harvest loss of fish can be reduced in tropical developing world small-scale fisheries, however, the cost may exceed the benefit for fishermen. This study also confirmed that, in the case of the Gambian sole fishery, value chain improvements benefiting the export supply chain does not affect the local market. Keywords: Value chain, post-harvest loss, small-scale fisheries, fishery improvement projects (FIPs)
\end{abstract}




\section{Introduction}

Small-scale fisheries around the world are increasingly recognized for their contribution to food security and poverty alleviation (Akande \& Diei-Ouadi, 2010; Food and Agricultural Organization of the United Nations [FAO], 2014; Pomeroy \& Andrew, 2011), yet high levels of post-harvest loss within small-scale fisheries prevent optimal utilization of natural resources (Akande \& Diei-Ouadi, 2010). The value chain approach was developed to identify where along the supply chain opportunities exist to maximize value, or profit from products, services or raw materials in a system (Harland, 1996; Porter, 1985). The value chain concept was popularized by Michael Porter to help corporations compete more effectively and maximize returns on investment (Porter, 1985). The value chain concept focuses on the social distribution of economic growth and the application of this framework is gaining recognition within development circles and marine policy (Pomeroy \& Andrew, 2011; Macfadyen, Nasr-Alla, Al-Kenawy, Fathi, Hebicha, Diab, Hussein, Abou-Zeid \& El-Naggar, 2012; Hamilton-Hart \& Stringer, 2016). Both Hempel (2010) and Pomeroy and Andrew (2011) apply the value chain concept to small-scale fisheries operating in a developing world context. Pomeroy and Andrew (2011) stress that small-scale fisheries in developing countries often fail to capture value due to quality standards and poor product-holding infrastructure among other constraints. As the supply of fish from developing countries to the international market increases according to the FAO (2014), greater attention to quality standards may be warranted.

Small-scale fisheries in developing countries generate most of the world's fish landings, yet are highly susceptible to post-harvest quality losses, ranging between 20 
to 75 percent (FAO, 2014). Post-harvest losses lead to reductions in the quantity, quality, monetary and/or nutritional value of fish (FAO, 2014). The term post-harvest refers to the period of time from when a fish is separated from its growth medium (Morrissey, 1988; Ward \& Jeffries, 2000), including the moment a fish is captured in a net, caught on a hook or in a trap (Ward \& Jeffries, 2000). The causes of post-harvest loss vary from poor hygiene, handling and storage at-sea, on-board, and on shore (Pomeroy \& Andrew, 2011).

Small-scale fishermen and processors in developing countries rarely discard fish. Rather, their harvest is subject to quality and monetary loss, or foregone revenue due to poor handling and inefficient processing techniques (Akande \& Diei-Ouadi, 2010). The type of loss discussed in this paper relates to quality, or difference between export and domestic grade quality sole, which in turn is reflected by differences in market price. All things being equal, fish subjected to deterioration or mishandling is often sold at a lower or reduced price, not achieving its potential value in the market. Economic calculations are based on loss in revenue due to quality captured at various points along the supply chain (Ward \& Jeffries, 2000).

Trends in losses vary across the entire fish supply chain and often are neither quantified nor precisely defined (Akande \& Diei-Ouadi, 2010). In the Philippines, eight value chain studies among small-scale fisheries with domestic and export markets showed that in general fishermen capture the least profit among actors in those value chains (Rosales, Pomeroy, Calabio, Batong, Cedo, Escara, Facunla, Gulayan, Narvadez, Sarahadil \& Sobrevega, 2017). This paper examines the impacts of a value chain improvement intervention that used ice and ice boxes, or coolers on- 
board artisanal canoes on post-harvest quality loss of export-oriented sole in The Gambia. The study combines elements of the value chain approach (Porter, 1985, Gereffi \& Fernandez-Stark, 2011, Kaplinsky, 2000; Kaplinsky \& Morris, 2001) and the United Nations Food and Agricultural Organization's (FAO) post-harvest loss assessment approach (Akande \& Diei-Ouadi, 2010) to determine where losses occur along the chain, who benefits, and where potential entry points for economic gains in small-scale tropical fisheries exist.

The questions this study addresses are 1) does the use of ice on-board fishing vessels reduce fishermen's post-harvest quality loss of sole; 2) do reductions in postharvest loss lead to an increase in fishermen's revenue from sole; 3) does purchasing iced sole from fishermen reduce buyer's post-harvest quality loss; 4) do reductions in post-harvest loss increase buyer's revenue from sole purchases; and 5) does sole have economic importance to local processors. Sole is almost exclusively harvested for export. The term export loss is introduced in this study to define product which does not meet export quality standards and fails to achieve significant export trade earnings. Export revenues from fish trade contribute to national and local economies in developing countries (Bostock, Greenhalgh \& Kleih, 2004), however, there is an argument that wealth generated through trade does not necessarily trickle down to those extracting resources (Béné, Lawton \& Allison, 2010). This study differs from recent value chain studies in small-scale fisheries in developing countries because it considers the impact of an export-oriented value chain improvement on local trade and consumption of sole. 


\section{The Gambian Sole Fishery}

The Gambia is a small coastal country surrounded by the Republic of Senegal on three sides. Like Senegal, it is situated in the highly productive upwelling zone of the Canary Current Large Marine Ecosystem (CCLME) and benefits from cold, nutrient rich waters. The CCLME flows southward from the Canary Islands and Morocco, reaching the Senegambia plateau in March and April. This coincides with the peak season for landings of many commercial fish species, including sole (Fafanding, Tobey \& Drammeh, 2010). Fishing is a major source of food and employment in The Gambia (Belhabib, Asberr, Zeller, \& Pauly, 2013). Small-scale fisheries account for the majority of fish landed and contribute significantly to income generation, exports and food security for coastal communities where most Gambians live (Belhabib et al., 2013).

Sole is commercially processed to export specifications and shipped frozen on container ships to markets within the European Union, South Africa and Asia (The Gambia Department of Fisheries [DoFish], 2015; R. Eenennaam, personal communication, October 23, 2017). Sole which does not meet export-quality standards, determined by organoleptic and bacteriologic specifications (including temperature of fish upon delivery to the export processing plant), is purchased at a lower ex-vessel price by local fish processors. Local fish processors smoke, dry or salt fish to preserve and sell for domestic consumption. Ninety-nine percent of all sole exports are shipped frozen (R. Eenennaam, personal communication, October 23, 2017). Eight-five percent of exports are processed as value-added fillets and the balance is exported as whole, head-on fish. The proportions are likely to shift in the coming years given the growing demand for whole, head-on sole from China and 
because it requires less labor to process (R. Eenennaam, personal communication, October 23, 2017).

\section{A Management and Market in Transition}

Prior to 2008, the Gambian sole fishery operated as a de facto open access fishery with little to no management measures in place (United States Agency for International Development BaNafaa Project [USAID/BaNafaa], 2014). Since then, various fisheries improvement projects have been implemented to improve ecological productivity and market access through market-based approaches and collective, rights-based fisheries management. These improvement projects resulted in a comanagement plan and a fisheries improvement project (FIP) work plan for sole (Fishery Co-Management Plan for The Gambia Sole Complex, 2012).

The co-management plan, adopted by stakeholders in 2012 and as law in 2013, declares a special management area from shore out to nine nautical miles (Fishery CoManagement Plan for The Gambia Sole Complex, 2012). It also grants communitybased management institutions, the National Sole Fishery Co-Management Committee (NASCOM) and currently nine Landing Site Co-management Committees (LACOMs), territorial use-rights and management responsibilities for sole and marine catfish to these groups in this area (Fishery Co-Management Plan for The Gambia Sole Complex, 2012). Currently, this fishery remains open, managed access and input measures such as closed areas, seasons, minimum sizes, and gear restrictions are used to regulate it (USAID/BaNafaa, 2014). The co-management governance structure is illustrated in Figure 2.1. The function of the governance structure in Figure 2.1 is to 
jointly manage the sole fishery from shore to nine nautical miles in accordance with the Fishery Co-Management Plan for The Gambia Sole Complex (2012).

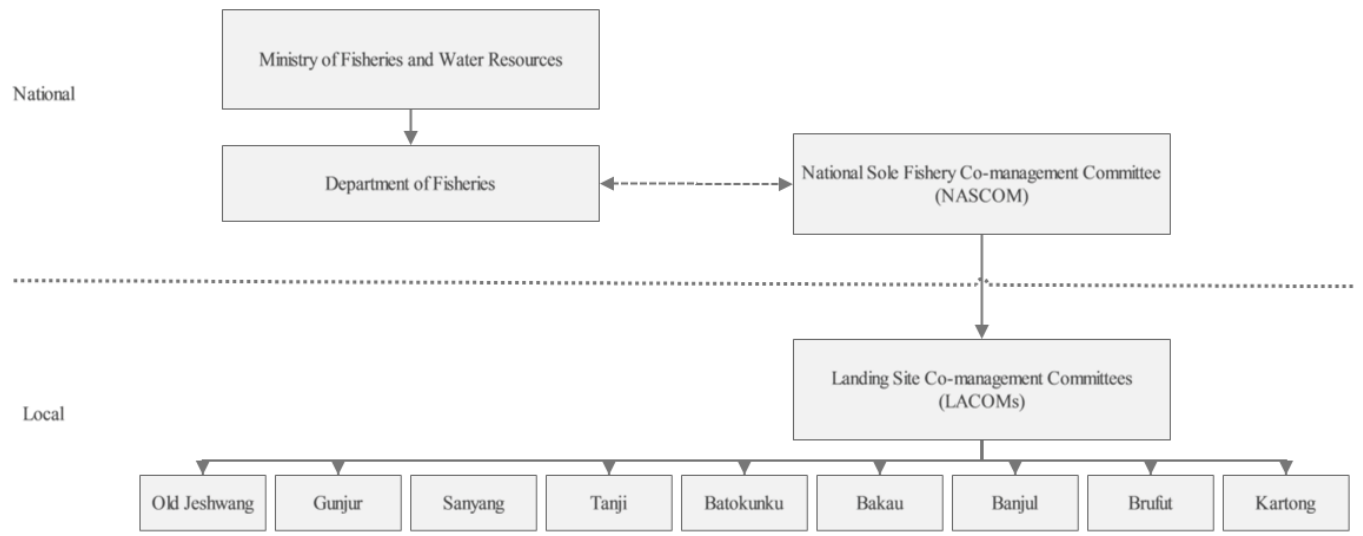

Figure 2.1. Governance structure for the sole fishery in The Gambia

A combination of management and market-based incentives in the Gambian sole fishery demonstrates sustained engagement among multiple stakeholders in the supply chain.

Table 2.1. Fisheries improvement projects in the Gambian sole fishery.

\begin{tabular}{|c|c|c|c|}
\hline Year & $\begin{array}{c}\text { Lead agency } \\
\text { (Implementing partners) }\end{array}$ & Donor & Major activities \\
\hline 2008 & $\begin{array}{l}\text { Gambian Artisanal Fisheries } \\
\text { Development Association }\end{array}$ & $\begin{array}{l}\text { Marine Stewardship } \\
\text { Council (MSC) }\end{array}$ & MSC pre-assessment \\
\hline 2009-2014 & $\begin{array}{l}\text { University of Rhode Island } \\
\text { (Worldwide Fund for Nature, } \\
\text { Department of Fisheries) }\end{array}$ & $\begin{array}{l}\text { United States Agency for } \\
\text { International } \\
\text { Development (USAID) }\end{array}$ & $\begin{array}{c}\text { Co-management committees and } \\
\text { plan } \\
\text { Data collection } \\
\text { Stock assessment } \\
\text { Value chain analysis } \\
\text { Fishery Performance Indicators }\end{array}$ \\
\hline 2015 & $\begin{array}{l}\text { National Sole Fishery Co- } \\
\text { management Committee }\end{array}$ & $\begin{array}{c}\text { Resources Legacy } \\
\text { Fund/Sustainable } \\
\text { Fisheries Fund }\end{array}$ & MSC pre-assessment \\
\hline 2015-2016 & $\begin{array}{l}\text { University of Rhode Island } \\
\text { (National Sole Fishery Co- } \\
\text { management Committee, } \\
\text { Department of Fisheries) }\end{array}$ & Rockefeller Foundation & $\begin{array}{c}\text { FIP }+{ }^{1} \text { project } \\
\text { Value chain improvement } \\
\text { Vessel registration }\end{array}$ \\
\hline
\end{tabular}

${ }^{1}$ The FIP+ was a precursor to the accredited Fishery Improvement Project (FIP) work plan. 


\begin{tabular}{|c|c|c|c|}
\hline \multirow{2}{*}{2017} & $\begin{array}{c}\text { University of Rhode Island } \\
\text { (National Sole Fishery Co- } \\
\text { management Committee, } \\
\text { Department of Fisheries) }\end{array}$ & $\begin{array}{c}\text { Resources Legacy } \\
\text { Fund/Sustainable } \\
\text { Fisheries Fund }\end{array}$ & $\begin{array}{c}\text { FIP work plan } \\
\text { http://fisheryprogress.org/fip- } \\
\text { profile/gambia-sole-bottom-set- }\end{array}$ \\
\hline
\end{tabular}

(Source: Fafanding et al., 2010; USAID/BaNafaa, 2014; Gambia sole, March 21, 2018, Fisheryprogress.org, URL: https://fisheryprogress.org/fip-profile/gambia-solebottom-set-gillnet)

A value chain analysis conducted under the USAID funded BaNaafa project revealed constraints for economic growth (Fafanding et al., 2010). The constraints included inadequate cold chains, or temperature-controlled processes in the supply chain (Fafanding et al., 2010). A baseline assessment using Fishery Performance Indicators (FPIs) was conducted in 2012 for Gambian sole (USAID/BaNafaa, 2014; Anderson, Anderson, Chu, Meredith, Asche, Sylvia, Smith, Anggraeni, Arthur \& Guttormsen, 2015). According to wealth enabling indicators identified by Anderson et al. (2015), the Gambian sole fishery scored low for governance, including participation in co-management and management methods. It also underperformed in the post-harvest sector based on metrics used to measure wealth generation. These measures included shrink or loss, product improvement, sanitation and capacity utilization rate (Anderson et al., 2015). Fisheries improvement and development projects have been implemented in these areas since 2010 as shown in Table 2.1 (USAID/BaNafaa, 2014; Fafanding et al., 2010).

A value chain improvement project was implemented in 2015 to test the economic incentive component of the Fishery Improvement Project+ (FIP+). The "FIP+" concept is a market-based model conceptualized under the Rockefeller Foundation's Oceans and Fisheries Initiative. Suitable for small-scale, export-oriented fisheries in developing countries, the FIP+ model incorporates socio-economic 
incentives (symbolized as the + ), including livelihood support, social safety net programs, and simple value chain improvements to the traditional FIP. The purpose of the + components is to boost economic gains to small-scale fishers, which then acts as an incentive for fisheries management. The ice project intervention that is the basis for the study described in this paper aimed to socially and economically benefit fishers and other value chain actors, by using ice and ice coolers to strengthen on-board handling of fish, improve fish quality, and reduce export loss of sole - and in the long run strengthen local support for the FIP process. The potential impact on local fish processors was also investigated in this study. The sole value chain for both the export and local market is illustrated in Figure 2.2.

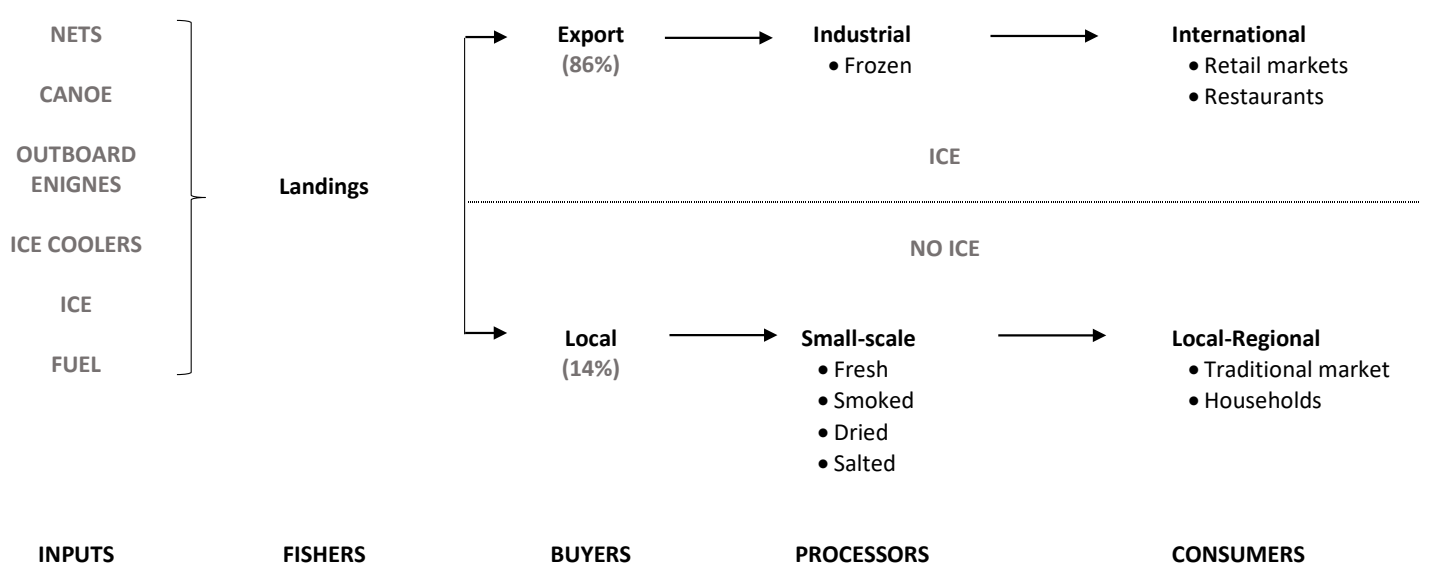

Figure 2.2. Sole value chains.

The study was designed based on recommendations from previous projects and was implemented by the Department of Fisheries (DoFish), the National Sole Fishery Co-Management Committee and the Atlantic Seafood Company (TASC), key stakeholders in the Gambian sole fishery representing state, civil society and market sectors. 


\section{Methodology}

A multi-methods approach combining quantitative and qualitative methods was used to determine post-harvest loss of sole within the supply chain. Data collection was guided using elements from the FAO's PHLA approach (Akande \& Diei-Ouadi, 2010), including the Questionnaire Fish Loss Assessment Method (QLAM), Exploratory Fish Loss Assessment Method (EFLAM) and Load Tracking method (LT). These methodologies are used by Diei-Ouadi \& Mgawe (2011). At the outset of the study, focus groups with fishermen and buyers were held to inquire about post-harvest loss at-sea. The research team also held key informant interviews with ice plant managers and a representative from the only ice box manufacturer in The Gambia to assess the availability and cost of ice and ice boxes. Instruments used during the survey period included new weighing scales, locally made ice boxes, data sheets for enumerators (Appendix A), and prepaid vouchers for purchase of ice provided to fishermen in the treatment group at both study sites. The instruments were pre-tested days prior to beginning the study. Data sheets were regularly collected by the Department of Fisheries Statistics Unit. Post-harvest loss data from each study site were entered weekly and sent to the University of Rhode Island for review during the six-week field-based study. The first author was on-site for half of the study period to monitor research.

Brufut and Gunjur were selected as the study sites based on criteria that included having functioning ice plants adjacent to the sites and the availability of data collectors, fluent in local languages, trained by the Department of Fisheries Statistics Unit. A map of the study sites and special management area is shown in Figure 2.3. 


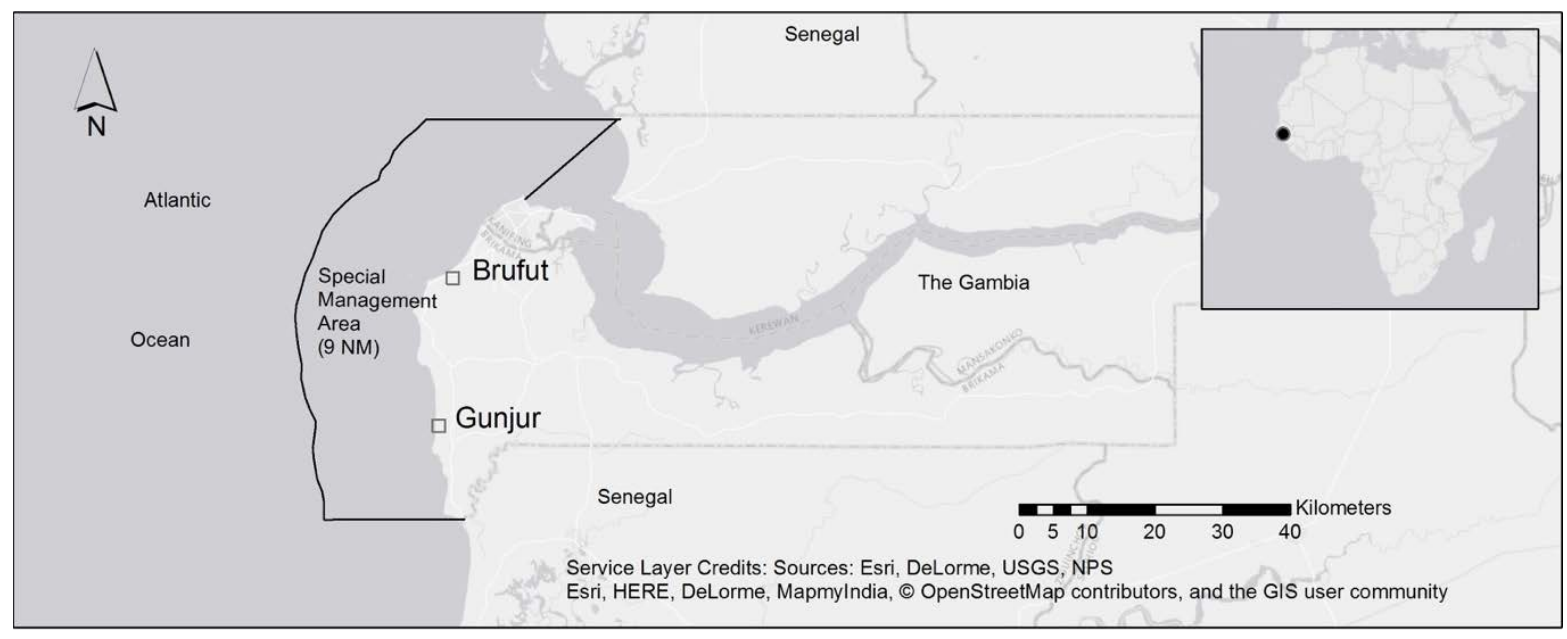

Figure 2.3. Map of study sites and special management area for sole, The Gambia.

This study was quasi-experimental in the sense that participants were not designated at random to the control (fishers not using ice) and treatment (fishers using ice group (Bernard, 2011). A nonprobability sampling technique (purposive) was used to determine the sample size. The sample size was determined by NASCOM and other relevant stakeholders to meet certain criteria and compliance requirements. This technique was preferred because fishers were selected based on the following criteria that included 1) willingness to participate voluntarily over the duration of the study and 2) compliance with a new fishing vessel registration scheme (i.e. the participants had to be registered). The fishermen identified as meeting the criteria were verified by LACOM members and the Department of Fisheries. In total, twenty fishermen were selected, ten at each site. At each site, five fishermen used ice on-board their fishing vessels, whereas the control group of five fishermen fished without ice on-board. Ideally, the sample size would've been larger $(n=30)$, however, due to logistics and financial constraints a larger sample size was not possible. The two groups were similar in terms of vessel size, types of fishing gear, and outboard engines. In total, ten 
buyers participated in the study - five at each site. The buyers, which are men, were selected based on their affiliation with fishermen and the processing plant.

The unit of analysis is post-harvest loss (calculated as proportion lost) to export at the individual fisherman and buyer level. The level of measurement for physical loss is kilograms, an interval variable. The measurement for monetary loss is calculated in Dalasi, the local currency, also considered to be an interval variable. The dependent variable is proportion of sole lost at the individual fisherman boat level and the independent variable is use or non-use of ice. Landings data were collected over 46 consecutive days in August and September, 2015. After the treatment with ice, a survey questionnaire was administered to individual fishermen to determine perceived benefits and challenges posed by the use of ice and ice boxes on-board fishing vessels.

To assess the impact of an export-oriented value chain improvement on local trade and consumption of sole, semi-structured interviews were conducted among a representative quota sample of 40 local fish processors, 20 in Brufut and 20 in Gunjur. These interviews used an interview schedule and picture cards of common types of fish caught and processed in The Gambia, including sole. A representative sampling technique was used based on geographic locations of processing sheds in relation to their socio-economic status. More affluent fish processors were located closest to the beach and less affluent, based on the structure of their sheds, were located furthest from the beach.

Upon landing each day during the study period, data collectors weighed individual fisherman's sole catches on scales. Buyers also weighed sole purchases nearby. The processing plant used their own vehicle to collect sole purchases from 
buyers at each study site daily. Individual weights and prices of good (export grade) and poor-quality (non-export grade) sole were recorded on data sheets at various nodes along the supply chain. Quality scores were classified as good if considered acceptable for export and poor if rejected for export. All recorded weights and prices were entered into an Excel spreadsheet by the statistics unit at the Department of Fisheries. A total of 920 landings were recorded (20 fishermen x 46 days) and collected. Data were analyzed using student's t-test on SYSTAT version 13.1.

\section{Results}

Total weight in kilograms $(\mathrm{kg})$ and proportion loss of sole was captured at nodes along the supply chain and given quality scores at both study sites during the entire study period shown in Table 2.2 and 2.3 respectively. Overall denotes kilograms and proportion of sole sold to the processing plant. Differences in total landings between study sites could be attributed to the number of nets used per vessel, a factor not controlled for in this study.

Table 2.2. Quality scores of sole landings in kilograms (kg).

\begin{tabular}{llrrr} 
& & Good $^{2}$ & Poor $^{3}$ & Total \\
\cline { 3 - 5 } Gunjur & Fisherman & $1,140.3$ & 107.4 & $1,247.7$ \\
& Buyer & $1,135.8$ & 4.5 & $1,140.3$ \\
& Overall & $1,135.8$ & 111.9 & $1,247.7$ \\
\hline \multirow{2}{*}{ Brufut } & Fisherman & $1,579.1$ & 319.1 & $1,898.2$ \\
& Buyer & $1,578.0$ & 1.1 & $1,579.1$ \\
& Overall & $1,578.0$ & 320.2 & $1,898.2$ \\
\hline Overall both sites & & $\mathbf{2 , 7 1 3 . 8}$ & $\mathbf{4 3 2 . 1}$ & $\mathbf{3 , 1 4 5 . 9}$
\end{tabular}

\footnotetext{
2 Export grade.

${ }^{3}$ Non-export grade.
} 
Table 2.3. Quality scores of sole landings by proportion (\%).

\begin{tabular}{llccc} 
& & Good & Poor & Total \\
\cline { 3 - 5 } Gunjur & Fisherman & $91.4 \%$ & $8.6 \%$ & $100 \%$ \\
& Buyer & $99.6 \%$ & $0.4 \%$ & $100 \%$ \\
& Overall & $91.0 \%$ & $9.0 \%$ & $100 \%$ \\
\hline Brufut & Fisherman & $83.2 \%$ & $16.8 \%$ & $100 \%$ \\
& Buyer & $99.9 \%$ & $0.1 \%$ & $100 \%$ \\
& Overall & $83.1 \%$ & $16.9 \%$ & $100 \%$ \\
\hline Overall both sites & & $\mathbf{8 6 . 3 \%}$ & $\mathbf{1 3 . 7 \%}$ & $\mathbf{1 0 0 \%}$
\end{tabular}

Fishermen's proportion loss of sole

Overall, ice on-board vessels fishing made a difference in total proportion loss of sole (Table 2.4). The difference between fishermen using ice and those not using ice on-board vessels is statistically significant for the total sample. Between fishing sites, however, the total proportion of loss differs. In Brufut, ice did not have a statistically significant impact on total proportion loss of sole, whereas in Gunjur the use of ice is statistically significantly correlated with total proportion loss of sole. The distribution and difference of proportion loss of sole clearly indicates variability between sites.

In Table 2.4, mean proportion loss is calculated using total kilograms of sole caught divided by total kilograms of export loss per individual fisherman and by site during the study period. A two-sample t-test (one-tailed) was used to analyze differences in proportion loss of sole. 
Table 2.4. Average fisherman's proportion loss of sole.

\begin{tabular}{|l|c|c|c|c|c|}
\hline \multirow{2}{*}{ Site } & \multicolumn{2}{|c|}{ Mean proportion loss of sole } & \multirow{2}{*}{ P-value } & \multirow{2}{*}{ df } \\
\cline { 2 - 3 } & No ice & Used ice & & & \\
\hline Both sites & 0.22 & 0.08 & 7.25 & $<0.001$ & 566 \\
\hline Brufut & 0.20 & 0.16 & 1.27 & 0.10 & 196 \\
\hline Gunjur & 0.23 & 0.04 & 7.84 & $<0.001$ & 368 \\
\hline
\end{tabular}

The use of ice made a difference in proportion loss of red sole fish during the study period (Table 2.5). The difference between fishermen using ice and those not using ice on-board vessels is statistically significant for the total sample. Between fishing sites, ice did not have a statistically significant impact on proportion loss of red sole in Brufut, whereas in Gunjur, use of ice is statistically significantly related to proportion loss of red sole in Gunjur. Once again this clearly indicates between site variability. We find the same patterns of relationships for black sole (Table 2.5). Impact of the use of ice clearly differs in the two communities and these differences are discussed in the conclusion of the paper.

Table 2.5. Average fisherman’s proportion loss of red and black sole.

\begin{tabular}{|l|c|c|c|c|c|}
\hline \multirow{2}{*}{ Site } & \multicolumn{2}{|c|}{ Mean proportion loss of sole } & \multirow{2}{*}{$\mathrm{t}$} & \multirow{2}{*}{ P-value } & \multirow{2}{*}{ df } \\
\cline { 2 - 3 } & No ice & Used ice & & \\
\hline \multicolumn{7}{|c|}{ Red sole } \\
\hline Both sites & 0.18 & 0.07 & 5.18 & $<0.001$ & 536 \\
\hline Brufut & 0.18 & 0.16 & 0.36 & 0.36 & 179 \\
\hline Gunjur & 0.19 & 0.02 & 7.08 & $<0.001$ & 355 \\
\hline \multicolumn{7}{|c|}{ Black sole } \\
\hline Both sites & 0.35 & 0.19 & 3.98 & $<0.001$ & 358 \\
\hline Brufut & 0.32 & 0.25 & 1.38 & 0.08 & 169 \\
\hline Gunjur & 0.37 & 0.14 & 4.03 & $<0.001$ & 187 \\
\hline
\end{tabular}

Fishermen's revenue from sole

Overall and by site, fishermen using ice on-board vessels earned more from sole landings when excluding the cost of ice (Table 2.6). The differences are 
statistically significant (Table 2.6). This can be partially explained by a lower proportion loss of sole. This study only measures revenue from sole, not other species caught. Average daily revenue from sole is calculated multiplying total kilograms of export-grade red and black sole landed daily by price per kilogram, minus any sole rejected by the buyer (in kilograms). Revenue from sole also includes the price paid to fishermen by local, small-scale processors for non-export grade sole. Table 2.6 represents fishermen's average daily revenue from sole during the study period. A two-sample t-test (one-tailed) was used to analyze differences in fishermen's average daily revenue from sole.

Table 2.6. Average fishermen’s daily revenue from sole excluding price of ice.

\begin{tabular}{|l|c|c|c|c|c|}
\hline \multirow{2}{*}{ Site } & \multicolumn{2}{|c|}{ Revenue from sole } & \multirow{2}{*}{$\mathrm{t}$} & \multirow{2}{*}{ P-value } & \multirow{2}{*}{ df } \\
\cline { 2 - 3 } & No ice & Used ice & & & \\
\hline Both sites & 129.50 & 229.31 & -4.74 & $<0.001$ & 732 \\
\hline Brufut & 219.36 & 292.20 & -1.71 & 0.05 & 331 \\
\hline Gunjur & 56.57 & 175.81 & -10.00 & $<0.001$ & 399 \\
\hline
\end{tabular}

Sole prices vary by site and quality. The ex-vessel, export-grade price of sole in Brufut is 53.2 Dalasi $^{4}$ per kilogram whereas it is 40 Dalasi per kilogram in Gunjur. The difference in ex-vessel price between sites is result of a credit scheme extended to fishermen by buyers in Gunjur. Ex-vessel, export-grade prices are typically based on supply and demand in existing European markets and emerging markets in Asia, primarily driven by China (personal communication, TASC). Multiple factors, not examined in this study determine pricing for non-export grade sole. Difference in pricing is factored into the dependent variable, revenue from sole. The price of ice is excluded in the dependent variable in Table 2.6. Table 2.7 represents fishermen's

${ }^{4}$ Dalasi (GMD) is the Gambian currency (1 USD/39 GMD in September, 2015). 
average daily revenue from sole during the study period as calculated in Table 2.6; however, this analysis includes the price of ice.

Overall and by site, the cost of ice exceeded the difference in revenue earned on average for fishermen using ice (Table 2.7). There is not a statistically significant difference in average revenue earned from sole for fishermen using and not using ice after deducting the cost of ice. Ice plants sell ice to fishermen in Gunjur and Brufut by the basket, a local unit of measure. Each basket carries between 30-40 kilograms of ice. The price of ice varies by site. In Brufut, the price for one basket of ice is 100 Dalasi, and in Gunjur, 130 Dalasi. During the study period, ice was provided daily to the treatment group (fishermen using ice on-board vessels).

Table 2.7. Average fishermen’s daily revenue from sole including price of ice.

\begin{tabular}{|l|c|c|c|c|c|}
\hline \multirow{2}{*}{ Site } & \multicolumn{2}{|c|}{ Revenue from sole } & \multirow{2}{*}{$\mathrm{t}$} & \multirow{2}{*}{ P-value } & df \\
\cline { 2 - 3 } & No ice & Used ice & & & \\
\hline Both sites & 129.50 & 113.09 & 0.77 & 0.78 & 732 \\
\hline Brufut & 219.36 & 192.20 & 0.64 & 0.74 & 331 \\
\hline Gunjur & 56.57 & 45.81 & 0.90 & 0.82 & 399 \\
\hline
\end{tabular}

Buyer's proportion loss of sole

Buyers purchase red and black sole from fishermen at fish landing sites and sell it to the processing plant for export. Overall, the use of ice on-board fishing vessels had a statistically significant ( $p=0.05$, one-tailed test) impact on the buyer's proportion loss of sole (Table 2.8). A buyer's proportion loss was calculated dividing total kilograms of red and black sole rejected at the factory by total kilograms delivered to the factory. In Gunjur, the use of ice on-board fishing vessels had a statistically significant ( $\mathrm{p}=0.03$, one-tailed) impact on the buyer's proportion loss of sole (Table 2.8). In Brufut, ice did not have a statistically significant impact on a 
buyer's export loss. Compared to fishermen's proportion loss of sole, there is less variability overall and between sites among buyer's proportion loss of sole. This could be attributed to better quality post-harvest sole resulting from on-board use of ice.

Table 2.8. Average buyer's proportion loss from sole based on fishermen’s use of ice.

\begin{tabular}{|l|c|c|c|c|c|}
\hline \multirow{2}{*}{ Site } & \multicolumn{2}{|c|}{ Mean proportion loss of sole } & \multirow{2}{*}{ P-value } & \multirow{2}{*}{ df } \\
\cline { 2 - 3 } & No ice & Used ice & & & \\
\hline Both sites & 0.008 & 0.002 & 1.64 & 0.05 & 546 \\
\hline Brufut & 0.001 & 0.002 & -0.40 & 0.65 & 196 \\
\hline Gunjur & 0.012 & 0.002 & 1.84 & 0.03 & 348 \\
\hline
\end{tabular}

Buyer's revenue from sole

Table 2.9 represents buyer's average daily revenue from sole during the study period. This study only measures a buyer's revenue from sole, not other species purchased. A buyer's average daily revenue from sole is calculated multiplying total kilograms of export-quality red and black sole delivered to the factory minus any sole rejected by the factory (in kilograms) multiplied by price per kilogram paid by the factory. The price paid by the factory used for the study was 72.5 Dalasi $/ \mathrm{kg}$, the average of the range for the period (70-75 Dalasi $/ \mathrm{kg})$.

Table 2.9. Average buyer's daily revenue from sole based on fishermen's use of ice.

\begin{tabular}{|l|c|c|c|c|c|}
\hline \multirow{2}{*}{ Site } & \multicolumn{2}{|c|}{ Revenue from sole } & \multirow{2}{*}{ P } & \multirow{2}{*}{ P-value } & df \\
\cline { 2 - 3 } & No ice & Used ice & & & \\
\hline Both sites & 187.49 & 351.71 & -5.61 & $<0.001$ & 732 \\
\hline Brufut & 292.59 & 392.17 & -1.73 & 0.04 & 331 \\
\hline Gunjur & 102.19 & 317.30 & -9.73 & $<0.001$ & 399 \\
\hline
\end{tabular}

Buyers ice sole upon purchase at the fishing site and during delivery to the factory. Unlike fishermen, buyers are provisioned with ice from the factory; therefore, they do not pay for ice. Overall and by site, the difference in a buyer's revenue earned 
from sole obtained from fishermen using ice and those not using ice on-board vessels is statistically significant (Table 2.9).

\section{Gambia fish processors survey}

The Gambia is nutritionally dependent upon fish (Allison, Perry, Badjeck, Neil Adger, Brown, Conway, Halls, Pilling, Reynolds \& Andrew, 2009). It accounts for 59 to 67 percent of total animal protein consumed (Allison et al., 2009). Processing fish is an important economic activity for women, it is estimated 80 percent of fish processors in The Gambia are women (United Nations, 2014). In this survey, all but one respondent was female $(\mathrm{N}=40)$. The mean number of years processing fish was 25 among survey respondents (SD 15.71).

To determine the economic importance of sole to the domestic market, local fish processors were asked to list types of fish purchased on an average yearly basis and rank them from greatest to least. The unit of measure used to rank types of fish purchased was baskets. Accuracy of the unit of measure was not the focus of this survey, rather, types of fish listed were. The first type of fish listed is assigned a score of seven (indicating most important, the highest rank being seven) followed by lower numerical values assigned to other types of fish purchased. Fish not mentioned receive a rank of zero. 
Table 2.10. Difference between ranks of fish at two landing sites for sole in The Gambia.

\begin{tabular}{|c|c|c|c|c|c|}
\hline \multirow{2}{*}{ Type of Fish } & \multicolumn{2}{|c|}{ Mean rank } & \multirow{2}{*}{$\begin{array}{c}\text { Mean } \\
\text { difference }\end{array}$} & \multirow{2}{*}{$\begin{array}{l}\text { Mann-Whitney } \\
\text { U test statistic }\end{array}$} & \multirow{2}{*}{ p-Value } \\
\hline & Brufut $(n=20)$ & Gunjur $(n=20)$ & & & \\
\hline Sardinella & 0.25 & 5.65 & -5.40 & 22.00 & $<0.001$ \\
\hline Catfish & 6.10 & 4.55 & 1.55 & 305.50 & 0.002 \\
\hline Bonga & 0.45 & 5.60 & -5.15 & 28.50 & $<0.001$ \\
\hline Butterfish & 0.25 & 0.60 & -1.20 & 181.00 & 0.324 \\
\hline Stingray & 3.85 & 1.95 & 1.90 & 291.00 & 0.008 \\
\hline Ladyfish & 1.80 & 0.40 & 1.40 & 254.00 & 0.046 \\
\hline Sompat & 0.85 & 0.70 & 0.15 & 216.50 & 0.523 \\
\hline Banda & 1.40 & 0.05 & 1.35 & 253.00 & 0.030 \\
\hline Sole* & 0.00 & 0.00 & 0 & - & - \\
\hline Mix of species* & 0.00 & 0.45 & 0 & - & - \\
\hline Toofish & 1.25 & 0.85 & 0.40 & 215.50 & 0.594 \\
\hline Grouper & 0.60 & 0.10 & 0.50 & 220.50 & 0.287 \\
\hline Anything* & 0.25 & 0.00 & 0 & - & - \\
\hline
\end{tabular}

*Denotes $\mathrm{N}$ is too small for calculating statistic Number in parentheses indicates $N$ associated with the rank at each site

A Mann-Whitney U test was used to determine whether significant differences exist between landing sites in terms of the ranking assigned to the different species. Sole is not listed as a type of fish purchased for domestic consumption using traditional processing methods (Table 2.10). While 90 percent of survey respondents stated that the ranking assigned to different species changes throughout the year, sole remained unlisted. According to respondents, ranks changed throughout the year due to seasonal upwelling and spawning cycles, which impacts the amount and type of fish landed. For example, catfish was the most common type of fish purchased in Brufut, while sardinella and bonga were the most common types of fish purchased in Gunjur. This difference may be attributed to many factors, such as gear types or demand by site. The two most common types of fish preferred for household consumption are catfish and grouper. 


\section{Economic importance of fish processing}

Ninety-five percent of all fish processors surveyed $(n=40)$ stated processing fish is their only source of revenue. Others partially depend on home gardens. Table 2.11 indicates the percentage of revenue derived from fish processing in relation to overall household income. Higher revenues derived from fish processing in Brufut than Gunjur can possibly be attributed to higher landings (Table 2.2) or its proximity to Banjul, a major fish market and the capital of The Gambia. In Brufut, 90 percent of the processors stated that they contribute 50 percent or more to overall household income whereas only 50 percent contribute to the same degree in Gunjur. The difference is statistically significant (Table 2.11).

Table 2.11. Contribution of fish smoking to overall household income by fish processors.

\begin{tabular}{|l|r|r|r|r|}
\hline \multirow{2}{*}{$\begin{array}{c}\text { Contribution to } \\
\text { overall household } \\
\text { income }\end{array}$} & Brufut \% & Gunjur \% & Total & $\begin{array}{c}\text { N, } \\
\text { processors }\end{array}$ \\
\cline { 2 - 5 } & 10.00 & 50.00 & 30.00 & 12.00 \\
\hline $25-50 \%$ & 50.00 & 25.00 & 37.50 & 15.00 \\
\hline $50-75 \%$ & 40.00 & 25.00 & 32.50 & 13.00 \\
\hline $75-100 \%$ & 100.00 & 100.00 & 100.00 & \\
\hline Total & 20.00 & 20.00 & & 40.00 \\
\hline $\mathrm{N}$ & \multicolumn{4}{|c|}{ Chi-square value $=7.69$, DF $=2, p$-Value $=0.02$} \\
Cramer's Vvalue $=0.44$
\end{tabular}

Respondents were asked if sole destined for export impacts the domestic market for sole. In Brufut, fish processors stated they were not impacted by sole exports, whereas in Gunjur, 40 percent stated sole destined for export markets impacts their business because "less catfish is landed (and the price is higher) when more sole 
is caught." The difference is statistically significant between landing sites (Table 2.12).

Table 2.12. Impact of sole exports on local trade.

\begin{tabular}{|l|r|r|r|r|}
\hline \multirow{2}{*}{$\begin{array}{c}\text { Do sole exports } \\
\text { affect your } \\
\text { business? }\end{array}$} & \multicolumn{4}{|c|}{ Landing site } \\
\cline { 2 - 5 } & Brufut & Gunjur & Total & \multicolumn{1}{c|}{$\mathrm{N}$} \\
\hline No & 100.00 & 60.00 & 80.00 & 32.00 \\
\hline Yes & 0.00 & 40.00 & 20.00 & 8.00 \\
\hline Total & 100.00 & 100.00 & 100.00 & \\
\hline N & 20.00 & 20.00 & & 40.00 \\
\hline
\end{tabular}

Chi-square value $=10.00, D F=1, p$-Value 0.002

Yates Corrected Chi-square value $=7.66, D F=1, p$-Value $=0.006$

Fisher Exact Test $p$-Value $=0.003$

$P h i=0.50$

\section{Discussion}

Fish is highly susceptible to post-harvest loss in small scale fisheries in developing countries where the use of ice on-board is limited. Losses are rarely quantified or precisely defined; however, this study defined quality-related losses as export loss, or foregone revenue as a result of failing to meet higher quality standards. Results from this study show that the quality-related losses in the supply chain were approximately 9 to 17 percent (Table 2.3). This range is below or slightly below the post-harvest loss range of 20-75 percent cited by the FAO (2014).

This study contributes to the growing literature on the distribution of profits, or revenue from sales of fish among actors in the value chain in small-scale fisheries. The value chain approach is a tool which can be used to reveal the distribution of economic benefits across a chain. Using the approach showed that icing fish on-board - a simple 
value chain improvement intervention aimed to boost economic gains to small-scale fishermen - provided more economic benefits to buyers than fishermen.

Fisherman's quality loss

Overall, fishermen using ice on-board lost 14 percent less sole on average due to quality than fishermen not using ice. There was variability between sites and species (Table 2.4 and 2.5), however, it was not statistically significant between sites. Interviews with fishermen as key informants provided some explanation for the comparatively higher quality losses of black sole reported during the study period. Fishermen in Brufut stated that they argue with buyers about quality mostly with regard to black sole because it spoils more easily. According to one key informant, black sole loses body fat after spawning-making it more prone to deterioration. Another fisherman explained that black sole has thicker skin and therefore, it takes longer for ice to penetrate the fish. Black sole is reportedly caught furthest from shore; and it may hang and deteriorate in the net longer in warmer sea temperature before reaching the buyers. The average sea temperature at the time of this study was 28 degrees Celsius (https://seatemperature.info). Delays in hauling fish from the net can contribute to post-harvest loss (FAO, 2014), a factor not adequately controlled for and a limitation in this study. Overall and by site, the cost of ice exceeded the difference in revenue earned on average for fishermen using ice for sole (Table 2.7). Based on the prices of fish and ice alone, there is no economic incentive to purchase ice just for sole at the current market price. This study only calculated revenues from sole because it is an important export commodity with a unique value chain. However, fishermen catch other fish species in addition to sole and for a better understanding of the financial 
gains of using ice within the fisher-node of the value chain, future research should look at the impacts of treating the entire catch with ice, not just sole.

\section{Buyer's quality loss}

On average, a buyer purchasing sole for export from a fisherman using ice lost less than one percent during the study period. Compared to fishermen, there is less variability overall and between sites for the buyer's mean proportion quality loss of sole (Table 2.8). The minimal loss incurred by buyers could be explained as a result of better-quality sole entering the value chain, or because they are more discerning buyers. Once purchased, buyers reportedly assume the loss for any sole rejected at the processing plant because there is no significant local market for sole. A buyer's average daily revenue related to buying from boats using ice nearly doubled in this study (Table 2.9). Overall and by site, the difference in a buyer's revenue from sole based on the fishermen's use of ice is statistically significant (Table 2.9). Buyers purchasing sole for export are provisioned with ice from the processing plant in return for the delivering fish. Therefore, they do not incur the additional cost of ice and as a result capture more economic benefit. This finding is consistent with the literature that economic benefits are accrued by buyers, traders and exporters more so than smallscale fishermen.

\section{Impact of exports on the local market}

An important consideration in this study was the impact of increasing the proportion of fish going to exports on local trade and consumption of sole. Results from this study suggest that the intervention did not impact either. Sole was not ranked as economically important species to local and regional markets and it was not 
preferred for household consumption. Hence, there is no perceived loss of supply (Table 2.10). According to respondents in Gunjur, exports of sole impact their local market more than in Brufut (Table 2.12). In Brufut, respondents categorically stated, "sole has a different market and is not our specialty." In Gunjur, respondents felt increased landings of sole (for export) resulted in less catfish which is desired locally. Further studies might explore differences with respect to catfish landings between sites.

The intervention to improve the value chain of sole economically favored buyers more than fishermen but it did not appear to impact the local trade and consumption of sole. For buyers and exporters, there is an economic incentive to purchase iced sole because it results in better quality fish and yields more kilograms for export. For fishermen, however, the economic incentive is eroded given the current cost of ice. In many small-scale fisheries, fishermen target multiple species. Future studies might examine if there are economic incentives to use ice for all species caught. While the cost of ice for fishermen outweighed the economic benefits, the cost of ice coolers was not perceived as prohibitive. The coolers are locally manufactured, used by other fishermen, and bear similarities to those used by fishermen in Senegal. A follow-on study could examine the durability or diffusion of ice coolers among fishermen in The Gambia.

\section{Conclusion}

A dilemma facing developing-country small-scale fisheries engaged in the early stages of the FIP process is attracting more people into the fishery in the absence of controlled access or other exclusionary rights. Overcapacity and overfishing are 
likely if access is not controlled - especially if there is an increase in revenue (e.g. premium prices for higher quality fish) or increased fishing efficiency (e.g. allowing more time at sea as a result of carrying ice on-board). This study recognizes those risks but also acknowledges that the scale of impact seen in this study is small by commercial standards. The management of the Gambian sole fishery is still in transition. It went from little to no fisheries management prior to 2008, toward collective, regulated fisheries management at present.

Fisheries improvement projects (FIPs) are designed to provide long-term biological benefits. However, there is less emphasis placed on the short-term socioeconomic needs of those engaged in the value chain. Implementing the a FIP+ project in The Gambia generated multiple lessons.

First, the study confirmed that ice improves quality and reduces export loss, which is an economic benefit to the fishery. Fishermen reported that iced sole is sought after by buyers who capture more economic benefits than fishermen. A lesson is that if value chain improvements benefit some more than others in the value chain, there may be cost-sharing opportunities such as negotiating a reduced cost of ice for fishermen. This could be done through public or private partners, or a combination of the two, or paying fishermen a premium for icing sole at-sea to offset the cost of ice incurred by fishermen.

Second, fishermen revealed indirect benefits that were not measured quantitatively in the study. Indirect benefits include: efficiencies, buy-in, and behavior change. Fishermen stated that using ice contributed to fuel efficiency, because when carrying ice on-board, fishermen perceived a lower fuel burn rate by not having to 
hurriedly return to shore to sell their catch. The use of ice coolers contributed to vessel cleanliness and hygiene, preventing injuries such as potentially infection producing puncture wounds and cuts caused by broken shells and fish fins on deck. The use of ice coolers made off-loading fish upon landing, quicker. Hence, a lesson is that using ice onboard generated indirect and non-economic benefits that may make it worthwhile even when it does not make direct economic sense to use ice.

Third, understanding the balance of control that exists within a supply chain is important. One fisherman quoted a Gambian proverb to describe a fisherman's financial dependency on buyers, translated as "if I lend you my eye, I will direct you to where you should look.” The underlying meaning is that fishers were dependent on buyers to weigh and purchase their catch, which made them vulnerable to cheating. However, the ice project was designed to increase transparency and collaboration between fishers and buyers. By weighing the catch together, fishers learned that they were entitled to participate in this process. Empowering the fishers to participate in the weighing process was an unanticipated positive result as it leveled the relationships between value chain actors.

The ice project $(+)$ component of the FIP further consolidated supply chain partnership and increased "buy-in” for future research and development projects. It was as a precursor to the accredited FIP work plan, completed in 2017. Both were implemented by key stakeholders in the Gambian sole fishery representing state, civil society and market sectors. The ice project helped strengthen the supply chain and built trust within it, which gave the broader FIP process a boost. It would be interesting to assess how much the ice project strengthened the broader FIP process. 
One idea is to repeat a baseline study conducted in 2012. The study, which used Fishery Performance Indicators developed by the World Bank, found that the Gambian sole fishery underperformed in post-harvest industry performance. Given the improvements made in the value chain, a repeat application might reveal that the FIP+ initiative acted as an incentive to move towards more sustainable management of the sole fishery. 


\section{Appendix A}

Survey instruments

NATIONAL SOLE FISHERY CO-MANAGEMENT COMMITTEE

DATE:

ENUMERATOR:...

ICE $\square \quad$ NO ICE $\square$

FISHERMAN:

SITE:

BOAT

ID:

TIME FISH ON:

\begin{tabular}{|c|c|c|}
\cline { 2 - 3 } \multicolumn{1}{c|}{} & \multicolumn{2}{c|}{ RED SOLE } \\
\cline { 2 - 3 } \multicolumn{1}{c|}{} & $\begin{array}{c}\text { GOOD } \\
\text { QUALITY }\end{array}$ & $\begin{array}{c}\text { POOR } \\
\text { QUALITY }\end{array}$ \\
\hline TOTAL CATCH & & \\
\hline PRICE/KG & & \\
\hline $\begin{array}{c}\text { REJECTS BY BANA- } \\
\text { BANA }\end{array}$ & & \\
\hline
\end{tabular}

\begin{tabular}{|c|c|}
\hline \multicolumn{2}{|c|}{ BLACK SOLE } \\
\hline GOOD & POOR \\
QUALITY & QUALITY \\
\hline & \\
\hline & \\
\hline & \\
\hline & \\
\hline
\end{tabular}

OBSERVATION/REMARKS: 

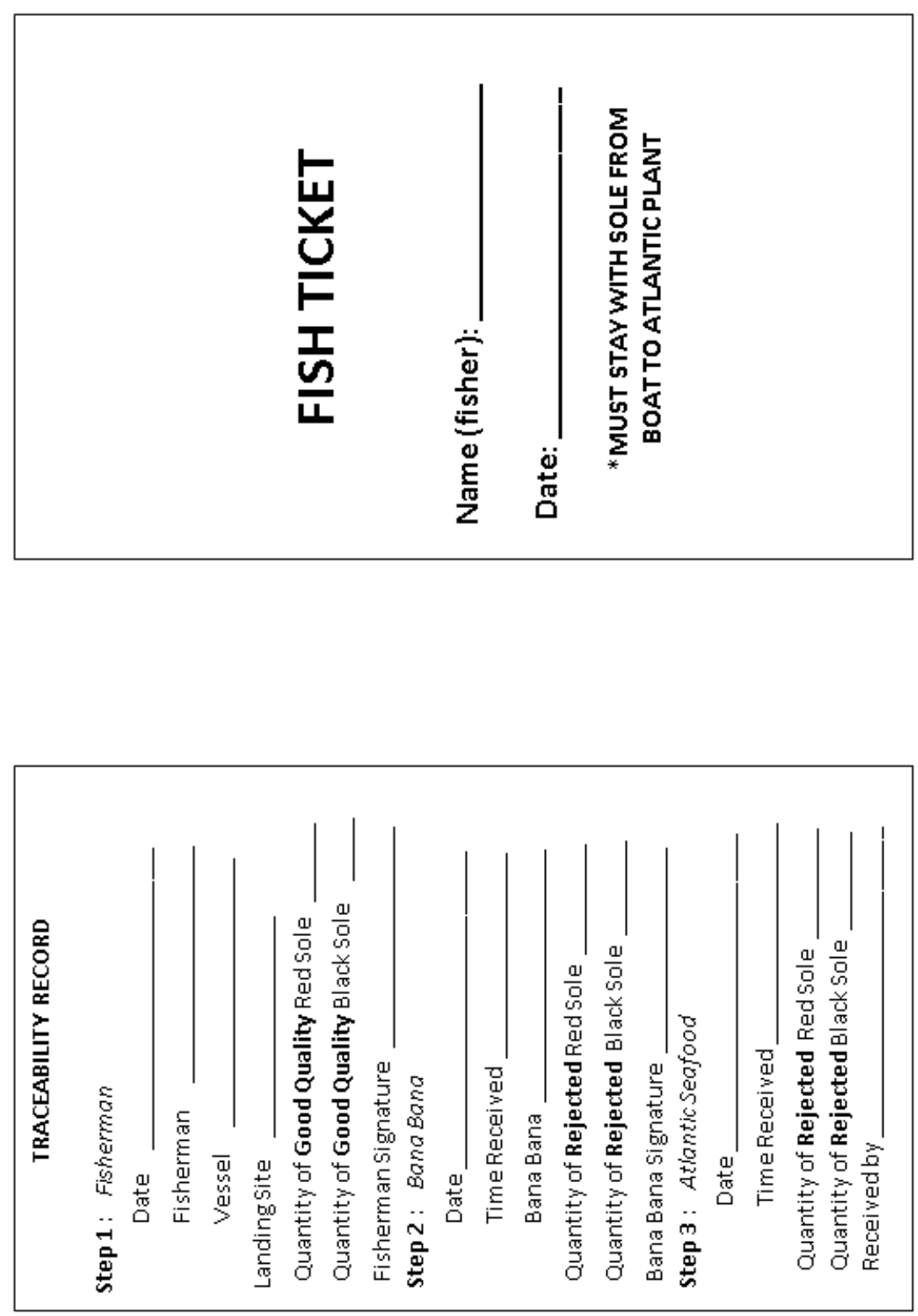


\section{THE UNIVERSITY OF RHODE ISLAND} GRADUATE SCHOOL

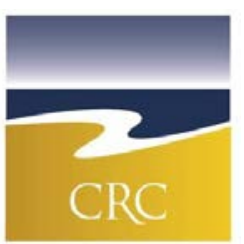

C O A S T A L

RESOURCES

C E N T E R
Narragansett, Rhode Island 02882, USA

Email: Kberan@crc.uri.edu

\section{Fish Processing Survey}

The purpose of this survey is to identify common types of fish processed at fish landing sites in The Gambia. The aim of this survey is to better understand the socio-economic importance of fish processing to households. This survey targets fish processors working at landing sites where fish is delivered after it has been caught atsea.

Instructions: The interviewer will ask questions from the survey sheet and record the respondents answer either by checking off a box $(\square)$ or writing a respondent's answer in the spaces provided. The survey will take approximately 15 minutes to complete.

\section{Demographic information}

Gender

$\square$ Female

$\square$ Male

Landing site

$\square$ Brufut

$\square$ Gunjur

$\square$ Other:

Number of times you have been asked to participate in a survey about your work?

$\square 0$ times $\mid \square 1+$ times

\section{Socio-economic information}

Is fish processing your only source of individual income?

$\square$ Yes $\mid \square$ No

If no, list other sources of income: 
On average, what percent of your individual income from fish processing contributes to your overall household income?

$\square$ Less than $25 \% \quad \square 25-50 \% \quad \square 50-75 \% \quad \square 75-100 \%$

Does your daily income from fish processing vary throughout the year?
$\square$ Never
$\square$ Sometimes
$\square$ Often
$\square$ Always

How many years have you been a fish processor?

years

How far do you live from this landing site?

$\square 0$ to 10 minutes $\quad \square 5$ to 20 minutes $\square 20$ to 40 minutes

How do you get from your house to the landing site to process fish?

$\square$ Walk | $\square$ Taxi $\square$ Bus | $\square$ Other:

Do any of your family members fish at this landing site?

$\square$ Yes $\mid \square$ No

If yes, check all that apply

$\square$ Husband | $\square$ Father $\square$ Brother | $\square$ Son $\square$ Mother | $\square$ Sister $\square$ Cousin | $\square$ Other:

Which of these family members live in your household?

$\square$ Husband | $\square$ Father $\square$ Brother | $\square$ Son $\square$ Mother | $\square$ Sister $\square$ Cousin | $\square$ Other:

How many people live in your household all year-round?

$\square$ 1-3 people $\square$ 3-6 people $\square 6$ or more people

Fish processing information

Do you buy fish from the fishermen at the beach?

$\square$ Yes $\mid \square$ No

What is the biggest challenge for you to get fish to process?

Explain: 
Do you have purchase agreements with specific boats?

$\square$ Yes $\mid \square$ No

List the types of fish you purchase in order of greatest (1.) to least (6.) quantity (kilograms, pieces, baskets). Circle all methods of processing that apply next to each type of fish.

\begin{tabular}{|l|l|}
\hline Fish type & Processing method \\
\hline 1. & Smoke/Dry/Salt/Other: \\
\hline 2. & Smoke/Dry/Salt/Other: \\
\hline 3. & Smoke/Dry/Salt/Other: \\
\hline 4. & Smoke/Dry/Salt/Other: \\
\hline 5. & Smoke/Dry/Salt/Other: \\
\hline 6. & Smoke/Dry/Salt/Other: \\
\hline
\end{tabular}

Does this order change during other times of the year?

$\square$ Yes $\mid \square$ No

List the types of processed fish you sell the most of (in terms of volume, i.e. kilograms, pieces, baskets). List the most types of fish you sell (1.) to the least types of fish you sell (6.). Circle all methods of processing that apply next to each type of fish.

\begin{tabular}{|l|l|}
\hline Fish type & Processing method \\
\hline 1. & Smoke/Dry/Salt/Other: \\
\hline 2. & Smoke/Dry/Salt/Other: \\
\hline 3. & Smoke/Dry/Salt/Other: \\
\hline 4. & Smoke/Dry/Salt/Other: \\
\hline 5. & Smoke/Dry/Salt/Other: \\
\hline 6. & Smoke/Dry/Salt/Other: \\
\hline
\end{tabular}

Does this order change during other times of the year?

$\square$ Yes $\mid \square$ No

Do you bring the fish that you process home to eat?

$\square$ Yes | $\square$ No 
How important is eating fish on a weekly basis for feeding the family?

$\square$ Not important $\square$ Important $\square$ Very important

What type of fish do prefer to eat in your household?

Explain:

Why do you prefer to eat this type of fish in your household?

Explain:

Export information

Does sole (fish) going to the export market in Europe affect your fish processing business?

$\square$ Yes $\mid \square$ No

If yes, please explain how sole going to the export market affects your fish processing business

Thank you for taking the time to respond to this survey. Your time and input is greatly appreciated. 


\section{References}

Akande, G., \& Diei-Ouadi, Y. (2010). Post-harvest Losses in Small-scale Fisheries: Case Studies in Five sub-Saharan African Countries. FAO Fisheries and Aquaculture Technical Paper, (550).

Allison, E. H., Perry, A. L., Badjeck, M., Neil Adger, W., Brown, K., Conway, D., . . . Andrew, N. L. (2009). Vulnerability of National Economies to the Impacts of Climate Change on Fisheries. Fish and Fisheries, 10(2), 173-196.

Anderson, J. L., Anderson, C. M., Chu, J., Meredith, J., Asche, F., Sylvia, G., . . . Guttormsen, A. (2015). The Fishery Performance Indicators: A Management Tool for Triple Bottom Line Outcomes. PloS One, 10(5), https://doi.org/10.1371/journal.pone.0122809.

Belhabib, D., Mendy, A., Zeller, D., \& Pauly, D. (2013). Big Fishing for Small Fishes: Six Decades of Fisheries in The Gambia "The Smiling Coast of Africa."

Béné, C., Lawton, R., \& Allison, E. H. (2010). “Trade Matters in the Fight Against Poverty”: Narratives, Perceptions, and (lack of) Evidence in the Case of Fish Trade in Africa. World Development, 38(7), 933-954. DOI: 10.1016/j.worlddev.2009.12.010.

Bernard, H. R. (2017). Research methods in anthropology: Qualitative and Quantitative Approaches. Rowman \& Littlefield.

Bostock, T., Greenhalgh, P., \& Kleih, U. (2004). Policy Research-Implications of Liberalisation of Fish Trade for Developing Countries: Synthesis report.

Diei-Ouadi, Y., \& Mgawe, Y. I. (2011). Post-harvest Fish Loss Assessment in Smallscale Fisheries. A Guide for the Extension Officer. FAO Fisheries and Aquaculture Technical Paper, (559).

Fafanding, S. Fatajo, James Tobey and Ousman Drammeh. (2010). Sole Fishery Value Chain Assessment. Narragansett, RI: Coastal Resources Center, University of Rhode Island. Retrieved from http://www.crc.uri.edu/download/Final_Sole_VCA_Report_August_20101. pdf.

Fishery Progress. (2018). Gambia Sole-Bottom Set Gillnet. Retrieved from https://fisheryprogress.org/fip-profile/gambia-sole-bottom-set-gillnet.

Food and Agriculture Organization of the United Nations (FAO). (2014). The State of World Fisheries and Aquaculture: Opportunities and challenges. Rome. Retrieved from http://www.fao.org/3/d1eaa9a1-5a71-4e42-86c0-f2111f07de16/i3720e.pdf. 
Gereffi, G., \& Fernandez-Stark, K. (2011). Global Value chain Analysis: A Primer. Center on Globalization, Governance \& Competitiveness (CGGC), Duke University, North Carolina, USA.

Hamilton-Hart, N., \& Stringer, C. (2016). Upgrading and Exploitation in the Fishing Industry: Contributions of Value Chain. Marine Policy, 63, 166171. http://dx.doi.org/10.1016/j.marpol.2015.03.020.

Harland, C. M. (1996). Supply chain management: Relationships, Chains and Networks. British Journal of Management, 7(s1), S63-S80.

Hempel, E. (2010). Value Chain Analysis in the Fisheries Sector in Africa. Note: Study Carried Out in Collaboration with INFOSA and Funded by the Trade Working Group of the PARTNERSHIP FOR AFRICAN FISHERIES, an AU/NEPAD Programme.

Kaplinsky, R. (2000). Globalisation and Unequalisation: What Can Be Learned from Value Chain Analysis? Journal of Development Studies, 37(2), 117-146.

Kaplinsky, R., \& Morris, M. (2001). A Handbook for Value Chain Research. IDRC Ottawa.

Macfadyen, G., Nasr-Alla, A. M., Al-Kenawy, D., Fathi, M., Hebicha, H., Diab, A. M., .. . El-Naggar, G. (2012). Value-Chain Analysis-An Assessment Methodology to Estimate Egyptian Aquaculture Sector Performance. Aquaculture, 362, 18-27.

Morrissey, M. T. (1988). Postharvest Fishery Losses: Proceedings of an International Workshop Held April 12-16, 1987, at the University of Rhode Island, Kingston, RI.

Pomeroy, R. S., \& Andrew, N. (2011). Small-scale Fisheries Management: Frameworks and Approaches for the Developing World. Oxfordshire, UK and Cambridge, MA: Cabi.

Porter, M. E. (1985). Competitive Advantage: Creating and Sustaining Superior Performance. New York: London: Free Press; Collier Macmillan.

Rosales, R. M., Pomeroy, R., Calabio, I. J., Batong, M., Cedo, K., Escara, N., . . . Sarahadil, M. (2017). Value Chain Analysis and Small-scale Fisheries Management. Marine Policy, 83, 11-21.

Sea Temperature. (2017). Water temperature Gambia in August. Retrieved from https://seatemperature.info/august/gambia-water-temperature.html.

The Gambia Department of Fisheries Statistics Unit. (2015). 
United Nations. (2014). The Fisheries Sector in The Gambia: Trade, Value Addition and Social Inclusiveness with a Focus on Women. New York: United Nations.

United States Agency for International Development. (2014). Gambia-Senegal Sustainable Fisheries Project (USAID/BaNafaa) final report. (Final Report No. 624-A-00-09-00033-00). Narragansett, RI: Coastal Resources Center, University of Rhode Island Graduate School of Oceanography. http://pdf.usaid.gov/pdf_docs/PA00K5JG.pdf

Ward, A., \& Jeffries, D. (2000). A Manual for Assessing Post-Harvest Fisheries Losses. Overseas Development Administration. Natural Resources Institute. University of Greenwich. 


\title{
Chapter 3
}

\section{ADOPTION OF IMPROVED SMOKING TECHNOLOGY AMONG FISH PROCESSORS IN GHANA}

\author{
by \\ Kristine Beran $^{1}$, Brian Crawford ${ }^{2}$, Richard B. Pollnac ${ }^{3}$
}

To be submitted to World Development

\footnotetext{
${ }^{1} \mathrm{PhD}$ Candidate, Department of Marine Affairs, University of Rhode Island, RI, 02881, USA, Email: kristine_beran@uri.edu.

2 Adjunct Professor, Department of Marine Affairs and Senior Coastal Resources Manager, Coastal Resources Center, University of Rhode Island Graduate School of Oceanography, Narragansett, RI, USA, Email: bcrawford@uri.edu.

${ }^{3}$ Research Professor, Department of Marine Affairs, University of Rhode Island, RI, 02882, USA, Email: pollnacrb@gmail.com.
} 


\begin{abstract}
We measure factors that influence adoption of improved fish smoking technology in Ghana. The improvement is a fuel-efficient fish smoking stove known as ahotor. The ahotor stove is designed to consume less fuelwood and improve quality of smoked fish products for local and export markets. We measure adoption of the ahotor stove through a field survey. Perceived attributes in diffusion theory (relative advantage, compatibility, complexity, trialability and observability) are tested using principal component analysis. Fifty-one percent of the variance in the data is explained by three components. The components are named technology, product differentiation and labor. We statistically relate adoption of the ahotor stove through perceived attributes and other explanatory variables found in fisheries literature. The best predictors of adoption of the ahotor stove are its technological features except complexity and the ability to pay. Benefits and challenges of implementing improved fish smoking technology in Ghana are discussed. Benefits include energy efficiency, smoke reduction, and hands-on training, while challenges relate to cost and construction of the ahotor stove.
\end{abstract}

Keywords: Diffusion theory, value chain, post-harvest innovations, fish smoking, West Africa, food security, food safety, energy efficiency 


\section{Introduction}

Across sub-Saharan Africa, traditional fish smoking technology continues to evolve primarily as a result of technology transfer and through extension services led by international organizations. Since 1969, the Food and Agriculture Organization (FAO) of the United Nations has played a key role designing and implementing improved fish smoking technology across this region, including Ghana. Recently, attention is placed on improving traditional fish smoking technology relative to food safety, value addition and energy efficiency.

Traditional fish smoking stoves expose processors-most of whom are womento excessive heat and smoke, which raise environmental, economic, occupational and health-related concerns. These concerns are discussed throughout this paper and addressed by diffusing an innovation within this sector.

The FAO (2015) through its Voluntary Guidelines for Securing Sustainable Small-Scale Fisheries in the Context of Food Security and Poverty Eradication, referred to as The Guidelines, recognize the key role the small-scale fisheries postharvest sector plays in the value chain and recommends States should:

- Support the small-scale fisheries post-harvest subsector in producing good quality and safe fish and fishery products, for both export and domestic markets, in a responsible and sustainable manner, Section 7.3

- Address occupational health issues as part of fisheries management, Section 6.12

- Recognize the role of women in the post-harvest sector and support improvements to facilitate women's participation in such work, Section 7.2

- Avoid post-harvest losses and waste and seek ways to create value addition, building not only on existing traditional and local cost-efficient technologies, innovations and culturally appropriate technology transfers, but environmentally sustainable practices with an ecosystem approach should also be promoted, deterring for example, waste of inputs (water, fuelwood, etc.) in small-scale fish handling and processing, Section 7.5 
Fuel-efficient innovations could potentially generate social, economic, and environmental benefits nodes within this sector. Improving energy efficiency through cleaner cooking fuels and technologies is outlined in Goal 7 of the 2030 Agenda for Sustainable Development (United Nations, 2016). However, in order for those benefits to be fully realized, we need to identify factors that facilitate or hinder access or adoption of energy-efficient innovations. We suggest the theory of the diffusion of innovations as a window through which to examine these factors within this context.

Diffusion theory ${ }^{4}$ informs how innovations are implemented and the rate at which they are adopted, or not based on perceived attributes and other explanatory variables such as socio-economic characteristics and communication channels (Rogers, 1995). Diffusion theory has been applied in a variety of disciplines, including agriculture, education, public health and marketing (Rogers, 1995). Diffusion theory has been applied to fishing equipment, such as nets, on-board electronics, and marketing projects for high-end seafood products in industrial fisheries and open ocean aquaculture (Stephenson, 1980; Dewees \& Hawkes, 1988; Tango-Lowry \& Robertson, 2002, Dentoni \& English, 2012).

In Ghana, we investigate factors that influence adoption of an improved fish smoking stove through the lens of diffusion theory. We measure environmental, economic, and health perceptions of the new fish smoking technology among fish processors.

${ }^{4}$ Defined as the process by which an innovation, often technological, is shared or communicated through certain channels over a period of time among members of a community or social system (Rogers, 1995). 


\section{Background}

Fish processing is the main economic activity for women working along Ghana’s 550 km coastline and around lake Volta. Women processors occupy a key node along the supply chain after fishers (Weerantunge, Snyder, \& Sze, 2010; Walker, 2001; Overa, 1993; Madanda, 2003). The most widely used method of processing fish is smoking on stoves. The most common types of smoked fish are small pelagic species. ${ }^{5}$ Small pelagic species account for approximately 70 percent of total marine fish capture in Ghana (FAO, 2016). There are multiple benefits to smoking fish such as enhanced flavor, reduced waste and longer shelf-life that facilitates storage and distribution of fish within and outside of Ghana. Fish that is properly smoked has a shelf-life of five months or more (Gordon, Pulis, \& Owusu-Adjei, 2011).

In Ghana, the rainy season coincides with the peak fishing season for small pelagic species. Post-harvest losses are associated with the rainy season; hence, smoking fish is a necessary means of preserving fish in the absence of refrigeration or sun drying (Akande \& Diei-Ouadi, 2010). The FAO estimates post-harvest loss of smoked fish in weight is between 3 and 17 percent in Ghana (Akande \& Diei-Ouadi, 2010). Losses are attributed to "droppers," or fish falling into the fire, burning, infestation (insects) and breakage (Akande \& Diei-Ouadi, 2010). Improving preservation techniques, such as smoking, could yield more fish for direct human consumption and increase income derived from processing fish. The average per capita consumption of fish in Ghana is estimated at $26 \mathrm{~kg} / \mathrm{yr}$ (FAO, 2016) which is above the world average of $20 \mathrm{~kg}$ per year (FAO, 2016). Fish accounts for 60 percent of animal protein consumed in the Ghanaian diet (FAO, 2016). Between 22 and 26

${ }^{5}$ Sardinella (i.e. sardines), anchovies and mackerel. 
percent of a household's food expenditure is allocated toward purchasing fish (FAO, 2016). Hence, Ghana is particularly dependent on fish as a shelf-stable source of protein.

Essential inputs needed to smoke fish include fish and fuelwood, both renewable natural resources. The nature of these resources in Ghana is open access. The status of these resources in Ghana is declining (Ba, Schmidt, Dème, Lancker, Chaboud, Cury, Thiao, Diouf, \& Brehmer, 2017; Lazar, Asare, Nortey, Kankam, \& Agbogah, 2016). Inefficient fish smoking technology has prompted the development and implementation of improved stove technology. Improved stove technology aims to reduce fuelwood consumption while improving the quality of smoked fish, which in turn benefits nodes further along the chain. The Fisheries Act (625) in Ghana supports standardization of fish quality yet does not provide specifications. In Ghana, the agency responsible for fish quality standards is the Ghana Standards Authority (GSA) in consultation with the Fisheries Commission Post-Harvest Unit and Food and Drugs Authority.

\section{Evolution of Stove Technology in Ghana}

Fish smoking technology is marked by a few notable innovations (Appendix A). Before 1970, stoves used for smoking fish were cylindrical and made of mud or metal (Hall, 2011). The cost of construction was low, yet there were considerable disadvantages, such as inefficient use of inputs (i.e. fuelwood and time) and insufficient capacity to process fish (i.e. no use of trays). Insufficient capacity is a problem in the peak season when most of the fresh fish catch is landed. The introduction of the chorkor stove addressed incapacity. 


\section{Chorkor Stove}

The chorkor stove was developed in Ghana in 1969 by the FAO in collaboration with the Food Research Institute (FRI) and the Council for Scientific and Industrial Research (CSIR) (Kwarteng, Nsiah, \& Aziebor, 2016). The chorkor stove uses trays to smoke fish. Fresh fish is placed on trays and then stacked on top of each other. Chorkor is the most commonly used stove for smoking fish in Ghana.

\section{Morrison Stove}

The morrison stove was developed in 2008 by the Netherlands Development Association (SNV) in collaboration with the private Ghanaian company, Morrison Limited Enterprise. For more information on the morrison stove refer to Odjidja, Yeboah, Abgekpornu, Manu, \& Beran, 2016. This stove was initially promoted by the United States Agency for International Development Ghana Sustainable Fisheries Management Project (USAID/SFMP) given its fuel-efficiency advantage over the chorkor smoker. However, unacceptable levels of polycyclic aromatic hydrocarbons (PAHs) discovered in fish using this stove type resulted in discontinuation of its promotion and prompted a new phase of research and development to better understand PAHs issues in relation to fish smoking technology in general and specifically to design stove components that aim to reduce levels of PAHs and consume less fuelwood (Council for Scientific and Industrial Research [CSIR], Ghana Standards Authority [GSA], \& Kwarteng, 2016). 


\section{Polycyclic Aromatic Hydrocarbons}

Polycyclic aromatic hydrocarbons are carcinogenic and genotoxic substances that pose potential food safety and health hazards concerns (European Food Safety Authority, 2008). According to the FAO/WHO Codex Alimentarius Commission, ${ }^{6}$ formation of PAHs in smoked fish is dependent on various factors some of which include type of wood used to smoke fish, duration of and temperature during smoking, cleanliness and maintenance of equipment and its design, specifically the combustion chamber which influences smoke density inside the chamber (CAC/RCP 68, 2009). Food with direct contact to combustion gases, such as smoking and grilling, ${ }^{7}$ especially over an open flame, contribute to PAHs levels in food products (Akpambang, Purcaro, Lajide, Amoo, Conte, \& Moret, 2009). These processing techniques are common in Nigeria, Ghana and other developing countries (Akpambang et al., 2009). Developed countries have replaced traditional, direct smoking systems with computerized, temperature-controlled systems that are able to reduce formation of PAHs in commercial food production (Horst \& Leinemann, 1996).

The maximum permitted level of benzo[a]pyrene, a key PAH marker, in smoked fish is $2.0 \mu \mathrm{g} / \mathrm{kg}$ (Commission Regulation European Union 1881/2006). A study of commercially smoked fish products in Nigeria reveal high dietary exposure to benzo[a]pyrene (Akpambang et al., 2009). In that study, levels of benzo[a]pyrene exceed the maximum permitted level set by the European Commission in 5 of 6 types

\footnotetext{
${ }^{6}$ The Codex Alimentarius is a collection of standards related to food safety and quality adopted by the Commission formed by the FAO/World Health Organization (WHO) Food Standards Program (FAO/WHO, 2018).

${ }^{7}$ Charcoal grilling usually yields small amounts of PAHs (Akpambang et al., 2009).
} 
of fish sampled, including mackerel at $6.6 \mu \mathrm{g} / \mathrm{kg}$ and mudfish at $38 \mu \mathrm{g} / \mathrm{kg}$ (Akpambang et al., 2009). These fish were smoked using a metal barrel stove (Akpambang et al., 2009). Formation of PAHs, including benzo[a]pyrene in smoked fish in Ghana is discussed in the next section.

\section{Ahotor Stove}

The ahotor stove is the focus of this study. It was developed in 2016 by local and international consultants with guidance from SNV, and public institutions such as the Council for Scientific and Industrial Research (CSIR) and the Fisheries Commission Post-Harvest Unit and the Ghana Standards Authority (GSA), with financial support from the United States Agency for International Development Ghana Sustainable Fisheries Management Project, or USAID/SFMP (Avega \& Tibu, 2017). The ahotor incorporates specific design features shown to reduce PAHs levels for benzo[a]pyrene and PAH4, another indicator of PAHs in food (CSIR et al., 2016). The specific design features that differentiate ahotor from previous stove models is a drip collector and combustion system. A combustion chamber permits faster-flowing, cooler air temperature designed to prevent formation of high PAHs levels on smoked fish. A drip collector that sits on top of the combustion chamber is designed to prevent fat and water released by fish during smoking from dripping into the fire (Kwarteng, Fianko, Amaning, Morrison, Nketia, \& Abbey, 2016).

Chemical analytical tests conducted in Ghana by GSA and in Germany by Eurofins WEJ Contaminants detect lower levels of $\mathrm{BaP}$ and PAH4 in fish smoked by the ahotor than chorkor and morrison stoves (Figure 3.1). 


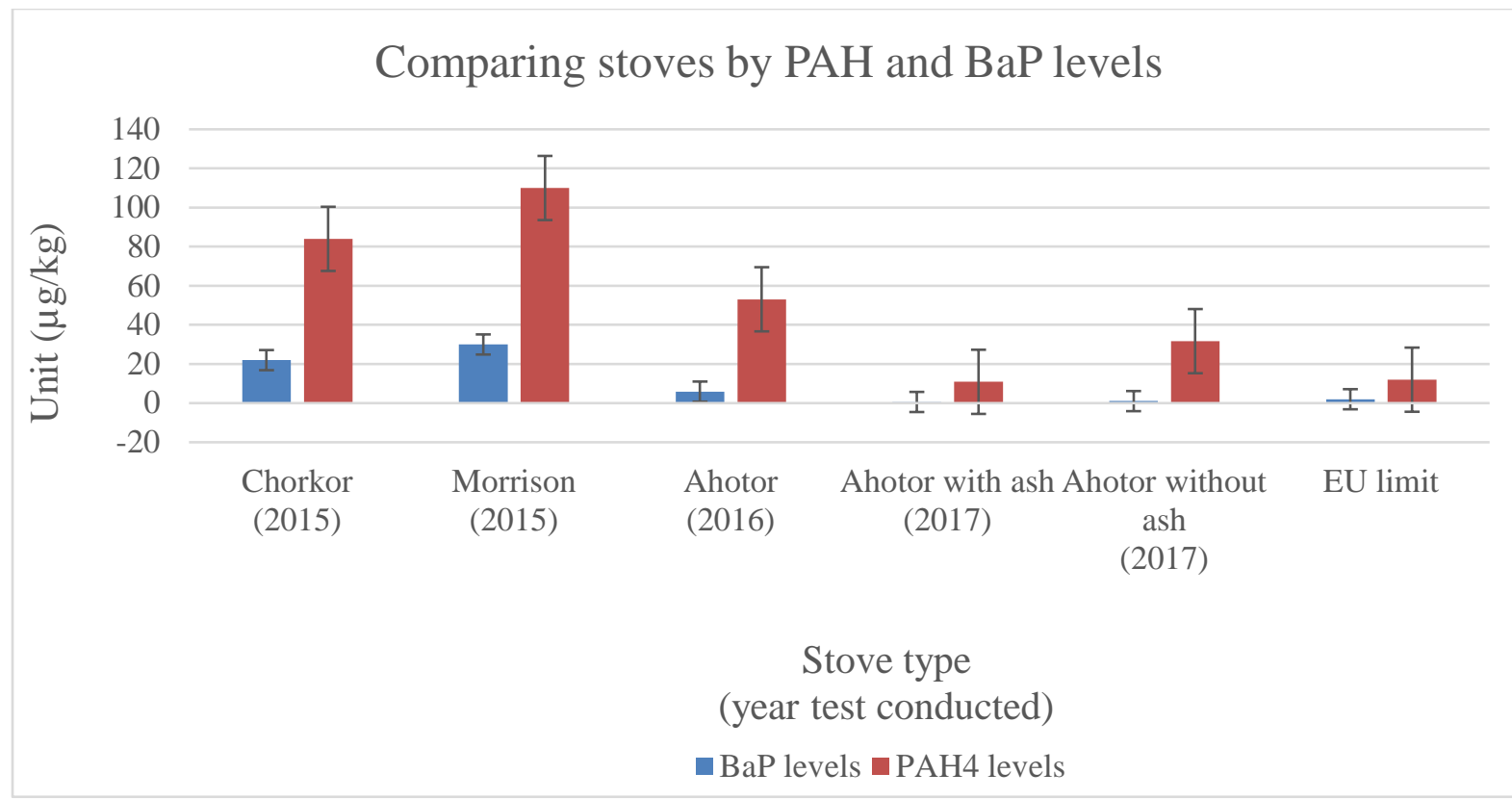

Figure 3.1. PAHs levels by stove types.

Source of data: ${ }^{8}$ Eurofins (2015) and GSA (2017)

Results from analyses shown in Figure 3.1 indicate levels of PAH4 and BaP found in fish smoked by the ahotor stove in 2016 and 2017 are lower than fish smoked by the chorkor and morrison stove in 2015. Results are based a very limited set of samples taken over time. Results from the chorkor and morrison stove are based on one sample, of 1014 and 1005 grams each, respectively. The sample size for the analysis conducted in 2016 for the ahotor stove is 200 grams. Results from the ahotor stove taken in 2017 is based on three samples of smoked fish, each weighing $1 \mathrm{~kg}$. A mean average is calculated if there is more than one sample. Sprinkling ash on top of the drip collector while smoking fish is believed to lower $\mathrm{BaP}$ and PAH4 levels because it absorbs excessive fat and fluid released from fish during the smoking process. Based on a very limited sample, results confirm this hypothesis $(\mathrm{BaP}=0.6$

${ }^{8}$ Data provided by Netherlands Development Association (H. Etsra, personal communication, April 24, 2018). 
$\mu \mathrm{g} / \mathrm{kg}$, PAH4 $=10.9 \mu \mathrm{g} / \mathrm{kg}$ ). Two of three samples of fish smoked by ahotor stove with ash exceed the European Union maximum residue limit $(12 \mu \mathrm{g} / \mathrm{kg})$. At the time of this study only one sample is within the European Union maximum residue limit. Therefore, these data are too limited to draw any conclusions.

\section{Fuel-efficiency}

The ahotor is more fuelwood-efficient than the chorkor stove. Mean difference for fuelwood consumption between the chorkor (306 g/kg) and ahotor (208.6 g/kg) stove is statistically significant ${ }^{9}$ (CSIR et al., 2016). This result is based on comparing consumption of fuelwood between the ahotor and chorkor stoves using a Control Cooking Test ${ }^{10}$ (CSIR et al., 2016). The type of fuelwood used for this test is yaya wood (a local type of hard wood). The same weight of fuelwood was used for three tests conducted according to the Control Cooking Test. See Appendix B for results of the Control Cooking Test.

\section{Definition of Innovation Attributes}

We follow a standardized set of perceived attributes of innovations according to diffusion theory to determine factors that influence adoption of the ahotor stove in Ghana. Perceived attributes are relative advantage, compatibility, complexity, trialability, and observability (Rogers, 1995). According to diffusion theory, 49-87 percent of variance in rate of adoption is explained by these five attributes (Rogers,

${ }_{9}^{9}$ T-test $=9.513, \mathrm{df}=2$.

${ }^{10}$ An experimental method that compares stove performance following a standardized cooking scheme (Rob Bailis, 2004). In this study, equal weights of fuelwood and fish are used to compare the stoves' performance with respect to fuel-efficiency under similar conditions and procedures. 
1995). The rate of adoption is measured by the number of individuals that adopt an innovation within a specific period, such as a year (Rogers, 1995).

Relative advantage is often associated with economic profitability, low initial cost, savings of time and effort and social prestige (Rogers, 1995). However, more non-economic factors are needed to understand different motivations for adopting an innovation (Rogers, 1995). In this study, we explore non-economic attributes of relative advantage such as less smoke nuisance (to the eyes), a personal health benefit.

Compatibility is the degree to which the innovation, or idea is consistent with the one it supersedes (Rogers, 1995). Innovations can fail if they counter strongly held cultural beliefs and values (Rogers, 1995). For example, a variety of rice promising higher yields was introduced in South India but it was not adopted because it failed to account for consumer taste. In this study, we measure compatibility with questions related to labor and workload given the different stove designs.

Complexity is measured by the degree to which an innovation is perceived as difficult to understand or use (Rogers, 1995). It is the only attribute negatively correlated with adoption (Rogers, 1995). This study measures complexity based on the stove's construction and maintenance. Trialability is defined as the relative ease of trying-out new ideas or innovations which reduces uncertainty (Rogers, 1995). In this study, we measure trialability by asking respondents if they were trained to use the stove before adopting it.

Observability is characterized by an innovation’s results (Rogers, 1995). Some innovations are more visible than others, especially physical or material objects, such as cellular phones, which is positively correlated with adoption. Innovations that are 
hard to describe or are not visible are negatively correlated with adoption (Rogers, 1995). In this study, we measure observability based on a stove's visibility (to others) and quality (of fish) it produces.

\section{Communication Channels}

The means through which an idea or innovation is communicated from one individual to another influencing adoption (Rogers, 1995). For example, mass media channels convey information rapidly and efficiently, while interpersonal channels (i.e. face-to-face) do not, yet, they may be more persuasive (Rogers, 1995). In this study, channels used to convey information about the ahotor stove include newspapers, radio and television, peer-to-peer contact and change agents. Change agents work with the USAID/SFMP, the lead donor agency behind the development of the ahotor stove.

\section{Methodology}

A field study was conducted in five regions across Ghana from June, 2017 to May, 2018 to better understand perceptions and attributes that may impact adoption of the ahotor and chorkor stove.

\section{Research Design and Survey Instruments}

A mixed-methods, qualitative and quantitative approach was used to collect primary and secondary data (Robson, 2011). Key informants $(n=10)$ provided information related to construction of both stoves, and communication channels and financing mechanisms specific to the promotion of the ahotor stove under the USAID/SFMP (Appendix C). Reliability of key informants was tested through the agreement technique, or when two informants from the same organization provide the

same response (Poggie, 1972). Direct and participant observation determined 
concordance between actual versus intended use of improved fish processing technology. A GoPro video camera was used to record processors load wood, arrange fish on trays, stack and alternate trays while smoking fish on different stove types. Video recordings were later used by the researcher to complete field notes. A structured survey was administered to fish processors $(\mathrm{N}=112)$ to test the research questions (Appendix D). A sampling frame was built comparing two stoves, or treatments among the processor population in Ghana. They are 1) ahotor treatment group, and 2) chorkor treatment group.

\section{Study Sites}

Study sites for the ahotor treatment group is based on their location in five regions across Ghana. The chorkor group sample was also drawn from five regions across Ghana. All study sites are marked using a global positioning device. See Figure 3.2 and 3.3 for locations of sample sites.

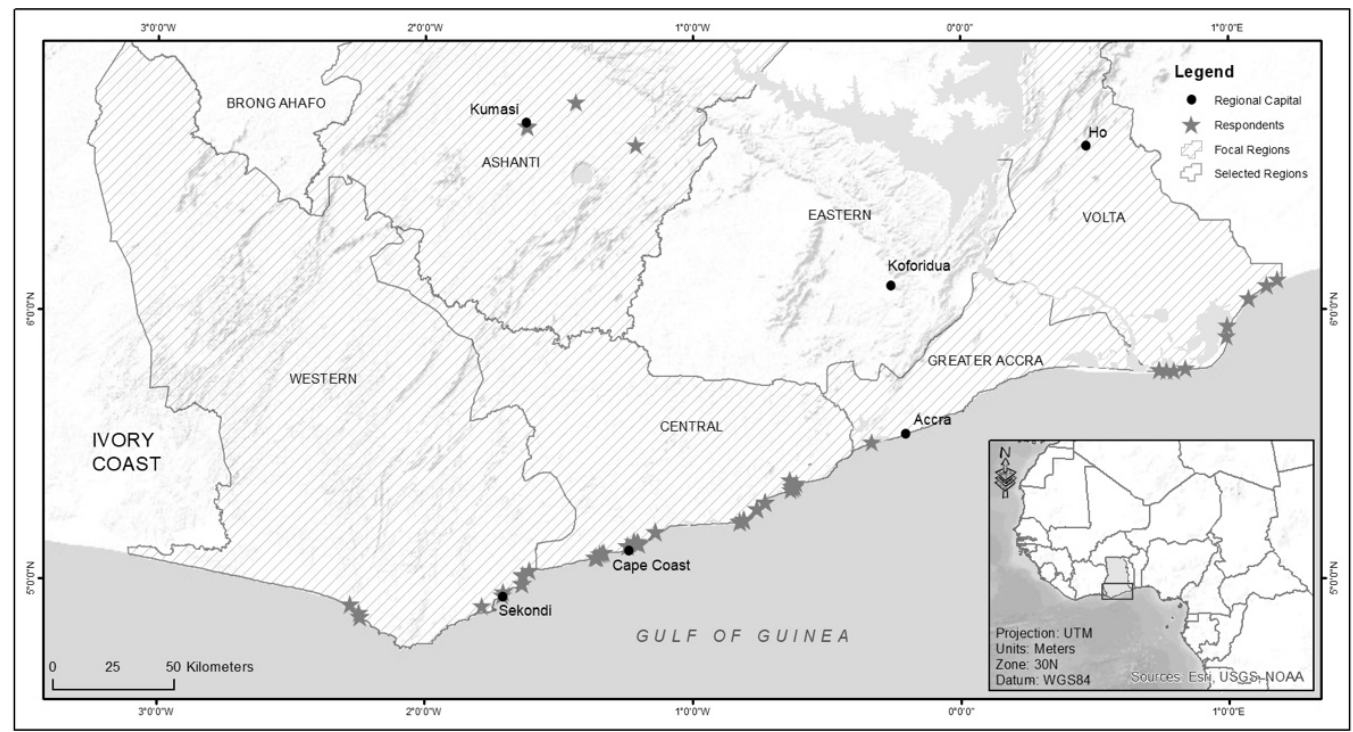

Figure 3.2. Location of Ghana and study sites. 


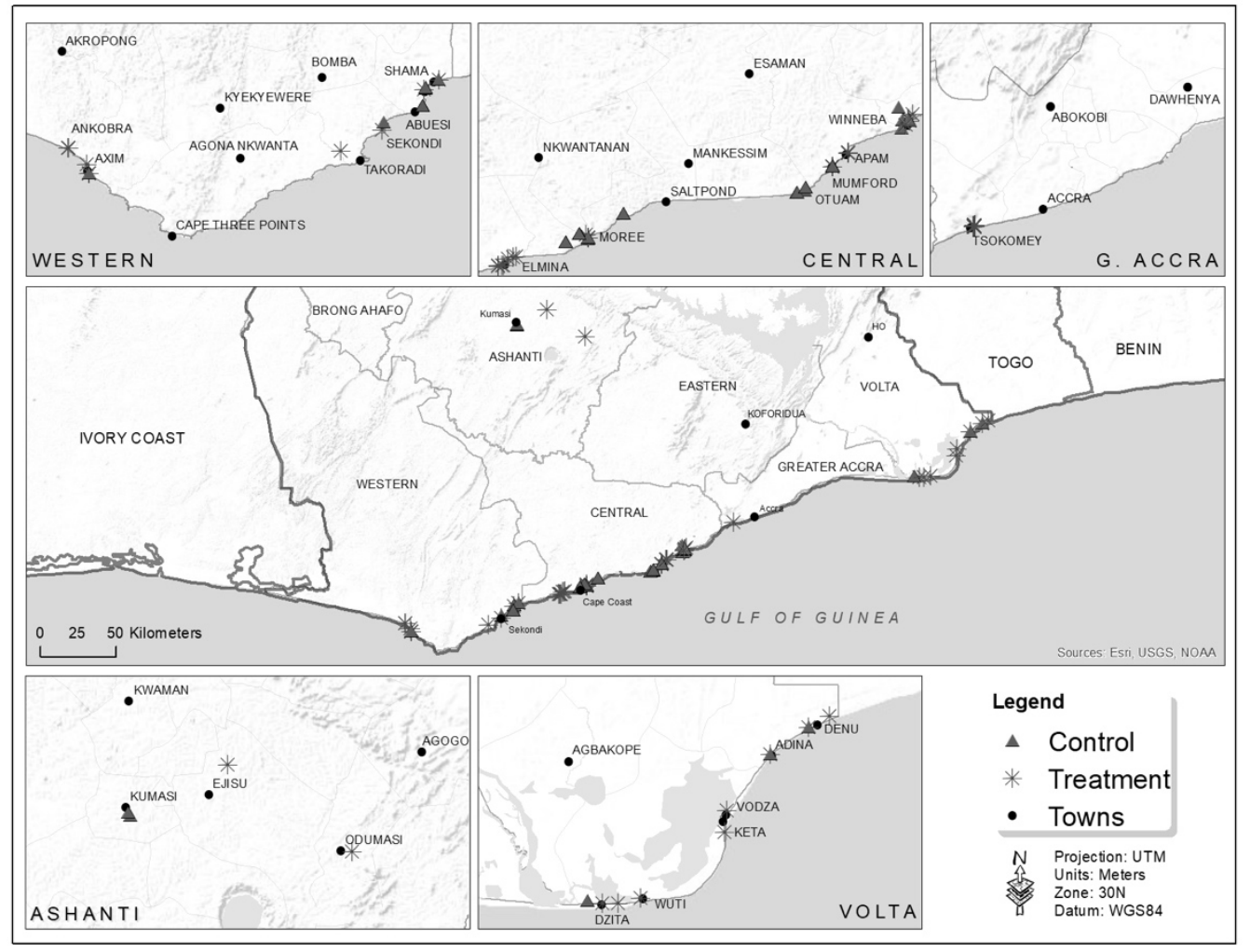

Figure 3.3. Location of sample sites by region in Ghana.

Location of sample sites by region in Ghana. In the legend, control means those currently using the chorkor stove while treatment means those that own and use an ahotor stove regardless how it was acquired. ${ }^{11}$

\section{Ahotor Treatment Group}

The sample frame is built based on a census using a list of names of fish processors who own the ahotor stove $(n=49)$. The list was provided by the SFMP. Means of ownership, however, differ. In 2016, the SFMP fully subsidized the ahotor stove to select beneficiaries. Thereafter, it has been available for direct purchase. Most of those who own the ahotor stove previously-or in addition to-use the chorkor stove. Types of owners of the ahotor stove is subsequently discussed.

\footnotetext{
${ }^{11}$ Respondents within the treatment group may also own a chorkor stove in addition to the ahotor stove.
} 
Demonstration user is a term used for fish processors who received the ahotor stove based on certain criteria established by project partners under this project. Criteria for selection of demonstration users is determined by project partners under the SFMP (USAID/SFMP, personal communication, June-August, 2017). Vulnerable household is another term used under this project for a person, or household susceptible to child labor and trafficking. This project provisioned a subset of vulnerable households with the ahotor stove to generate income, because there is reason to believe that economic hardship contributes to child labor and trafficking (Avega \& Tibu, 2017).

The self-finance group are individuals who have purchased the ahotor stove at current market price. Fish processors who have made a deposit, or payment toward a purchase of the ahotor stove-at the time of this study-form a group called deposits. Location (i.e. region in Ghana) and means of ownership of the ahotor stove is summarized in Table 3.1. The terms used to describe owners in Table 3.1 implies that those that own the ahotor stove are potential adopters of it. Rogers (1995, p. 21) defines adoption as "a decision to make full use of an innovation as the best course of action available.”

Table 3.1. Owners of ahotor stove by region (as of August, 2017).

\begin{tabular}{|c|c|c|c|c|}
\hline \multirow[b]{2}{*}{ Region } & \multicolumn{4}{|c|}{ Ahotor owners } \\
\hline & Demonstration & $\begin{array}{l}\text { Vulnerable } \\
\text { household }\end{array}$ & $\begin{array}{c}\text { Self- } \\
\text { finance }\end{array}$ & Deposits \\
\hline Western & 10 & 0 & 1 & 0 \\
\hline Central & 11 & 16 & 0 & 0 \\
\hline Volta & 6 & 0 & 0 & 2 \\
\hline Greater Accra & 1 & 0 & 0 & 0 \\
\hline Ashanti & 0 & 0 & 2 & 0 \\
\hline Total & 28 & 16 & 3 & 2 \\
\hline
\end{tabular}


Criteria used to select beneficiaries of the ahotor stove was established by region under the SFMP. Refer to Table 3.2 for selection criteria. Criteria varies by region (Table 3.2). There are no standardized criteria for demonstration users, however, there is for vulnerable households as described in Beran and Crawford (2018).

Table 3.2. Selection criteria for ahotor stove beneficiaries by region.

\begin{tabular}{|c|c|}
\hline Region & Selection criteria \\
\hline Volta & $\begin{array}{l}\text { - } \text { Accessible (willing to demonstrate) } \\
\text { - } \quad \text { Position of authority }\end{array}$ \\
\hline Central & $\begin{array}{l}\text { - } \\
\text { - } \text { Accessible (based on location) } \\
\text { - } \quad \text { Active participant during trainings (of stove) } \\
\text { - } \quad \text { Past experience with morrison stove }\end{array}$ \\
\hline Western & $\begin{array}{l}\text { - } \text { Active participant during trainings (of stove) } \\
\text { - } \quad \text { Cleanliness of processing area } \\
\text { - } \quad \text { Position of authority }\end{array}$ \\
\hline Greater Accra & - $\quad$ Accessible (based on location) \\
\hline Ashanti & $\begin{array}{l}\text { - N/A because respondents in this region were self- } \\
\text { selected, and not selected by the USAID/SFMP } \\
\text { project }\end{array}$ \\
\hline
\end{tabular}

Not all owners of the ahotor stove have fully adopted it. Therefore, a new category within the treatment group is formed and referred to as non-adopter. A nonadopter is someone who owns the ahotor stove but has used it one time or not at all. Reasons for non-adoption include lack of land to place the stove, lack of raw material or access to preferential markets (e.g. export or high-end supermarkets in Ghana), lack of working capital and missing stove components, such as a grate and drip collector. Refer to Table 3.3. Table 3.3 also accounts for individuals who were selected to demonstrate use of the stove to other fish processors but have not done so given reasons provided. 
Table 3.3. Reasons for non-adoption of the ahotor stove $(\mathrm{N}=9)$.

\begin{tabular}{|l|l|l|l|}
\hline $\begin{array}{c}\text { Interview } \\
\text { number }\end{array}$ & Region & Type of respondent & \multicolumn{1}{|c|}{ Reason } \\
\hline 19 & Central & Vulnerable household & $\begin{array}{l}\text { Does not own land. Ahotor } \\
\text { was built on someone else's } \\
\text { land far away from where the } \\
\text { person lives }\end{array}$ \\
\hline 26 & Central & Vulnerable household & Missing component (grate) ${ }^{13}$ \\
\hline 27 & Central & Vulnerable household & $\begin{array}{l}\text { Missing component (drip } \\
\text { collector) }\end{array}$ \\
\hline 34 & Central & Demonstration user & $\begin{array}{l}\text { Lack of raw material (fish } \\
\text { from cold storage) }\end{array}$ \\
\hline 38 & Central & Vulnerable household & $\begin{array}{l}\text { Lacks working capital to buy } \\
\text { fish to process }\end{array}$ \\
\hline 44 & Central & Vulnerable household & $\begin{array}{l}\text { Lacks working capital to buy } \\
\text { fish to process }\end{array}$ \\
\hline 49 & Western & Demonstration user & $\begin{array}{l}\text { Lack of preferential market } \\
\text { (export) }\end{array}$ \\
\hline 50 & Western & Demonstration user & $\begin{array}{l}\text { Lack of raw material and } \\
\text { high-end markets (quality fish } \\
\text { such as redfish, cassava to sell } \\
\text { to supermarkets in Ghana) }\end{array}$ \\
\hline 74 & Central & Vulnerable household & $\begin{array}{l}\text { Lacks working capital to buy } \\
\text { fish to process }\end{array}$ \\
\hline
\end{tabular}

\section{Chorkor Treatment Group}

The chorkor stove treatment group consists of sixty-three fish processors. Previously, this group used traditional round, mud stoves or later, metal barrel stoves. The chorkor treatment group is drawn using a convenience sample, a non-probability sampling technique. This technique was chosen due to time constraints. Selection of participants was based on availability and willingness to participate in the study. This study coincided with the peak season when processors are buying, processing (e.g. smoking) and trading fish. To minimize sampling bias, half of the sample is drawn

\footnotetext{
${ }^{12}$ Re-location pending (February, 2018).

${ }^{13}$ Grate replaced (February, 2018).

${ }^{14}$ Drip collector replaced (February, 2018).
} 
from non-SFMP project sites in Ghana. In theory, these sites are not targeted for promotion of ahotor stove.

All structured interviews were conducted using primarily one, and as needed two local translators between English and the local dialect spoken. Prior to administering the survey, the phrasing of the survey instrument was reviewed by native speakers and changes are made to the wording of questions as needed to ensure

local understanding. For data quality assurance, survey instruments were pre-tested four times, twice with fish processors and twice with translators.

A cloud-based paperless survey instrument was used for the structured questionnaire administered to 112 fish processors using a tablet to enter responses and sent via Wi-Fi to a cloud-based server for storage at the conclusion of the interview. Data are downloaded into an Excel workbook. One respondent is removed from the data set due to mis-entry of data. Hence, the sample size in this study is 111 .

\section{Measurement of Variables and Results}

Measurement of variables to determine adoption of ahotor and chorkor stoves is discussed in this section. Results of quantitative and qualitative data are presented.

\section{Communication Channels}

Information about the ahotor stove is conveyed through trainings (e.g. workshops and demonstrations), radio, television and newspapers. Thirty-one percent first heard about the stove through SFMP-led trainings, 6 percent through media 
outlets $^{15}$ and 63 percent from other sources such as peer-to-peer contact with relatives or other processors.

\section{Socio-economic Variables}

Personal and socio-economic variables are chosen based on prior innovation studies related to fisheries (Dewees \& Hawkes, 1988; Tango-Lowy \& Robertson, 2002). Descriptions and measurements of these variables are shown in Table 3.4.

Table 3.4. Description of socio-economic variables.

\begin{tabular}{|c|c|c|}
\hline Variable & Measurement & Description \\
\hline Age & Ratio (years) & Respondent's age \\
\hline $\begin{array}{c}\text { Years of } \\
\text { experience }\end{array}$ & Ratio (years) & Years of experience smoking fish \\
\hline Cosmopolitanism & $\begin{array}{c}\text { Ratio } \\
\text { (markets) }\end{array}$ & Number of markets fish is sold \\
\hline Income & Ordinal & Percentage of income from smoking \\
\hline $\begin{array}{c}\text { Material style of } \\
\text { life }\end{array}$ & Scale & $\begin{array}{c}\text { Scale calculated based on presence/absence } \\
\text { of household structure, contents, and access } \\
\text { to electricity water and sanitary facilities }\end{array}$ \\
\hline
\end{tabular}

Age, years of experience and number of markets where fish was sold is measured within the ahotor treatment group (e.g. types of owners) and between treatment groups, or those an ahotor or chorkor stove (Table 3.5).

\footnotetext{
${ }^{15}$ Media outlets used by the SFMP to promote the ahotor stove includes newspapers, television and radio (USAID/SFMP, personal communication, June-August, 2017).
} 
Table 3.5. Difference between and within groups of socio-economic variables.

\begin{tabular}{|c|c|c|c|c|c|c|c|c|c|}
\hline \multirow{2}{*}{ Variable } & \multicolumn{5}{|c|}{ Ahotor group } & \multicolumn{4}{|c|}{ Chorkor vs. Ahotor groups } \\
\hline & MeantD & MeanvH & MeanNA $_{\mathrm{NA}}$ & F-ratio & p-Value & Mean $_{\mathrm{A}}$ & Meanc & F-ratio & p-Value \\
\hline Age & 48.1 & 45.4 & 45.6 & 0.34 & 0.71 & 47.1 & 49.3 & 0.99 & 0.32 \\
\hline Years smoking & 25.3 & 25.2 & 23.6 & 0.06 & 0.95 & 24.9 & 31.3 & 2.33 & 0.02 \\
\hline (\#) Markets & 2.7 & 2.4 & 2.3 & 0.22 & 0.80 & 2.6 & 2.5 & -0.10 & 0.92 \\
\hline $\mathbf{N}$ & 29 & 10 & 9 & - & - & 48 & 63 & - & - \\
\hline
\end{tabular}

$\mathrm{TD}=$ Ahotor demonstration users, $\mathrm{vH}=$ Ahotor vulnerable household users, $\mathrm{NA}=$ Ahotor Non-adopters, $\mathrm{A}=$ Ahotor group, $\mathrm{c}=$ Chorkor group

Analysis of variance (ANOVA) is used to analyze differences between group means for the ahotor treatment group (Table 3.5). ${ }^{16} \mathrm{~A}$ two-sample t-test compares difference of means between groups (i.e. ahotor and chorkor) among these variables in Table 3.5. The ahotor group has less experience smoking fish than the chorkor group (Table 3.5). The difference is statistically significant ( $\mathrm{p}-\mathrm{Value}=0.02, d f=109$ ).

Illiteracy is high in coastal fishing communities in Ghana. A study conducted by Crawford, Gonzales, Nyari-Hardi, \& Sarpong (2016) reveals 77 percent of respondents are illiterate. Older persons and females are more likely to be illiterate (Crawford et al., 2016). To gage financial literacy, this study asks respondents how they record their earnings from processing fish. The question is open-ended; however, respondents ether state they keep record of it "in their head” or "written.” Within the chorkor group ( $\mathrm{n}=63), 56$ percent state that they keep record of in it in their head and 44 percent keep written records. Within the ahotor group $(n=48), 58$ percent keep record of expenses in their head while 42 percent keep written records. The difference is not statistically significant (Chi-square $=0.09, d f=1$, $\mathrm{p}$-Value $=0.77$ ).

\footnotetext{
${ }^{16} \mathrm{Mean}_{\mathrm{A}}$ is defined as respondents using the ahotor stove whereas Mean $\mathrm{C}$ is defined as respondents using the chorkor stove.
} 
Respondents are asked to state their dependence on fish processing for income generation. The level of measurement is ordinal (categories: 0-25 percent, 25-50 percent, 50-75 percent and 75-100 percent). Data are transformed into two groups, 075 and 75-100 percent due to low cell frequency counts in resultant tables $(<5)$. Within the 75-100 percent range, the chorkor group claim higher dependence on fish processing as a source of household income (87.3 percent), whereas the ahotor group is slightly less (73.9 percent). The differences are not statistically significant (Chisquare $=3.18, d f=1, p$-Value $=0.07$, Fisher Exact Test two-tailed $p=0.09, n=109)$. Income is difficult to measure in fishing households as daily income varies widely, seasonally and annually based on variations in fish catch. Therefore, a material style of life (MSL) scale is used as a wealth indicator, or substitute for income. Previous studies use MSL to determine social status within the community based on possession of household assets and structure (Pollnac \& Crawford, 2000; Cinner, Daw, \& McClanahan, 2009).

In this study, the MSL scale is determined by the presence or absence of select household contents such as a radio or refrigerator, type of house structure, such as roof and floor and access to services such as electricity and water, or indoor plumbing. A total of 17 indicators are scored in dichotomous form, or 1 for presence and 0 for absence of this item or access to it. The indicators are shown in Table 3.6. 
Table 3.6. Material style of life indicators.

$\begin{array}{ll}\text { Sewing machine } & 0,1 \\ \text { Tape player } & 0,1 \\ \text { Radio } & 0,1 \\ \text { Refrigerator } & 0,1 \\ \text { Television } & 0,1 \\ \text { Roof (metal) } & 0,1 \\ \text { Roof (slate) } & 0.1 \\ \text { Roof (other or thatched) } & 0,1 \\ \text { Floor (dirt) } & 0,1 \\ \text { Floor (cement) } & 0,1 \\ \text { Floor (others, or mixture, or tile) } & 0,1 \\ \text { Indoor plumbing } & 0,1 \\ \text { Electricity } & 0,1 \\ \text { Toilet (public) } & 0,1 \\ \text { Toilet (private) } & 0,1 \\ \text { No toilet } & 0,1 \\ \text { Kumasi Ventilated Improved Pit (KVIP) } & 0,1\end{array}$

Principal component with varimax rotation is used to reduce these indicators into scales that reflect patterns of interrelationships among the indicators (Pollnac \& Poggie, 2006). Principal component analysis reduces multiple variables down to a smaller number of components. The scree test (Cattell, 1966) is used to select the number of components. Three components are selected, in total they account for 47 percent of the variance in MSL items (Table 3.7).

Items ${ }^{18}$ loading highest $(>.40)$ on each component helps to identify what each component represents and defines the underlying dimension that binds them together. In other words, items with high positive loadings contribute more strongly to a positive component score than those with low or negative loadings (Pollnac \& Poggie, 2006).

171 =presence of or access to, $0=$ absence.

${ }^{18}$ One of items (a type of toilet called KVIP) is removed from the data set because of a low component loading (<.40). 
The first component is defined primarily by positive loadings on household electrical appliances and a metal roof. A metal roof is less expensive than "slate". Slate is a mixture of cement, sand and water. It is typically used as building material in coastal communities because it does not rust. The first component is named household goods. The second component reflects the construction of a house consisting of positive loadings for a slate roof and cement floor. The second component is named house construction. The third component is defined by positive loadings on access to services such as indoor plumbing for a private toilet and electricity to run a refrigerator. These items are considered a luxury to purchase and maintain. Therefore, the third component is named luxury items.

Table 3.7. Principal component analysis of material style of life $(n=111)$.

\begin{tabular}{|c|c|c|c|}
\hline & Household goods & $\begin{array}{c}\text { House } \\
\text { construction }\end{array}$ & Luxury items \\
\hline & $\begin{array}{c}\text { Variables and } \\
\text { Loadings } \\
\end{array}$ & $\begin{array}{c}\text { Variables and } \\
\text { Loadings } \\
\end{array}$ & $\begin{array}{c}\text { Variable and } \\
\text { Loadings }\end{array}$ \\
\hline Sewing machine & 0.56 & -0.04 & 0.06 \\
\hline Tape player & 0.63 & 0.08 & 0.02 \\
\hline Radio & 0.63 & 0.13 & 0.04 \\
\hline Refrigerator & 0.46 & 0.09 & 0.50 \\
\hline Television & 0.67 & 0.24 & 0.20 \\
\hline Roof (metal) & 0.70 & -0.03 & -0.04 \\
\hline Roof (slate) & -0.67 & 0.53 & -0.02 \\
\hline Roof (other) & 0.17 & -0.67 & 0.07 \\
\hline Floor (dirt) & -0.11 & -0.58 & -0.01 \\
\hline Floor (cement) & 0.14 & 0.73 & 0.21 \\
\hline Floor (others) & -0.07 & -0.38 & -0.22 \\
\hline Indoor plumbing & 0.06 & 0.02 & 0.59 \\
\hline Electricity & 0.34 & 0.15 & 0.29 \\
\hline Toilet (public) & 0.06 & 0.12 & -0.92 \\
\hline Toilet (private) & 0.13 & 0.23 & 0.78 \\
\hline No toilet & -0.22 & -0.49 & 0.36 \\
\hline $\begin{array}{l}\text { Percent of Explained } \\
\text { Variance }\end{array}$ & 18.44 & 13.46 & 15.10 \\
\hline
\end{tabular}


Components shown in Table 3.7 can be used as variables in other hypothesis testing techniques such as a two-sample t-test to determine difference of means between two independent samples, such as stove owner groups, or regression analysis to determine, for example, if wealth measured by an MSL scale predicts adoption of the ahotor stove. ANOVA is used to analyze differences between groups with regard to MSL scores. A comparison of mean MSL principal component scores by respondent type reveals statistically significant differences between respondents with respect to household goods and luxury items (Figure 3.4).


Figure 3.4. Principal component scores for household goods and luxury items and respondent.

In Figure 3.4, the y-axis scale represents mean score for household goods and luxury items, respectively. The x-axis scale represents the type of respondent. The ahotor vulnerable household group scores lowest relative to household goods and 
luxury items, whereas the ahotor demonstration group score highest. The ahotor vulnerable household group is economically marginalized, as per criteria for their selection, therefore it is reasonable they score lowest on costlier household goods (television, refrigerator), building materials (metal roof) and luxury items such as a private toilet and indoor plumbing. According to theory, those who are first to adopt an innovation typically have control or access to substantial financial resources (Rogers, 1995). In this study, all but three respondents were given an ahotor stove that was fully subsidized. Respondents did not differ with respect to the house construction component scores $(\mathrm{F}=1.29, d f=3, \mathrm{n}=109, \mathrm{p}=0.28)$.

A Tukey's HSD (honest significant difference) test is used to calculate differences within treatment groups. Only statistically significant differences within groups is reported, refer to Table 3.8 and 3.9.

Table 3.8. Differences between groups with respect to Household goods.

\begin{tabular}{|l|c|c|c|}
\hline \multicolumn{1}{|c|}{ Respondent type } & Respondent type & Difference & P-Value \\
\hline $\begin{array}{l}\text { Ahotor demonstration } \\
\text { user group }\end{array}$ & $\begin{array}{l}\text { Ahotor vulnerable } \\
\text { household group }\end{array}$ & 0.94 & 0.05 \\
\hline
\end{tabular}

Table 3.9. Differences between groups with respect to Luxury items.

\begin{tabular}{|l|l|c|c|}
\hline \multicolumn{1}{|c|}{ Respondent type } & \multicolumn{1}{|c|}{ Respondent type } & Difference & P-Value \\
\hline Chorkor group & $\begin{array}{l}\text { Ahotor demonstration } \\
\text { user group }\end{array}$ & -0.99 & $<0.001$ \\
\hline $\begin{array}{l}\text { Ahotor } \\
\text { demonstration user } \\
\text { group }\end{array}$ & $\begin{array}{l}\text { Ahotor vulnerable } \\
\text { household group }\end{array}$ & 1.27 & 0.001 \\
\hline
\end{tabular}

The ahotor vulnerable household group (Table 3.8 and 3.9) score lowest relative to household goods and luxury items, whereas the ahotor demonstration user group score highest across these variables. For household goods, the difference is 
statistically significant (Table 3.8). Differences between groups with respect to luxury items are statistically significant (Table 3.9). Luxury items are defined by indoor plumbing, private toilet and a refrigerator (Table 3.7). These items are costly to purchase and maintain, therefore, it is likely that the ahotor demonstration group possesses more wealth-inferred by the MSL scale-than the chorkor and ahotor vulnerable household group.

\section{Innovation Attributes}

We investigate perceived attributes based on diffusion theory likely to predict adoption of stove innovations. The attributes are relative advantage, compatibility, complexity, trialability and observability. Refer to Table 3.10 for definitions of diffusion of innovation attributes and sub-variables. A positive or negative sign in parentheses next to each attribute indicates whether the attribute is positively or negatively related to adoption based on past investigations discussed by Rogers (1995). For example, the relative advantage of an innovation is positively related to adoption, whereas, complexity is negatively related to adoption (Rogers, 1995).

Each of the five attributes is measured by sub-variables. Sub-variables are scaled questions used to test the five perceived attributes of diffusion theory. The scaled questions are relevant to smoking technology. The direction of the scale is reversed for some variables to ensure directional continuity with other scales. For example, if cost is a barrier for buying an ahotor stove, a "yes" response would be a negative with respect to relative advantage. Each subset question compares the current stove to the previous stove used. Refer to Appendix E for construction of scales for each sub-variable in Table 3.10. 
Table 3.10. Attributes, subset of questions, and measurement for scale construction.

\begin{tabular}{|c|c|c|}
\hline Attribute $^{19}$ & Sub-variables & Measurement \\
\hline $\begin{array}{l}\text { Relative Advantage (+) } \\
\text { The extent to which an } \\
\text { innovation is perceived as } \\
\text { being better than the one } \\
\text { before it }\end{array}$ & $\begin{array}{l}\text { Do you use less fuelwood? } \\
\text { Do you spend less money on fuelwood? } \\
\text { How is the smoke nuisance to your eyes? } \\
\text { How is the breakage of fish? } \\
\text { How is the color of fish? } \\
\text { Is demand higher? } \\
\text { Does it cost less? } \\
\text { Is the cost of the stove a barrier to buy }{ }^{20} \text { ? } \\
\text { Is the cost worth the benefit? }\end{array}$ & $\begin{array}{l}\text { Dichotomous }^{21} \text { (Yes, No, } \\
\text { DK) } \\
\text { Dichotomous (Yes, No, DK) } \\
\text { 5-point Likert 22 } \\
\text { 5-point Likert } \\
\text { 5-point Likert } \\
\text { Dichotomous (Yes, No, DK) } \\
\text { Dichotomous (Yes, No, DK) } \\
\text { Dichotomous (Yes, No) } \\
\text { Dichotomous (Yes, No, DK) }\end{array}$ \\
\hline $\begin{array}{l}\text { Compatibility (+) } \\
\text { The extent to which an } \\
\text { innovation is consistent with } \\
\text { existing values, past } \\
\text { experiences and needs of } \\
\text { potential adopters }\end{array}$ & $\begin{array}{l}\text { Does it work well for types of fish you } \\
\text { process? } \\
\text { Is it easy to load trays? } \\
\text { Does it come with enough trays? } \\
\text { Do you need extra assistance? }\end{array}$ & $\begin{array}{l}\text { Dichotomous (Yes, No, DK) } \\
\text { Dichotomous (Yes, No, DK) } \\
\text { Dichotomous (Yes, No, DK) } \\
\text { Dichotomous (Yes, No, DK) }\end{array}$ \\
\hline $\begin{array}{l}\text { Complexity (-) } \\
\text { The extent to which an } \\
\text { innovation is perceived easy } \\
\text { or difficult to use }\end{array}$ & $\begin{array}{l}\text { How difficult is it to use? } \\
\text { Can you build it? } \\
\text { How difficult is it to find someone to build } \\
\text { it? } \\
\text { Is it easy to repair? }\end{array}$ & $\begin{array}{l}\text { 5-point Likert } \\
\text { Dichotomous (Yes, No, DK) } \\
\text { 4-point Likert }{ }^{23} \\
\text { Dichotomous (Yes, No, DK) }\end{array}$ \\
\hline $\begin{array}{l}\text { Trialability (+) } \\
\text { The extent to which an } \\
\text { innovation may be } \\
\text { experimented with or tested }\end{array}$ & $\begin{array}{l}\text { Did you get trained on it? } \\
\text { Did you get enough training until you were } \\
\text { satisfied? }\end{array}$ & $\begin{array}{l}\text { Dichotomous (Yes, No) } \\
\text { Dichotomous (Yes, No) }\end{array}$ \\
\hline $\begin{array}{l}\text { Observability }(+) \\
\text { The extent to which results of } \\
\text { an innovation are visible to } \\
\text { others }\end{array}$ & $\begin{array}{l}\text { Is it visible to others? } \\
\text { Do others ask you about it? } \\
\text { Is it noticeable to others that fish smoked by } \\
\text { your current stove looks different than fish } \\
\text { smoked by your previous stove? }\end{array}$ & $\begin{array}{l}\text { Dichotomous (Yes, No, DK) } \\
\text { Dichotomous (Yes, No, DK) } \\
\text { Dichotomous (Yes, No, DK) }\end{array}$ \\
\hline
\end{tabular}

We use principal component analysis to measure the underlying dimensions among sub-variables, or indicators likely to influence adoption of the ahotor stove. Principal component analysis takes a large number of variables (e.g. sub-variables or indicators shown in Table 3.10) and reduces them into a smaller set of variables,

${ }^{19}$ Defined by Rogers (1995).

${ }^{20}$ Score reversed to ensure directional continuity with other scales

${ }^{21}$ Dichotomous variables are scored 1 for positive or yes response, 0 for I don't know (DK), and -1 for no, or a negative response unless the scale is reversed where no is coded 1 and yes -1 .

22 -point Likert scale questions were scaled as +1 for much better, +0.5 for better, 0 for same, -0.5 for worse and -1 for much worse

${ }^{23} 4$-point Likert scale questions were created scaled as +1 for very easy, +0.5 for easy, -0.5 for difficult and -1 for very difficult. 
known as principal components. Principal component analysis is used to explore which variables in Tables 3.10 are interrelated. In other words, it looks for underlying meanings among variables.

Principal component analysis also looks for unrelated variables. For example, four of the 22 sub-variables or indicators manifest low $(<0.40)$ loadings across all components, so they are eliminated ${ }^{24}$ from the analysis and data are reanalyzed. The four items that are eliminated relate to difficulty of use (complexity), visibility of the stove to others (observability), visible differences of smoked fish (observability), and sufficient smoking trays (compatibility).

The scree test results in three components that account for 51.4 percent of the variance in the data (Table 3.11). Components are named according to the items included in them. Items with high positive loadings contribute more strongly to a positive component score than those with low or negative loadings.

A high negative loading subtracts from the overall component score but provides insights with respect to the interpretation of that component. Refer to Table 3.11 for component scores. Loadings are sorted by attributes (Table 3.11).

\footnotetext{
${ }^{24}$ Removal of these variables can simply mean they do not have enough in common, or are related, to other variables (Harlow, 2014).
} 
Table 3.11. Principal component analysis of Rogers (1995) attributes ( $\mathrm{n}=111)$.

\section{Attribute, sub-variables}

Relative advantage

Is the cost of the stove a barrier to buy?

Do you use less fuelwood?

Do you spend less on fuelwood?

How is the smoke nuisance to the eyes?

How is the color of fish?

How is the breakage of fish?

Is there higher demand?

Is the cost worth the benefit?

Does it cost less than the previous stove?

Compatibility

Is extra assistance needed?

Ease of loading trays

Does it work well for your types of fish?

Complexity

How difficult is it to find someone to

build the stove?

Can you build the stove yourself?

Is it easy to repair?

Observability

Do others ask you about your stove?

Trialability

Did you get trained to use the stove?

Did you get enough training?

Percent of Explained Variance

\begin{tabular}{|c|c|c|}
\hline Technology & $\begin{array}{c}\text { Product } \\
\text { differentiation }\end{array}$ & Labor \\
\hline $\begin{array}{c}\text { Variables and } \\
\text { Loadings } \\
\end{array}$ & $\begin{array}{c}\text { Variables and } \\
\text { Loadings }\end{array}$ & $\begin{array}{c}\text { Variable and } \\
\text { Loadings }\end{array}$ \\
\hline-0.75 & -0.07 & 0.08 \\
\hline 0.70 & 0.41 & 0.08 \\
\hline 0.66 & 0.35 & -0.00 \\
\hline 0.64 & 0.43 & 0.16 \\
\hline 0.19 & 0.71 & -0.07 \\
\hline-0.38 & 0.69 & 0.15 \\
\hline 0.21 & 0.60 & 0.10 \\
\hline-0.11 & 0.47 & -0.05 \\
\hline 0.02 & -0.47 & 0.03 \\
\hline-0.01 & -0.02 & 0.84 \\
\hline 0.04 & 0.20 & 0.80 \\
\hline-0.10 & 0.45 & -0.55 \\
\hline-0.73 & 0.21 & -0.20 \\
\hline-0.57 & 0.13 & -0.03 \\
\hline-0.56 & 0.31 & 0.03 \\
\hline 0.66 & -0.02 & 0.18 \\
\hline 0.73 & -0.06 & -0.05 \\
\hline 0.72 & 0.02 & -0.10 \\
\hline 26.64 & 14.77 & 9.99 \\
\hline
\end{tabular}

Technology component contributes most to the variance in the data (Table

3.11). This component is named technology because it is characterized by positive and negative loadings reflecting a stove's design, interest expressed by others about the ahotor stove, instructions (e.g. training on its use), cost and construction. High positive loadings for this component relate to a stove's design, instructions related to use or training. For example, high positive loadings include less fuelwood consumption, less money spent on fuelwood and less smoke nuisance to the eyes. 
These items potentially provide economic and non-economic benefits. Economic profitability is associated with relative advantage, a perceived attribute according to diffusion theory (Rogers, 1995). High positive loadings for this component also relate to satisfactory training on use of a stove and interest (in the stove) expressed by others. Training is important to diffusion of innovations because it reduces uncertainty (Rogers, 1995). Training is associated with trialability, a perceived attribute according to diffusion theory (Rogers, 1995). Innovations that are visible to others are associated with observability, another perceived attribute according to diffusion theory (Rogers, 1995).

High negative loadings on the first component relate to a stove's cost and construction. High cost (of an innovation) is a disadvantage according to diffusion theory (Rogers, 1995). On average, the ahotor stove ${ }^{25}$ costs twice as much the chorkor stove to build (SFMP, personal communication, June-August, 2017). Items related to construction (of a stove) load high negative on the technology component. Difficulty building, repairing or finding someone to construct a stove is associated with complexity, the only perceived attribute according to diffusion theory that is negatively correlated with adoption of an innovation (Rogers, 1995). At the time of this study, nine artisans were trained to build the ahotor stove in Ghana (SFMP, personal communication, June-August, 2017).

The second component is named product differentiation, a term borrowed from Porter (1985) and defined as a type of competitive advantage. High positive loadings for this component relate to important features of smoked fish products in the

${ }^{25}$ Single unit ahotor stove with ten trays costs 1,280 Cedis ( 270 USD). 
marketplace, such as color, breakage and demand of fish. High positive loadings for product differentiation also relate to equipment or technology used to smoke fish, such as less consumption of fuelwood and smoke nuisance (Table 3.11).

The third component is termed labor because the highest positive loadings relate to it. Extra assistance and ease of loading trays depends on the amount of fish being smoked, which in this case, coincided with the peak fishing season. We posit ease of use (of machinery) depends on the degree of physical labor involved. Ease of use is associated with complexity and compatibility, the fifth perceived attribute according to diffusion theory (Rogers, 1995).

Analysis of between-stove differences among the three components (technology, product differentiation and labor) indicates the only statistically significant difference is found with regard to technology. Refer to Table 3.12. Aspects of technology that differentiate the ahotor stove from the chorkor stove are less consumption of fuelwood, less money spent on fuelwood, and less smoke nuisance.

Table 3.12. Innovation attributes component scores across user groups. ${ }^{26}$

\begin{tabular}{|l|c|r|r|c|}
\hline \multirow{2}{*}{ Variable } & Respondent type & Mean & $\mathrm{N}$ & $\mathrm{t}$ \\
\hline \multirow{2}{*}{ Technology } & Chorkor & -0.67 & 63 & \multirow{2}{*}{$-12.41^{*}$} \\
\cline { 2 - 4 } $\begin{array}{l}\text { Product } \\
\text { differentiation }\end{array}$ & Ahotor & 0.87 & 48 & \\
\cline { 1 - 4 } Labor & Ahorkor & 0.09 & 63 & \multirow{2}{*}{1.12} \\
\cline { 2 - 4 } & Chorkor & -0.12 & 48 & \multirow{2}{*}{-1.17} \\
\hline
\end{tabular}

${ }^{*}$ p-Value $<0.001$ (based on Student's t-test, two-tailed)

Binary logistic regression is used to investigate whether socio-demographic, attitudinal or innovation attributes predict future adoption of the ahotor or chorkor

${ }^{26}$ User groups are classified by the type of stove the survey questions are based on. 
stove. Logistic regression is a multivariate prediction method. It is used to estimate models for binary, dependent variables using both continuous and categorical independent variables. The goal is to test whether the set of independent variables is significantly related to the dichotomous dependent variable (chorkor=0; ahotor=1), the ahotor or chorkor stove. Eleven independent or predictor variables are selected based on previous fishing-equipment related studies (Dewees \& Hawkes, 1988; Tango-Lowy \& Robertson, 2002). All independent variables meet assumptions for normality and linearity except cosmopolitanism. A log transformation is conducted on this binary variable to satisfy assumptions.

The overall model is statistically significant $(\mathrm{p}-$ Value $=<0.001, \mathrm{df}=11$, Naglekerke's R-squared $=0.85$ ). Refer to Table 3.13. According to this model, predictor variables that influence adoption of the ahotor stove are technology and luxury items, a proxy for wealth measured by an MSL scale (Table 3.7). The variable that statistically predicts adoption of the ahotor stove best is technology defined by less fuelwood consumption, less money spent on fuelwood, less smoke nuisance to the eyes, interest expressed by others about the stove, and instructions or training on use of the stove (Table 3.13). Luxury items, a proxy for wealth also predicts adoption of the ahotor stove (Table 3.13). 
Table 3.13. Logit coefficients from model of adoption of ahotor stove.

\begin{tabular}{|l|c|c|}
\hline \multirow{2}{*}{\multicolumn{1}{|c|}{ Variable }} & \multicolumn{2}{c|}{ Ahotor stove } \\
\cline { 2 - 3 } & Coef. & Std error \\
\hline Age & 0.00 & 0.07 \\
\hline Years' experience smoking fish & -0.04 & 0.05 \\
\hline Financial literacy & -1.90 & 1.19 \\
\hline Cosmopolitanism & -0.23 & 2.94 \\
\hline Household goods & 0.86 & 0.68 \\
\hline House construction & $0.93^{* * *}$ & 0.54 \\
\hline Luxury items & $1.71^{* *}$ & 0.73 \\
\hline Availability of wood (today-past) & -0.24 & 0.22 \\
\hline Technology & $3.79^{*}$ & 0.91 \\
\hline Product differentiation & 0.33 & 0.53 \\
\hline Labor & 0.11 & 0.48 \\
\hline Constant & -0.30 & 2.74 \\
\hline
\end{tabular}

Coefficients significant at $<0.001$ level $^{*}, 0.05$ level $^{* *}$ and 0.10 level $^{* * *}$.

\section{Relevance of Quantitative Results to Theory}

This study examines perceived attributes of innovations consistent with diffusion theory. They are relative advantage, compatibility, complexity, observability and trialability (Rogers, 1995). This study concludes that a combination of perceived attributes influence adoption of the ahotor stove in Ghana. Tables 3.11, 3.12 and 3.13 suggest technology plus simplicity will influence adoption of the ahotor stove in Ghana. Simplicity is the opposite of complexity measured by construction and repairs to stoves in this study. According to diffusion theory, complexity is the only attribute negatively correlated with adoption (Rogers, 1995). Innovations that are simple to understand and use are adopted more rapidly according to Rogers (1995). Rogers (1995) states innovations are classified as two extremes along a spectrum, complex or simple, but does not provide metrics or measurements to determine classification along the continuum. This study measured complexity on a scale. 
High positive and negative component loadings for technology shown in Table 3.11 reflect consistency with diffusion theory. For example, high positive loadings for technology include less money spent on fuelwood, a direct economic benefit associated with relative advantage in diffusion theory. Less smoke nuisance (result of design) is a non-economic benefit associated with relative advantage. This finding supports Roger's (1995) proposition that more non-economic factors are needed to understand different motivations for adopting an innovation. High positive loadings on training are positively correlated with adoption because they reduce uncertainty according to diffusion theory (Rogers, 1995). Items loading high negative on the first component shown in Table 3.11 relate to complexity. Low initial cost is a relative advantage in diffusion theory, which is confirmed in this study because the cost of a stove is a barrier to adoption (the highest negative loading in Table 3.11).

A seminal meta-analysis ${ }^{27}$ of innovation attributes conducted by Tornatzky \& Klein (1982) concluded relative advantage and compatibility were consistently positively correlated with adoption, whereas complexity was negatively correlated with adoption. The Tornatzky \& Klein (1982) study was critical of other studies that only examined one or few attributes in a given study stating "single characteristic studies are not particularly useful for the purpose of clarifying the relative predictive power of attributes" and called for the need to examine several innovation attributes within a study (Tornatzky \& Klein, 1982, p.32). This study identifies that several innovation attributes combined into one meta-variable termed technology predict adoption.

\footnotetext{
${ }^{27}$ Seventy-five studies were analyzed and in almost one half of the studies, only one innovation characteristic was examined (Tornatzky \& Klein, 1982).
} 
Differences in mean scores between stove types for each innovation attribute component is shown in Table 3.12. The only statistically significantly difference (pValue $<0.001$ ) between stoves by innovation attributes is found with respect to technology (Table 3.12).

A logistic regression model suggests technology (coefficient significant at $<$ 0.001 ) and luxury items (coefficient significant at $<0.05$ ), a proxy for wealth, predict adoption of the ahotor stove (Table 3.13). Coefficients in this model indicate the stove's attributes more so than socio-economic (and attitudinal) variables increase likelihood of adopting the ahotor stove. According to diffusion theory, those first to adopt an innovation (e.g. innovators) typically have control of substantial financial resources (Rogers, 1995).

\section{Environmental, Economic, and Health Perceptions}

We measure environmental, economic and health perceptions of the ahotor stove among fish processors.

Fish and fuelwood are primary inputs needed to smoke fish. Perceptions regarding changes to their availability-past, present and future-may reveal how users view environmental attributes associated with new smoking technology. The technique chosen for this measurement is a visual, self-anchoring ladder-like scale (Cantril \& Livingston, 1963) which allows for making finer ordinal judgements, places little demand on the respondent's short-term memory. In this study, both the ahotor and chorkor treatment groups are shown ladder-like diagram with 10 steps (See Appendix F). The respondent is told that the first step represents the worst possible conditions. For example, with respect to the availability of fuelwood, the worst 
possible condition is when you have to travel further to get wood, pay more, or delay smoking fish because fuelwood is scare or expensive. The highest step was described as the opposite of the worst, or when fuelwood is plentiful and easy to get and you do not need to pay more for it because it is abundant. The respondent is then asked where on this ladder availability of fuelwood is today, 5 years ago and 5 years in the future. This technique is repeated with a similar example for availability of fish. After pretesting the diagram, pictures of fuelwood and fish are added next to each step to indicate availability and facilitate comprehension.

Analysis of variance is used for differences between group means with respect to change in availability of fish and fuelwood (Table 3.14). Table 3.14 indicates that there are no statistically significant differences between the 4 groups except for availability of fuelwood today versus 5 years ago $\left(\right.$ Fuelwood $\left._{\mathrm{T2}-\mathrm{T} 1}\right)$. The ahotor demonstration user and chorkor groups see less of a difference regarding availability of fuelwood today versus 5 years ago than ahotor vulnerable households and nonadopters (Table 3.14). 
Table 3.14. Analysis of perceived changes of availability of fish and fuelwood.

\begin{tabular}{|c|c|c|c|c|c|c|c|c|c|c|c|}
\hline \multirow{2}{*}{ Variable } & \multicolumn{2}{|c|}{$\begin{array}{c}\text { Ahotor } \\
\text { Demonstration }\end{array}$} & \multicolumn{2}{|c|}{$\begin{array}{c}\text { Ahotor } \\
\text { Vulnerable } \\
\text { household }\end{array}$} & \multicolumn{2}{|c|}{ Chorkor } & \multicolumn{2}{|c|}{$\begin{array}{c}\text { Ahotor non- } \\
\text { adopter }\end{array}$} & \multirow[b]{2}{*}{$\begin{array}{c}\text { Squared } \\
\text { Multiple } \\
\text { R } \\
\end{array}$} & \multirow[b]{2}{*}{$\begin{array}{c}\mathrm{F} \\
\text { Ratio }\end{array}$} & \multirow[b]{2}{*}{$\begin{array}{c}\text { Effect } \\
\text { size }\end{array}$} \\
\hline & Mean & $\mathrm{N}$ & Mean & $\mathrm{N}$ & Mean & $\mathrm{N}$ & Mean & $\mathrm{N}$ & & & \\
\hline Fuelwood $_{\mathrm{T} 2-\mathrm{T} 1}$ & -1.793 & 29 & -4.200 & 10 & -2.000 & 63 & -5.000 & 9 & 0.125 & $5.105^{*}$ & Large \\
\hline Fuelwood $_{\text {T3-T2 }}$ & -1.517 & 29 & -2.500 & 10 & -2.079 & 63 & -2.111 & 9 & 0.029 & 1.056 & - \\
\hline Fish $_{\mathrm{T} 2-\mathrm{T} 1}$ & -3.276 & 29 & -4.900 & 10 & -3.429 & 63 & -4.444 & 9 & 0.050 & 1.876 & - \\
\hline Fish $_{\mathrm{T} 3-\mathrm{T} 2}$ & -1.069 & 29 & -2.700 & 10 & -1.613 & 62 & -2.667 & 9 & 0.053 & 1.996 & - \\
\hline
\end{tabular}

T2-T1 = Availability today - past.

T3-T2 = Availability future - today.

${ }^{*} \mathrm{p}<0.01$, df $=3$.

For ANOVA, $R^{2}$ is used for effect size indicator.

A Tukey's test is used to calculate differences within the ahotor and chorkor groups. Table 3.15 shows statistically significant differences between the ahotor and chorkor groups with respect to perceived changes of availability of fuelwood today versus 5 years ago (FuelwoodT2-T1).

Table 3.15. Differences between ahotor and chorkor groups regarding Fuelwood $\mathrm{T}_{\mathrm{T} 2 \mathrm{~T} 1}$.

\begin{tabular}{|c|c|c|c|c|}
\hline Respondent type 1 & Respondent type 2 & Difference & P-Value & CI (lower,upper) \\
\hline $\begin{array}{c}\text { Chorkor } \\
\text { Ahotor } \\
\text { Demonstration }\end{array}$ & Ahotor non-adopter & 3.00 & 0.014 & $0.46,5.54$ \\
\hline
\end{tabular}

The perception of greater change in availability of fuelwood among ahotor non-adopters is not a compelling reason to adopt fuelwood-efficient technology (Table 3.14). Ahotor vulnerable households demonstrate least control of substantial financial resources with respect to MSL variables (Figure 3.4) and cite lack of working capital needed to smoke fish (Table 3.3). Hence, their perception may be 
informed by price (of fuelwood), an additional financial burden for those living at the margin.

\section{Economic}

Perceived economic benefits of improved fish smoking stoves are measured according to three variables; cost of fuelwood, sales and quality of smoked fish. In the ahotor group, an overwhelming majority of beneficiaries (95\%) state less money is spent on fuelwood using the ahotor versus the chorkor stove, whereas 5 percent do not know (Table 3.16). Responses within the chorkor group are more evenly divided (Table 3.16). The difference is statistically significant.

Table 3.16. Expense of fuelwood by respondent type.

\begin{tabular}{|c|c|c|c|}
\hline \multirow{2}{*}{$\begin{array}{c}\text { Do you spend less money } \\
\text { on fuelwood? }\end{array}$} & \multicolumn{3}{|c|}{ Respondent type (\%) } \\
\hline & Chorkor group & Ahotor group & $\mathrm{N}$ \\
\hline No & 33.33 & 0.00 & 21.00 \\
\hline I don't know & 22.22 & 5.13 & 16.00 \\
\hline Yes & 44.44 & 94.87 & 65.00 \\
\hline Total & 100.00 & 100.00 & \\
\hline $\mathbf{N}$ & 63.00 & 39.00 & 102.00 \\
\hline
\end{tabular}

Respondents are asked if fish smoked by their current stove sells faster at the market than fish smoked by their previous stove. Data are transformed into two groups, yes and no or do not know due to low cell frequency counts in resultant tables $(<6)$. Within the ahotor group, 66.7 percent state fish sells faster at the market, whereas 33.3 percent state no or they do not know. Within the chorkor group, respondents state 47.6 and 52.3 respectively. The difference is statistically significant (Table 3.17). 
Table 3.17. Sales of fish at the market by stove type.

\begin{tabular}{|l|r|r|r|}
\hline \multirow{2}{*}{$\begin{array}{c}\text { Does fish from ahotor? } \\
\text { sell faster at the market? }\end{array}$} & \multicolumn{3}{|c|}{ Respondent type (\%) } \\
\cline { 2 - 4 } & Chorkor group & Ahotor group & \multicolumn{1}{c|}{ N } \\
\hline No or I don't know & 52.38 & 33.33 & 47.00 \\
\hline Yes & 47.62 & 66.67 & 58.00 \\
\hline Total & 100.00 & 100.00 & \\
\hline N & $\mathbf{6 3 . 0 0}$ & $\mathbf{4 2 . 0 0}$ & $\mathbf{1 0 5 . 0 0}$ \\
\hline
\end{tabular}

Chi-square value $=3.70, d f=1, p$-Value $=0.05$

Fisher Exact Test two-tailed $p=0.07, n=105$

Owners of the ahotor stove are trained to separate-not mix-fish smoked by different types of stoves and sold at the market. The SFMP-led trainings may have some influence on this practice (i.e. not to mix fish) and contribute to differences between groups.

Respondents compared quality of smoked fish by stove types with use of a scale. ${ }^{28}$ An ordinal rank test reveals statistically significant differences between stoves with respect to quality of smoked fish (Kruskal-Wallis $=6.72$, $\mathrm{df}=1, \mathrm{p}=0.01$ ). A twosample t-test of the mean demonstrates the difference is statistically significant $(t=-$ 2.69, $\mathrm{df}=103, \mathrm{p}-$ Value $=0.008)$. Refer to Table 3.18 for descriptive statistics. The median score for the ahotor group is 1.00 and .50 for the chorkor group. The ahotor group perceived much better quality of smoked fish by stove type than the chorkor group. This finding is also consistent with the goal behind the design of the ahotor stove.

\footnotetext{
285 -point Likert scale question was scaled as +1 for much better, +0.5 for better, 0 for same, -0.5 for worse and -1 for much worse.
} 
Table 3.18. Perception of quality of smoked fish by respondent type.

\begin{tabular}{|c|c|c|}
\hline \multirow{2}{*}{$\begin{array}{c}\text { How is the quality of } \\
\text { smoked fish with your } \\
\text { current stove? }\end{array}$} & \multicolumn{2}{|c|}{ Respondent type } \\
\hline & Chorkor & Ahotor \\
\hline Minimum & -1.00 & -0.50 \\
\hline Maximum & 1.00 & 1.00 \\
\hline Median & 0.50 & 1.00 \\
\hline Mean & 0.53 & 0.77 \\
\hline $\mathbf{N}$ & 63 & 42 \\
\hline
\end{tabular}

\section{Health}

Improved fish smoking technology is associated with personal health benefits such as less exposure to direct smoke. The majority of those using the ahotor stove experience less coughing while using it compared to previous stoves (Figure 3.5). Irritated eyes (i.e. red, watery eyes) is commonly noted among respondents.

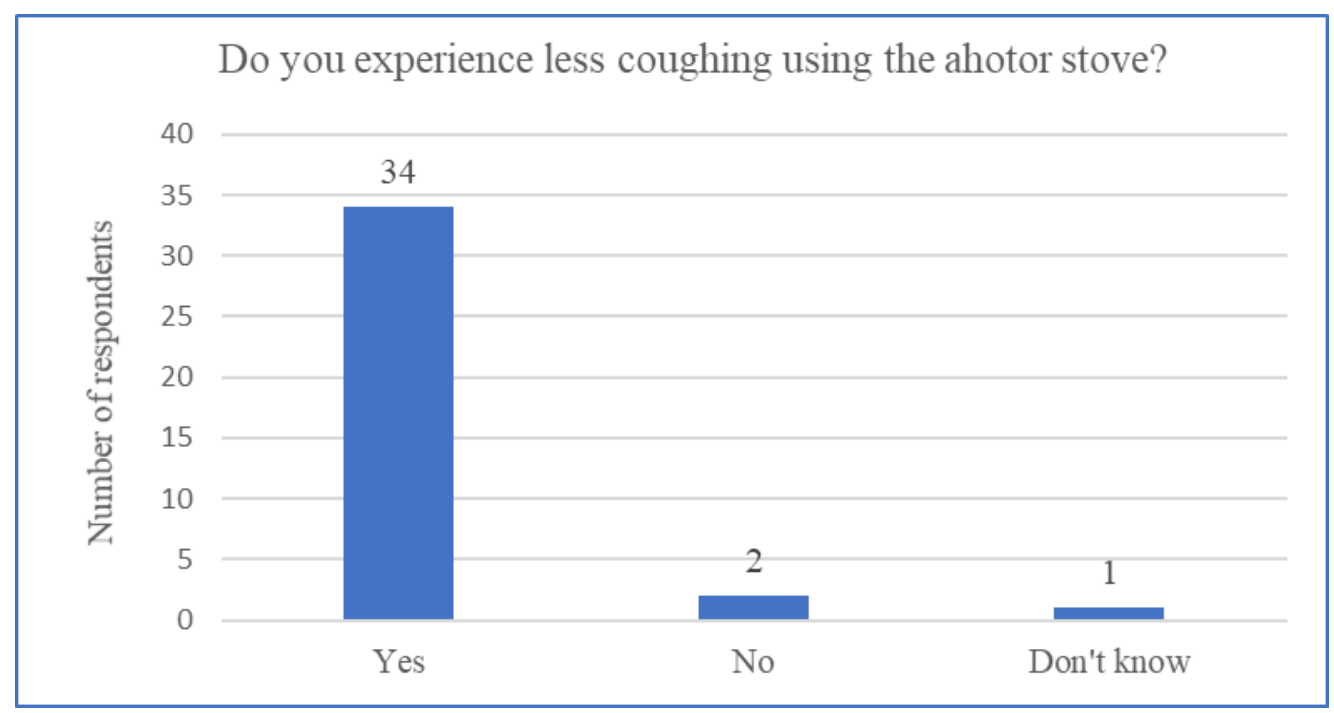

Figure 3.5. Coughing in relation to the ahotor stove. 


\section{Discussion}

There are clear differences between the ahotor and chorkor stove according to fish processors in Ghana. In order to understand what stands in the way of widespread adoption of the ahotor stove, we discuss these findings more closely, recognize implementation gaps, and try to understand the beneficiaries we target-and capturethrough extension. Findings are discussed in the context of diffusion theory, development and extension practices.

Rogers (1995) did not foresee that a combination of any five perceived attributes (relative advantage, compatibility, complexity, observability, and trialability), into one meta-variable could predict adoption. Rogers (1995) also recognizes that these five attributes may not be the most important characteristics for a specific group of respondents. Other studies have built on or replaced Rogers' perceived attributes with new constructs, or scales to predict adoption of innovations in the health education and information technology sector (Moore \& Benbasat, 1991; Steckler, Goodman, McLeroy, Davis, \& Koch, 1992; Pankratz, Hallfors, \& Cho, 2002). The most notable methodological contribution discussed by Rogers (1995) came from Moore \& Benbasat (1991). Moore \& Benbasat (1991) created eight scales, replacing complexity with ease of use and adding others such as voluntariness and image through an exhaustive instrument development process applicable to any innovation. Replacing complexity with simplicity as a means of measuring adoption is also recommended as a result of this study.

In this study, attributes of stove technology plus simplicity and attributes of fish smokers such as possession of luxury items, a proxy for wealth predict adoption of the ahotor stove in Ghana (Table 3.13). Technology is defined by less consumption 
and cost of fuelwood and smoke nuisance which are positive attributes, but it is also defined by complexity measured by cost and construction that negatively influence adoption of innovations. Rogers (1995) uses the word “innovation” and “technology” as synonyms. Merriam-Webster defines technology as "the use of science in industry to invent useful things or to solve problems." The ahotor stove is designed ${ }^{29}$ to consume less fuelwood. A controlled experiment presented in Appendix B and discussed earlier in this paper confirms the ahotor stove is more fuel-efficient than the chokor stove. The difference is statistically significant $(\mathrm{t}=9.513, \mathrm{df}=2)$. A high positive loading for fuel-efficiency in Table 3.11 reflects a statement made by one respondent who notes "the ahotor uses 4 sticks of wood, whereas the chorkor uses twice as much, or 8 sticks of wood.” These findings mirror the definition of technology but also support specific recommendations made by the FAO through its Guidelines ${ }^{30}$ and toward achieving goals outlined by the United Nation's 2030 Agenda for Sustainable Development. $^{31}$

All things being equal, consuming less fuelwood results in lower costs per unit (of smoked fish). On average, processors using the ahotor stove can expect to spend 33 percent less on fuelwood per week in the peak season than those using a chorkor stove (Kwarteng, 2016). The majority of respondents using the ahotor stove perceive they spend less money on fuelwood (Table 3.16). A high positive loading for this variable contributes to the first component in Table 3.11. Perceptions among

\footnotetext{
${ }^{29}$ Fuelwood is placed on an elevated grate inside a small combustion chamber with primary and secondary air inlets to help it burn more efficiently.

${ }^{30}$ Deter waste of inputs (water, fuelwood) in small-scale fish handling and processing (FAO, 2015, Section 7.5).

${ }^{31}$ Access to clean cooking fuels and technologies (United Nations, 2016, Goal 7).
} 
respondents such as "fuelwood is very expensive now" and "hard to get" validate the status of this resource.

A high positive loading for smoke nuisance contributes to the first component, technology, in Table 3.11. The majority of those using the ahotor stove cite less coughing while smoking fish (Figure 3.5). Smoke, regardless of its source, is unhealthy. Fish processors have been exposed to smoke for many years. The average number of years processing fish among the chorkor group is 31, or more than half their age on average. Fish processors recognize the impact it has on their health. As one respondent states "people do say the smoke makes your heart black," while another accepts "we are used to smoke, we have no choice." The ahotor stove is equipped with a roof that has a hole to direct smoke away from the operator. Yet, with so many stoves producing smoke nearby, it is difficult to attribute less coughing by type of stove as one respondent observes. New research indicates dermal adsorption of PAHs may be a more significant intake pathway than inhalation, but not more than ingestion (Lao, Xie, Wu, Bao, Tao, \& Zeng, 2018).

Exposure to PAHs while smoking fish is not only an occupational health risk within this node, but it is also a dietary or food safety issue for those who consume smoked fish with high levels of PAHs. Specific design features of the ahotor stove such as a drip collector and combustion system appear to reduce levels of PAHs in smoked fish compared to other stove types based on a very limited sample (Figure 3.1). To-date, only one sample test shows the ahotor stove meets the European Union maximum residue limit for PAHs. It is premature to determine whether the ahotor stove will comply with EU PAHs requirements, however, the USAID/SFMP is 
conducting subsequent studies on levels of PAHs with the Ghana Standards Authority to establish consistent results showing lower PAHs levels and potential compliance with EU PAHs requirements. To-date, the ahotor stove design shows lower levels of PAHs in smoked fish than other stove designs such as the chorkor and morrison stove. The Guidelines advocate producing good quality and safe fish products for both markets (FAO, 2015). Efforts to comply with these recommendations warrant more attention with respect to food safety, especially linked to controlling PAHs in smoked fish. Additional research is needed to understand the impacts of PAHs on consumers of smoked fish in West Africa and elsewhere traditional smoking techniques are used.

Innovations that are easily observed (and communicated) to others are positively correlated with adoption according to theory. One of the variables measured according to this attribute relates to inquiry (by others) about the stove and contributes to the first component, technology, in Table 3.11. For example, two respondents asked “is it (ahotor) used to bake bread?" While another asks how does "the new stove in town" process fish? Questions such as these suggest the innovation may not be so apparent (to others).

According to theory, knowledge of an innovation is gained during the first stage of the innovation-decision process (Rogers, 1995). At the knowledge stage, an individual or group is introduced to an innovation and gains some understanding of its function through communication channels (mass media or interpersonal) and change agents (i.e. USAID/SFMP). The most relevant types of knowledge discussed by Rogers (1995) that relate to this study are how-to-use the innovation properly and principles underlying the purpose and function of the innovation. For example, if the 
innovation is complex, there should be more emphasis placed on the how-to-use the innovation according to diffusion theory (Rogers, 1995). Similarly, understanding the underlying principle which in this case is energy efficiency will prevent discontinuance and mis-use of the innovation. Finally, some individuals are more predisposed to acquiring knowledge given their socio-economic status, such as higher education, greater exposure and access to media channels and change agents (Rogers, 1995).

Training reduces uncertainty especially in the early stages of diffusing an innovation. High positive loadings on questions related to training contribute to the first component, technology, in Table 3.11. Ahotor stove demonstration trainings are part of the intervention package under the SFMP. The chorkor stove has been promoted for decades and transfer of knowledge is generational according to statements made by fish processors who learned how to use it from their mothers, relatives and neighbors. Interestingly, 63 percent of those using the ahotor first heard about the stove through peer-to-peer contact. Given the nature of this work (e.g. generational) and high rate of illiteracy in fishing communities, relying on interpersonal communication channels is a logical and cost-effective means of communicating an innovation. There is also a relationship between communication channels and perceived attributes of innovations according to diffusion theory (Rogers, 1995). For example, interpersonal contact is more important than mass media channels with respect to relative speed of adoption for innovations that are perceived as complex (Rogers, 1995). 
High negative loadings in the first component, technology, in Table 3.11 relate to a stove's complexity measured by construction and maintenance. The two stoves differ significantly with respect to this attribute. At the time of the study, nine artisans were trained to build the ahotor stove in Ghana. According to statements made by respondents using the ahotor stove, this presents a challenge. As one respondent stated, "they have to call a project partner under the SFMP to come and build the stove for them," while another commented "you have to go and ask for the telephone number of an artisan because there is no one in the community who can build it." Another respondent explained that a local chorkor artisan who came to look at the ahotor stove said it was "too complicated for him to build." Recently, the USAID/SFMP acknowledged this problem and is training more artisans to build the ahotor stove in Ghana (D. Owusu, personal communication, April 26, 2018).

The highest negative loading in the first component in Table 3.11 is related to cost suggesting cost is a barrier to adoption of stove technology. Conversely, presence of or access to luxury items is a variable used to predict adoption (Table 3.13). The ahotor stove costs approximately twice as much as its predecessor, the chorkor stove. The Guidelines advocate post-harvest processing innovations should be cost-efficient (FAO, 2015, Section 7.5). At the time of this study, only three respondents had selffinanced the purchase of an ahotor stove. In this study, respondents that own the ahotor stove were asked how long it would take for the stove to pay for itself. Sixtythree percent stated it would take one year or less for this stove to pay for itself, 30 percent stated it would take more than one year and 7 percent did not know $(n=43)$. 
This information is useful to financing institutions that extend loans to fish processors in Ghana.

Financing options are available to fish processors through microfinance institutions, such as the Microfinance and Small Loans Centre (MASLOC). MASLOC is responsible for implementing the Government of Ghana's poverty reduction programs. There is a MASLOC office in every district in Ghana that extends small loans from 1,000 to 10,000 Cedis to support the development of small-scale businesses. Microfinance is helpful; however, the cost of a stove is clearly a hurdle that may cause sticker shock. Affordability is a constraint for diffusion of technology in developing countries discussed by James (2013). Given what we have learned from this study with respect to perceived attributes of innovation according to diffusion theory, we suggest a change in diffusion terminology. We suggest replacing complexity with simplicity so this attribute reflects a positive correlation with adoption similar to other attributes such as relative advantage, compatibility, trialability, and observability, instead of being the only attribute negatively correlated with adoption. Re-wording this attribute creates a conditional statement, expressed as, if an innovation is simple, then it is more likely to be adopted. The purpose behind creating this statement is to guide practice, for example, if post-harvest fish processing innovations are simple to use and understand, then they are more likely to be adopted. In this study, an innovation that is simple to use and understand is a stove that is easy to build and repair. Complexity of using fish finding technology (e.g. chronoscope and track plotter) by fishermen in the Pacific Coast Trawl Fishery was considered a barrier 
to adoption by Dewees \& Hawkes (1988). Moore \& Benbasat (1991) replaced complexity with ease of use.

The ahotor stove is an innovation designed to upgrade the post-harvest fish processing sector in Ghana. This sector is dominated by women who primarily process and market low-value marine species for local and regional trade. However, two of the three $^{32}$ respondents who self-financed the purchase of this stove are male, aquaculture farmers. The stoves are used to smoke tilapia. Both farmers live and work in Ashanti, a non-coastal region of Ghana. Interestingly, there is no development extension work conducted under the USAID/SFMP in this region, nor within the aquaculture sector. Both farmers display dominant characteristics of innovators defined by diffusion theory (Rogers, 1995). Based on a key informant interview and direct observation, both farmers have access to substantial financial resources and appear risk-tolerant. One of the farmers purchased a quadruple-unit ahotor stove, while the other recently ventured into this sector after a career in journalism. An in-depth interview with one of the two farmers is located in the text box.

\section{Interview with a tilapia farmer using the ahotor stove}

Kofi is a 61-year old fish farmer in the Ashanti Region of Ghana using the ahotor stove. This is an industrious land-locked region known for farming (i.e. cocoa, palm oil, and fish including tilapia and catfish), timber, and mining (i.e. gold and diamonds). There are approximately 400 small-scale fish farmers registered with the regional Fisheries Commission office in Kumasi, the capital of this region and second largest city in Ghana. The role of the Fisheries Commission in this region is to help fish farmers develop and operationalize their businesses in addition to providing regulatory oversight. The local university, Kwame Nkrumah University of Science and Technology (KNUST) has a wellestablished aquaculture department. Fish farming is a growth industry in this region and farmers have access to scientific and regulatory institutions.

Kofi, however, does not fit the typical profile of a Ghanaian fish processor. He is male and processes fish far from the coast. Kofi is a retired journalist who ventured into farming because it seemed like " $a$ very quiet job." Kofi lives and works in a large, private compound surrounded by teak forests, almond

${ }^{32}$ The third respondent that self-financed with ahotor stove was also a male who worked for the USAID/SFMP project, although the stove was used by his wife, a marine fish processor. 
trees and tilapia ponds. Every morning, Kofi feeds his fish and then goes back to writing as a hobby. As a farmer, Kofi is concerned about post-harvest loss of fish due to spoilage. He would like to improve the quality of his fish and was thinking about ways to add value to his product because "when you have fish it rots and fishmongers want to buy it cheap, instead of selling them rotten fish, I decided to start smoking it."

In early 2017, Kofi came across an advertisement in the Daily Graphic, a national newspaper, that talked about a new fish processing stove called ahotor and how this stove reduces post-harvest loss of fish in other regions of Ghana. Such advertisements are part of the USAID/SFMP's mass communication messaging strategy, albeit not directed at this region, nor sector. Intrigued by the advertisement given his concerns with post-harvest loss, Kofi contacted the Business Advisory Council (similar to a Chamber of Commerce) who introduced him to a USAID/SFMP project partner (i.e. SNV)

Within 2 weeks, Kofi had met with SNV to discuss details of purchasing and delivering the ahotor stove and secured a bank loan for 2,200 cedis to pay for it. The loan was paid off in 3 months from his own line of credit, not from fish sales. However, Kofi believes fish smoking will contribute to 40 percent of his household income in the future. His business strategy is to wait until all the "bad, cheap fish is off the market, harvest his fish ponds in September (2017) and sell into the market in December when supply of fish is low." Kofi has been using the ahotor stove with fish from the cold storage and sends smoked fish to the market with women because in Ghana they say "market women, not market men.” Kofi believes tilapia smoked by the ahotor stove will sell faster at the market because it is "well smoked, more palatable and sumptuous looking."

- Interview conducted on July 18, 2017 in Ashanti region

This is an example of unintended, yet beneficial, consequence of upgrading aquaculture farmers by diffusing an innovation designed for the marine capture fisheries value chain in Ghana. This may lead to diffusion of the ahotor stove within a new node (e.g. tilapia farmers). The aquaculture sector in Ghana is growing at a rate of 10 percent year primarily through production of tilapia, which accounts for 90 percent of aquaculture production (FAO, 2016).

The innovation, however, failed to benefit some it targeted. For example, onefifth of those who own the ahotor stove had not adopted it despite being fully subsidized. Non-adoption occurred for various reasons shown in Table 3.3. One reason suggests a gap in implementation. We learned that two beneficiaries were not using the stove at the time of the study due to missing parts, or incomplete delivery of the stove. For them, the new technology was not fully assembled nor ready for use. 
The "implementation gap" in the context of coastal management policy and practice is characterized by Lowry (1985) as essentially a disconnect between the design and execution of a program. While this is an acute example of a gap in implementation (that was rectified as a result of this study), we also observed no improvising to compensate for missing components, not even a grate. This leads to other reasons for non-adoption identified in this study such as lack of working capital to purchase fish and fuelwood, no land to build a stove and lack of preferential markets to sell fish smoked by the ahotor stove. These reasons give us a lens into the problems facing many poor and why they may perceive the risk (of an innovation) higher than its reward.

Vulnerable households provisioned with an ahotor stove demonstrate least possession of wealth, inferred from an MSL scale (Figure 3.4). While this is consistent with criteria used to select this group of under the SFMP, we also learned that some fish processors were not able to benefit from this stove because they simply did not have sufficient working capital to purchase primary inputs needed to smoke fish nor did they own land to place a fixed asset (Table 3.3). This depicts a "poverty trap," or remaining in poverty because one has too little to invest. It is the beginning of a cycle that leads to a poverty trap zone $e^{33}$ discussed by Banerjee \& Duflo (2011) in Poor Economics: A radical rethinking of the way to fight global poverty. Banerjee \& Duflo (2011) recognize the entrepreneurial spirit that exists among those living in this zone but describe them as reluctant and risk-averse with respect to capital investments due

\footnotetext{
${ }^{33}$ The poverty trap zone is illustrated in a diagram as the S-shape of a curve whereby the $\mathrm{y}$-axis represents future income and the $\mathrm{x}$-axis represents current income. If future income is lower than current income one becomes poorer and eventually trapped in poverty (Banerjee \& Duflo, 2011, p.12).
} 
to financial constraints, adversity and uncertainty. Banerjee \& Duflo (2011) conclude that if perceived risks outweigh anticipated rewards, it will prevent the poor from pursuing capital-intensive investments. Other development economists similarly observe aversion to risk among people living at the margin, or on the edge of subsistence (Ascher, Brewer, Garry, Cheema, \& Heffron, 2016).

Understanding the economic lives of the poor is important in order to design innovations and policies that create pathways out of the poverty trap zone and achieve broader development goals such as poverty alleviation. For example, for fish processors that do not own land ${ }^{34}$ or frequently migrate in search of fish, a mobile fish smoker is perhaps more beneficial than a fixed asset. A potential pathway out of poverty in nodes dominated by women in fisheries are conditional cash transfer programs linked to social welfare programs such as basic health and family planning services, education, and small and medium-scale business training. This type of program is discussed by Ascher et al. (2016) and proposed for this node in Beran \& Crawford (2018). Beran \& Crawford (2018) discuss evidence of successful conditional and unconditional cash transfer programs benefitting women in Africa. Results from a randomized experimental design in Uganda showed that after four years of cash transfers, incomes among female beneficiaries were 84 percent greater than incomes among females in the control group, and 31 percent greater relative to incomes among males in the control group (Blattman, Fiala, \& Martinez, 2013). Conditional cash transfer programs often require families to keep children in school and provide them with basic health care. A Philippines program on conditional cash transfers

\footnotetext{
${ }^{34}$ According to Crawford et al. (2016), only 30 percent of fishing households in Ghana own non-agricultural land (i.e. property on which is house is constructed).
} 
demonstrated improved school enrollment of children aged 3-11 and reduced child stunting among the beneficiary group (Chaudhury, Friedman, \& Onishi, 2013). Ascher et al. (2016) and Banerjee \& Duflo (2011) recognize cash transfer programs are social safety nets that benefit society as a whole. The high rate of illiteracy in fishing communities and occupational environment created by smoking fish justifies implementing this type of program within this node.

Other non-adopters voice suspicion and skepticism over the innovation (Table 3.3). For example, one respondent acknowledged she "is not using the stove because it's expensive and it puts nice fish out and she will not get any price addition from customers at the traditional markets." This statement exemplifies reluctance and aversion to risk around this innovation. There is no economic incentive to use the ahotor stove according to this processor.

While for other processors it appears, there are potential economic benefits according to variables measured in this study. This study provides some evidence of economic benefits for fish processors using this innovation beginning with costsavings of fuelwood. Fish processors spend less money on fuelwood using the ahotor versus the chorkor stove (Table 3.16). This is one form of immediate compensation, but is this enough to overcome the initial cost of the investment? We propose another value proposition, that consumer-driven demand for better quality and healthier fish products will diffuse innovations. This may become more apparent and relevant as supplies from small-scale fisheries to the international market increase or through consumer awareness campaigns in the national market (e.g. where fish is processed and consumed). We suggest raising awareness of health, environmental and improved 
product attributes (e.g. color, texture and flavor of smoked fish) at the consumer node, or those at the end of the value chain to create consumer-driven demand.

In this study, those using the ahotor stove perceive it produces much better quality of smoked fish than the group using the chorkor stove. The difference is statistically significant and points to potential economic and market benefits as a result increased demand for better quality, and potentially healthier smoked fish. For example, it was noted (and observed) that the chorkor stove "makes fish dark or burns it more (e.g. smoke deposits)," while the ahotor stove "makes fish brown and appear brighter." With respect to higher demand, some respondents state fish smoked by ahotor stove "sells faster at the market than fish smoked by chorkor," while others state "all fish sells at the market and customers cannot differentiate."

Future evaluations could focus on economic and health benefits of fish smoked by improved fish processing technology. For example, a controlled experiment to determine changes in profitability using the ahotor stove or willingness to pay estimation for its products could be next steps. This would require training, coordination and communication with other nodes along the chain such as traders, transporters and consumers. Yet if other nodes perceive, or directly benefit from changes in fish processing technology, perhaps they will dictate or diffuse this innovation that upgrades this node.

\section{Conclusion}

Fish smoking technology has evolved over the years in response to changes atsea and on land. The chorkor stove addressed capacity concerns at a time when fish landings and forests were more abundant than they are today. Today, technology that 
reduces fuelwood consumption and improves safety and quality of smoked fish products is the driving force behind development of the ahotor stove.

The results presented in this paper identify factors that influence adoption of the ahotor stove in Ghana through the lens of diffusion theory. We conclude that certain technological features of the ahotor stove such as energy efficiency, smoke reduction and hands-on training plus simplicity with the ability to pay predict adoption of ahotor in Ghana. These results support recommendations made by The Guidelines (FAO, 2015) that seek ways to create value addition and reduce waste through local, energy-efficient and cost-effective innovations in small-scale fish processing. However, the cost and construction of the ahotor stove is a potential barrier to adoption. Therefore, we recommend that fuel-efficient innovations should be simple to build, easy-to-use and affordable to buy within the context of small-scale fisheries in developing countries.

In this study, we measure environmental, economic and health perceptions of new technology among fish processors in Ghana. We conclude the ahotor stove is more fuelwood-efficient than the chorkor stove. We learn that specific design features of the ahotor stove are shown to reduce PAHs based on a limited sample. These design features also prevent excessive exposure to heat and smoke, a personal health benefit to fish processors and consumers of smoked fish. The environmental paradox, however, is that complexity, or cost and construction of greener designs may outweigh the benefits of cleaner, safer smoking technology. Finally, we learn that an overwhelming majority of those using the ahotor stove state they spend less money on fuelwood using this stove versus the chorkor stove. For some along the fisheries and 
farming value chain, the trade-off is worth the investment. However, for vulnerable people working in fisheries, the struggles of daily life often stand in the way of improving it. 


\section{Appendix A}

\section{Description of stoves used to smoke fish in Ghana}

Chorkor stove (UNICEF, 1983)

The chorkor stove is built with clay mixed with sand and water and shaped by hand. Cement is sometimes also used as plaster. This stove is typically rectangular with openings or stoke holes in front. Preferably there is a dividing wall between the two chambers to support trays loaded with fish or allow use of just one chamber to smoke fish. Trays differentiate the chorkor from its predecessor, the round mud or metal barrel stove. The chorkor is designed to hold 8-10 trays. Trays are lined with wire mesh to hold fish. There is no

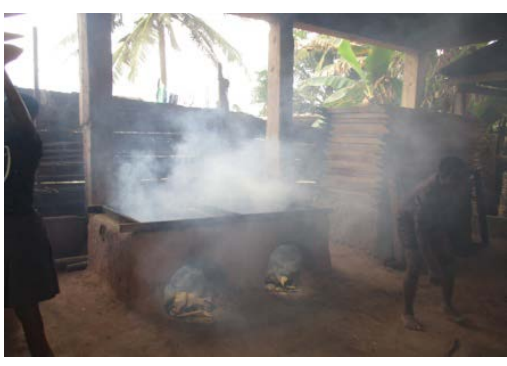

Double-unit chimney.

Morrison stove (Entee, 2015)

The morrison stove is built from clay mixed with sawdust and water. For a double unit stove, there are 2 openings for fuelwood, or combustion chambers. The two combustion chambers are separated by a wall to allow either chamber to be used in some cases. On top of each combustion chamber lies a wooden tray that is embedded in the stove frame. This frame supports trays that are used to smoke fish. The corners of the trays are designed to interlock to prevent smoke from escaping. The morrison stove is designed to hold 8-10 trays. The last tray is lined with a jute bag to filter and trap most of the smoke inside the system. Excess smoke is channeled through a small chimney made from galvanized pipe.

\section{Ahotor stove}

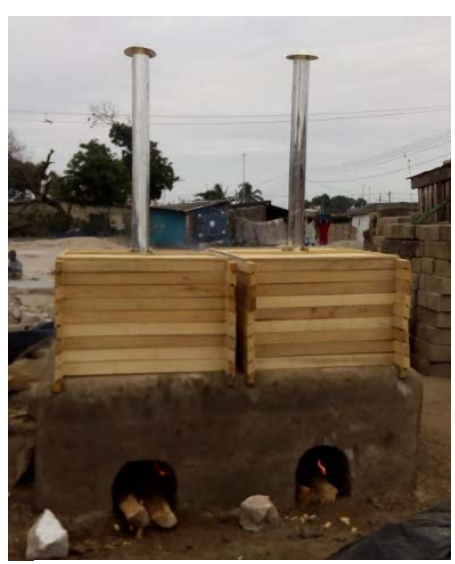

Double-unit

The ahotor, or comfort stove is a low-PAH stove model with some similar features to the morrison stove. The inner chamber of the stove is built from clay mixed with sand or ash while the outside of the stove is built from cement bricks. To reduce $\mathrm{PAH}$ levels, two prominent features were developed and installed; a twin-combustion chamber and an oil collector. The twin combustion chamber allows 1) for air to pass below the fuelwood placed on an elevated grate (allowing wood to burn more efficiently), and 2) an oil collector made of galvanized metal with holes for heat to escape. The drip collector prevents oil and other liquids from dropping into the fire. These features are intended to

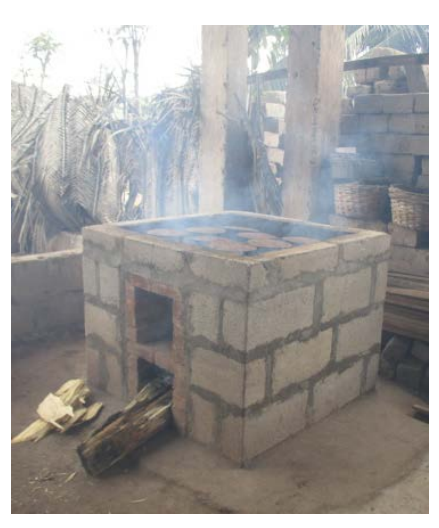
prevent the formation of high PAH levels, believed to be caused from the incomplete combustion of wood, and fat from fish dripping into open fire causing excessive exposure to heat and smoke. The single-unit stove is designed to hold 8-10 trays per unit (shown here). A hood, with a cut-out hole, is placed on top of the trays. The ahotor stove also comes as a double-unit but is shown here as a single-unit. 


\section{Appendix B}

\section{Results from the Controlled Cooking Test (CSIR et al., 2016)}

\begin{tabular}{|c|c|c|c|c|c|c|}
\hline 1. CCT results: Stove $1(\mathrm{CHORKOR})$ & units & Test 1 & Test 2 & Test 3 & Mean & St Dev \\
\hline Total weight of food cooked & $\mathrm{g}$ & 40802 & 33955 & 35330 & 36695.7 & 3622 \\
\hline Weight of char remaining & $\mathrm{g}$ & 289 & 671 & 577 & 512.3 & 199 \\
\hline Equivalent dry wood consumed & $\mathrm{g}$ & 12472.9 & 10979.7 & 10211 & 11221.3 & 1150 \\
\hline Specific fuel consumption & $\mathrm{g} / \mathrm{kg}$ & 305.7 & 323.4 & 289 & 306 & 17.2 \\
\hline Total cooking time & $\min$ & 235 & 239 & 240 & 238 & 2.6 \\
\hline $\begin{array}{l}\text { 2. CCT results: Stove } 2 \text { (AHOTOR } \\
\text { OVEN) }\end{array}$ & units & Test 1 & Test 2 & Test 3 & Mean & SD \\
\hline Total weight of food cooked & $\mathrm{g}$ & 43477 & 37098 & 36435 & 39003.3 & 3888.5 \\
\hline Weight of char remaining & $\mathrm{g}$ & 344 & 559 & 1151 & 684.7 & 417.9 \\
\hline Equivalent dry wood consumed & $\mathrm{g}$ & 9288 & 7610.2 & 7539.9 & 8146 & 989.6 \\
\hline Specific fuel consumption & $\mathrm{g} / \mathrm{kg}$ & 213.6 & 205.1 & 206.9 & 208.6 & 4.5 \\
\hline Total cooking time & $\min$ & 286 & 252 & 280 & 272.7 & 18.1 \\
\hline Comparison of Stove 1 and Stove 2 & & \multicolumn{2}{|c|}{$\%$ difference } & T-test & \multicolumn{2}{|c|}{ Sig@ $95 \%$ ? } \\
\hline Specific fuel consumption & $\mathrm{g} / \mathrm{kg}$ & \multicolumn{2}{|l|}{0.31846} & 9.5132 & \multicolumn{2}{|l|}{ YES } \\
\hline \multirow[t]{2}{*}{ Total cooking time } & $\min$ & \multicolumn{2}{|l|}{-0.1457} & -3.2741 & \multicolumn{2}{|l|}{ YES } \\
\hline & & \multicolumn{2}{|c|}{$\begin{array}{l}\text { CHORKOR } \\
\text { STOVE }\end{array}$} & \multicolumn{3}{|c|}{ AHOTOR OVEN } \\
\hline Processing rate & $\mathrm{g} / \mathrm{min}$ & \multicolumn{2}{|c|}{154.18} & \multicolumn{3}{|l|}{143.04} \\
\hline$\%$ Yield & & \multicolumn{5}{|l|}{7.22481} \\
\hline
\end{tabular}




\section{Appendix C}

Key informant questionnaire

\begin{tabular}{|l|l|}
\hline Date of Interview & \\
\hline Name of Interviewer & \\
\hline Position/Project partner & \\
\hline Region & \\
\hline Language & \\
\hline
\end{tabular}

\section{Key Informant Interview Guide}

Purpose: The goal of conducting KII with SFMP project partners is to find out what types of promotional efforts, financing mechanisms and communication channels were used to promote the Ahotor stove. The information obtained from these interviews will be used to inform Section A. of the structured questionnaire administered to fish processors in various regions to determine the impact of these efforts (promotional, financial, communication) on fish processors to adopt or not.

\section{Semi-structured Interview Questionnaire}

Promotional efforts (clarify time period, ex: 1 year):

1. Has your organization conducted any demonstration trainings of IFSS? (Y/N)

2. If yes, list all sites where a demonstration was conducted.

3. How many demonstrations were conducted at each site? (\#/site)

Financial mechanisms (discuss financing options or subsidy amount)

1. Does your organization offer any financing options for IFSS? (Y/N)

2. If yes, explain all the types of financing options available to fish processors

3. Does your organization offer a subsidy for IFSS? (Y/N)

4. If yes, what is the amount of the subsidy? (\%)

Mass communication strategies (discuss method of communication)

\begin{tabular}{|l|l|}
\hline \multicolumn{1}{|c|}{ Communication method } & Number of times used (year?) \\
\hline Radio program & \\
\hline Signage & \\
\hline Peer contact with demo user & \\
\hline Other: & \\
\hline
\end{tabular}




\section{Appendix D}

Structured questionnaire for fish processors 


\section{Ghana Fish Processor's Survey}

The purpose of this survey is to better understand how improved fish smoking stoves are being perceived by fish processors in Ghana. I will ask you questions specifically about the type of stove you are using and about the benefits and challenges of using this type of stove. This survey will take 45 minutes of your time.

You need to obtain verbal consent from the respondent before you can administer the survey. Carefully read aloud the consent form and clarify any ambiguities. Answer the following question based on the response from the respondent.

Do you, enumerator, affirm that you have read aloud the consent statement to the participant and they have consented to the enumerator through the translator?
$\bigcirc$ yes
$\bigcirc$ no

Interview number

\section{Date and time}

yyyy-mm-dd

hh:mm

Name ofcommunity

GPS

GPS coordinates can only be collected when outside.

latitude (x.y $\left.{ }^{\circ}\right)$

longitude $\left(\mathrm{x} . \mathrm{y}^{\circ}\right)$

altitude (m)

accuracy (m)

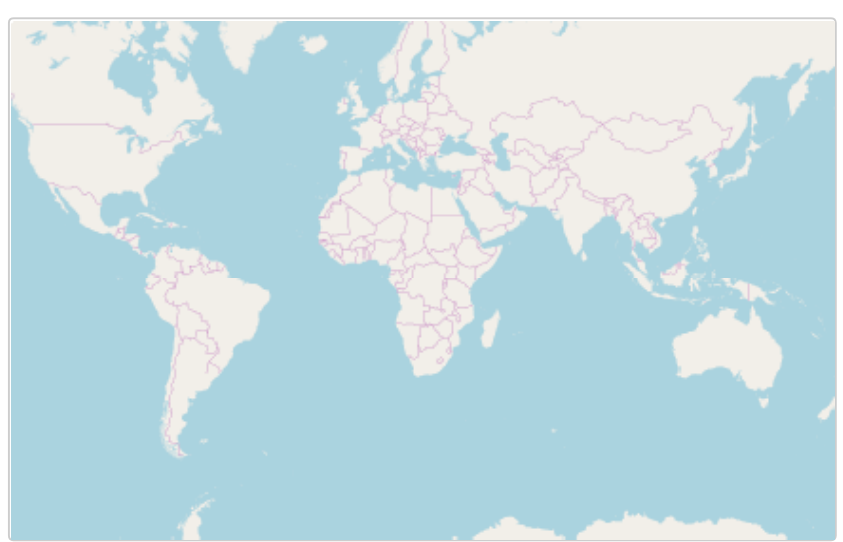


May I take your picture?

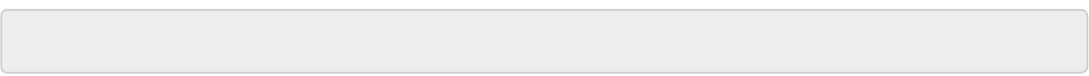
Region
$\bigcirc$ Western
Central
$\bigcirc$ Volta
Greater Accra

What language do you speak?

$\square$ Fanti
$\square$ Ewe
$\square$ Ga
$\square$ Other

Communication channels

Have you heard of Ahotor?

$\bigcirc$ yes

$\bigcirc$ no

How many months ago did you first hear about the Ahotorstove?

From whom did you first hear about Ahotor?

\begin{tabular}{|l}
$\square \quad$ Training \\
$\square \quad$ Demo \\
$\square \quad$ Media \\
$\square \quad$ Other
\end{tabular}

Specify other.

Are you using the Ahotor stove?

yes
no


Have you already signed up to finance the Ahotor?

yes

(2) no

How did you obtain your Ahotor stove?

Self finance

Demo

Morrison retrofit

Vulnerable household

Other

Specify other.

Describe how you got it in more detail

How many months ago did you get the Ahotor stove?

From which of these sources did you get information about Ahotor?

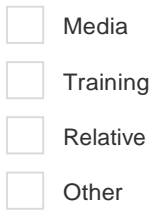

Specify other.

Which source of information influenced you (to get Ahotor) themost?

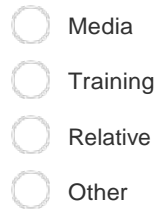

Specify other. 
Which stoves do you own now?

Chorkor

Traditional cylindrical/rectangular metal drum stove

Morrison

Morrison being converted to Ahotor

Kosmos/Frismo Oven

FTT/Thiarove stove

Other

Specify other.

Which stove(s) were you using before the Ahotor stove? (Tick all that apply)

Chorkor

Traditional cylindrical/rectangular metal drum stove

Morrison

Morrison being converted to Ahotor

Kosmos/Frismo Oven

FTT/Thiarove stove

Other

Specify other.

Which stove(s) were you using before your current stove? (Tick all that apply)

Chorkor

Traditional cylindrical/rectangular metal drum stove

Morrison

Morrison being converted to Ahotor

Kosmos/Frismo Oven

FTT/Thiarove stove

Other

Specify other. 
How many stoves do you own now?

Why did you decide to start using the Ahotor stove?

Why are you not using Ahotor stove?

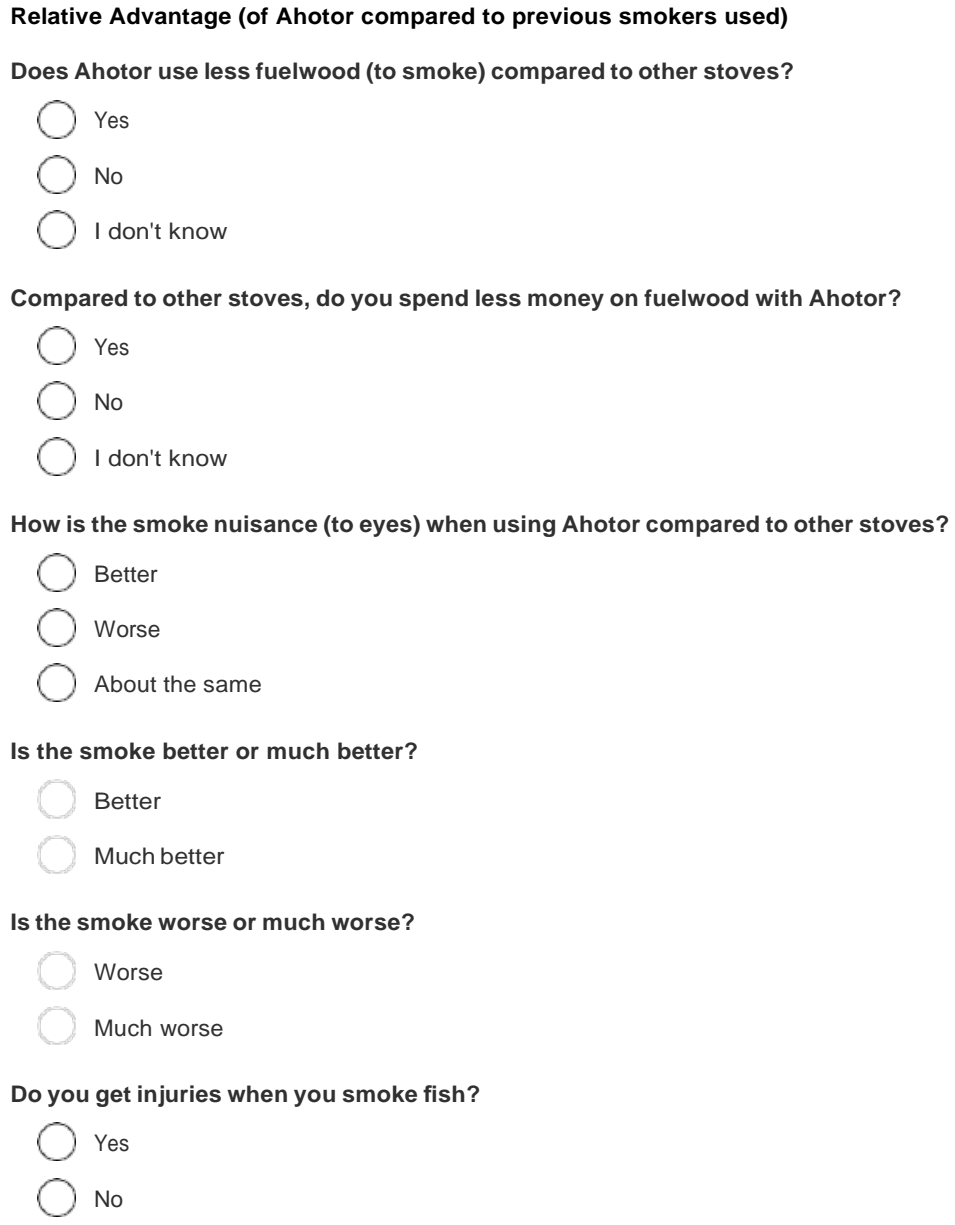

Explain the injuries 
How is the (accidental) breakage of fish during smoking with Ahotor compared to other stoves?

$\bigcirc$ Better
$\bigcirc$ Worse
$\bigcirc$ About the same

Is the breakage better or much better?

Better

Much better

Is the breakage worse or much worse?

Worse

Much worse

How is the color of fish smoked by Ahotor compared to other stoves?

$\bigcirc$ Better

Worse

About the same

Is the color of the smoked fish better or much better?

Better

Much better

Is the color of the smoked fish worse or much worse?

Worse

Much worse

Is there more demand (from the people who buy your fish) for fish smoked by Ahotor compared to fish smoked by other stoves during the bumperseason?

$\bigcirc$ Yes

$\bigcirc$ No

I don't know

If yes, explain why

Does the Ahotor stove cost less money to buy compared to other stoves you have used?
$\bigcirc$ Yes
$\bigcirc$ No
I I don't know 
Is the cost of the Ahotor stove a barrier (to buy) compared to other stoves?

$\bigcirc$ yes

○no

If yes, please explain what the barrier or difficulty of buying an Ahotor stove is?

Explain what the benefits are from investing in the Ahotor stove

Is the cost of the Ahotor worth the benefit you get compared to other stoves?
$\bigcirc$ Yes
No
I don't know

Relative Advantage (of current stove compared to previous smokers used)

Does your current stove use less fuelwood (to smoke) compared to other stoves?

$\bigcirc$ Yes

$\bigcirc$ No

I don't know

Compared to other stoves, do you spend less money on fuelwood with your current stove?
$\bigcirc$ Yes
$\bigcirc$ No
I don't know

How is the smoke nuisance (to eyes) when using your current stove compared to other stoves?

Better

$\bigcirc$ worse

About the same

Is the smoke better or much better?

Better

Much better

Is the smoke worse or much worse?

Worse

Much worse 


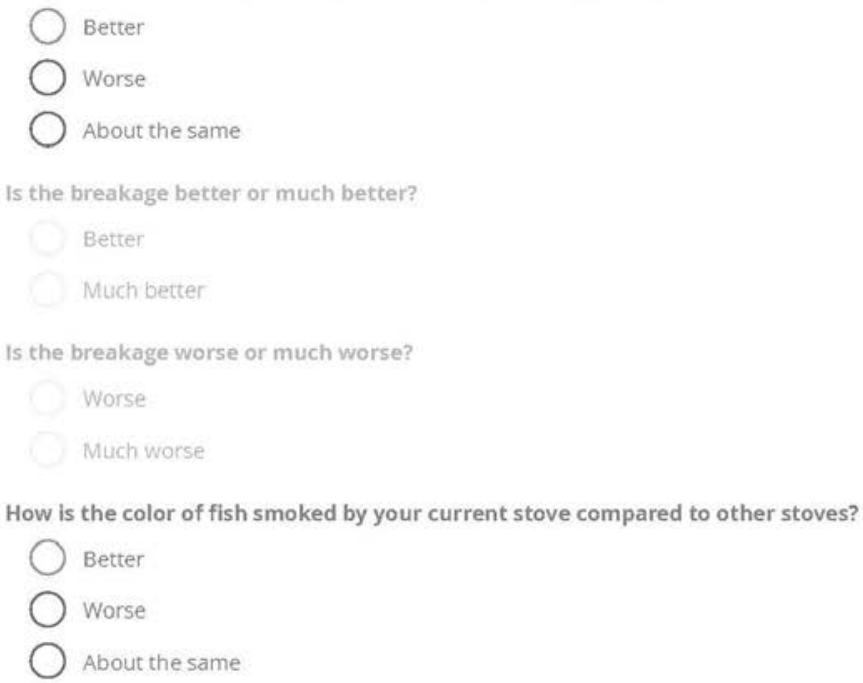

Is the color of the smoked fish better or much better?

Better

Much better

Is the color of the smoked fish worse or much worse?

Worse

Much worse

Is there more demand (from the people who buy your fish) for fish smoked by your current stove compared to fish smoked by other stoves during the bumper season?

$\bigcirc$ Yes

$\bigcirc$ No

I don't know

If yes, explain why

Does the your current stove stove cost less money to buy compared to other stoves you have used?
$\bigcirc$ Yes
$\bigcirc N_{0}$
I don't know 
Is the cost of the your current stove a barrier (to buy) compared to other stoves?

$\bigcirc$ yes

$\bigcirc$ no

If yes, please explain what the barrier or difficulty of buying your current stove is?

Explain what the benefits are from investing in your current stove

Is the cost of your current stove worth the benefit you get compared to other stoves?

$\bigcirc$ Yes

$\bigcirc$ No

I I don't know

Compatibility

Does the Ahotor stove work well for types of fish you process?

$\bigcirc$ Yes

$\bigcirc$ No

I don't know

If no, why?

Is it easy load trays?
$\bigcirc$ Yes
$\bigcirc$ No
I don't know

Do you have enough trays for the amount of fish you smoke with the Ahotor stove?
$\bigcirc$ Yes
$\bigcirc$ No
I I don't know

If no, why don't you have enough trays 
Because of this type of stove, do you need to hire extra assistance (a person to help you) to smoke?

$$
\begin{aligned}
& \bigcirc \text { Yes } \\
& \bigcirc \text { No } \\
& \text { I don't know }
\end{aligned}
$$

\section{Compatibility}

Does your current stove work well for types of fish you process?

$$
\begin{aligned}
& \bigcirc \text { Yes } \\
& \bigcirc \text { No } \\
& \text { I don't know }
\end{aligned}
$$

If no, why?

$$
\begin{aligned}
& \text { Is it easy load trays? } \\
& \text { Yes } \\
& \text { No } \\
& \text { I don't know }
\end{aligned}
$$

Do you have enough trays for the amount of fish you smoke with your current stove?

$$
\begin{aligned}
& \bigcirc \text { Yes } \\
& \text { No } \\
& \text { I don't know }
\end{aligned}
$$

If no, why don't you have enough trays

Because of this type of stove, do you need to hire extra assistance (a person to help you) to smoke?

$$
\begin{aligned}
& \bigcirc \text { Yes } \\
& \bigcirc \text { No } \\
& \text { I don't know }
\end{aligned}
$$

Complexity 
How difficult is it to learn how to use the Ahotor stove?

$\bigcirc$ Very difficult

$\bigcirc$ Difficult

Easy

$\bigcirc$ Very easy

Can you build the stove yourself?

$\bigcirc$ Yes

$\bigcirc$ No

I don't know

If no, why not?

How difficult is it to find someone (artisan) to construct/install the Ahotor stove?

$\bigcirc$ Very difficult

Difficult

Easy

$\bigcirc$ very easy

Is it easy to repair the Ahotor stove if it breaks?

$\bigcirc$ Yes

$\bigcirc$ No

I don't know

Complexity

How difficult is it to learn how to use your current stove?

$\bigcirc$ Very difficult

$\bigcirc$ Difficult

$\bigcirc$ Easy

$\bigcirc$ Very easy

Can you build the stove yourself?
$\bigcirc$ Yes
$\bigcirc$ No
I don't know 
If no, why not?

How difficult is it to find someone (artisan) to construct/install your current stove?

$\bigcirc$ Very difficult
$\bigcirc$ Difficult
$\bigcirc$ Easy
$\bigcirc$ Very easy

Is it easy to repair your current stove if it breaks?

$\bigcirc$ Yes

$\bigcirc$ No

I Idon't know

Trialability

Did you receive training on how to use the Ahotor stove before getting it?

$\bigcirc$ yes

$\bigcirc$ no

Did you experiment with the Ahotor stove enough times until you were satisfied before deciding to get it?

yes

(3) no

Trialability

Did you receive training on how to use your current stove before getting it?

yes

@ no

Did you experiment with your current stove enough times until you were satisfied before deciding to get it?

(a) yes

(2) no

Observability

Is your stove located in an area where other smokers can easily see it?

$\bigcirc$ Yes

$\bigcirc$ No

I don't know 
Do other fish processors who do not have an Ahotor ask you about your stove?
$\bigcirc$ Yes
$\bigcirc$ No
I don't know

Is it noticeable to other people that fish smoked by Ahotor is different?

$\bigcirc$ Yes

$\bigcirc$ No

I don't know

If yes, how do other people describe the difference between fish smoked by Ahotor and fish smoked by other stoves?

\section{Observability}

Is your stove located in an area where other smokers can easily see it?

$\bigcirc$ Yes

$\bigcirc$ No

I I don't know

Do other fish processors who do not have your stove ask you about your stove?

$\bigcirc$ Yes

$\bigcirc$ No

I don't know

Is it noticeable to other people that fish smoked by your current stove is different?

$\bigcirc$ Yes

$\bigcirc$ No

I don't know

If yes, how do other people describe the difference between fish smoked by your current stove and fish smoked by other stoves?

Socio-demographic information

What is your age? 
How many years have you been smoking fish?

How do you know how much money you are making?

Do you leave your community to sell your fish?
$\bigcirc$ Often
$\bigcirc$ Occasionally
Rarely
$\bigcirc$ Never

At approx. how many different markets do you sell yourfish?

List the most important market.

Why is this the most important?

What much of your household income is from fish smoking?
Less than $25 \%$
(25-50\%
(50-75\%
(75-100\%

Which of the following do you have in your household?

$\square$ Radio
$\square$ Tape player
$\square$ TV
$\square$ Sewing machine
$\square$ Refrigerator


Type of roof

$\bigcirc$ Asbestos or slate
Corrugated metal sheets
Other

Type of floor

$\bigcirc$ Cement or concrete

$\bigcirc$ Earth, mud, mud bricks

Other

Do you have water supply in house?

$\bigcirc$ yes

○no

Do you have electricity supply in the house?

$\bigcirc$ yes

$\bigcirc$ no

Dwelling toilet type

$\square$ KVIP

$\square$ Public toilet

$\square$ No toilet facility

Other

Perceived economic, health and environmental benefits

Does fish smoked by Ahotor sell faster (to buyer/market) than fish smoked by other stoves?

$\bigcirc$ Yes

$\bigcirc$ No

I don't know

How is the quality of fish smoked using Ahotor compared to previous stoves?

$\bigcirc$ Better

Worse

About the same

Is the quality better or much better?

Better

Much better 
Is the quality worse of muchworse?

Worse

Much worse

Do you believe the Ahotor stove will pay for itself in

Less than 1 year

○ year

More than 1 year

I I don't know

With Ahotor, do you experience less asthma and coughing?
$\bigcirc$ Yes
$\bigcirc$ No
I don't know

Are you concerned about scarcity of fuelwood?

$\bigcirc$ Yes

$\bigcirc$ No

I don't know

Is scarcity of fuelwood a reason why you use Ahotor?

$\bigcirc$ yes

$\bigcirc$ no

Ahotor helps protect forest (fuelwood) habitat

Strongly disagree

Disagree

A Agree

Strongly agree

Perceived economic, health and environmental benefits

Does fish smoked by your current stove sell faster (to buyer/market) than fish smoked by other stoves? $\bigcirc$ Yes

$\bigcirc$ No

I don't know 
How is the quality of fish smoked using your current stove compared to previous stoves?

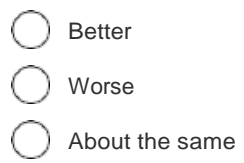

Is the quality better or much better?
Better
Much better

Is the quality worse of muchworse?

Worse

Much worse

With your current stove, do you experience less asthma and coughing compared to previous stoves?

$\bigcirc$ Yes

$\bigcirc$ No

I don't know

Are you concerned about scarcity of fuelwood?
$\bigcirc$ Yes
No
I don't know

Is scarcity of fuelwood a reason why you use your current stove?

$\bigcirc$ yes

$\bigcirc$ no

Your current stove helps protect forest (fuelwood) habitat
Strongly disagree
$\bigcirc$ Disagree
Agree
Strongly agree

\section{Perceived environmental benefits of fuelwood}

Suppose the bottom square represents the worst possible overall condition of availability of fuelwood and the top represents the best. For example, the worst possible availability of fuelwood is when you have to travel further to get wood or pay more for fuelwood and sometimes you do not smoke fish because fuelwood is scarce or expensive. The best availability of fuelwood is when you can easily get fuelwood and you do not need to pay more for it because it is abundant, there is plenty of fuelwood nearby. 
Where on the ladder is the availability of fuelwood this year?

$\bigcup^{10}$ (Best)
$\bigcirc^{9}$
7
${ }^{6}$
5
4
3
1

Where was it 5 years ago?

$\bigcirc 10$ (Best)

○ 9

( 8

$\bigcirc 7$

( 6

$\bigcirc 5$

( 4

$\bigcirc 3$

$\bigcirc 2$

$\bigcirc 1$ (Worst)

Where will the availability of fuelwood be 5 years from now?

$\bigcirc 10$ (Best)

○ 9

$\bigcirc 8$

○ 7

( 6

$\bigcirc 5$

( 4

$\bigcirc 3$

(3) 2

( 1 (Worst) 


\section{Perceived environmental benefits of fishing}

Suppose the bottom square represents the worst possible overall economic fishing conditions and the top represents the best. For example, the worst possible fishing conditions is when when one goes out to sea and catches no fish at all and sometimes do not even go to sea because you think there will be no fish to catch. The best possible fishing conditions is ifyou go to sea and fill your whole boat with fish in a short period of time and there is plenty of fish to catch.

Where on the ladder are fishing conditions this year?

$\bigcirc 10$ (Best)

( 9

○ 8

@ 7

(C) 6

(C) 5

( 4

$\bigcirc 3$

() 2

○ (Worst)

Where were they 5 years ago?

$\bigcup^{10}$ (Best)
$\bigcirc^{8}$
7
$\bigcirc^{6}$
5
3
3
1 (Worst)


Where will fishing be 5 years from now?

$\bigcup^{10}$ (Best)
${ }^{8}$
${ }^{7}$
6
$\bigcirc^{5}$
3
2

Women's participation in fisheries management of sardinella

Do you belong to any organizations that discuss rules and laws about fishing?
$\bigcirc$ yes
$\bigcirc$ no

Why not?

Which organizations?

Select your level of particpation

Very active

Somewhat active

Rarely active

Are you comfortable speaking up at these meetings about problems in the fishery that affect you?

Yes

No

I don't know

If no, why not? 
Do you feel you have influence (over friends and family) about their fishing practices?
Yes
No
I I don't know

Do you own any fishing boats?
$\bigcirc$ yes
$\bigcirc$ no

Do you finance any fishing trips?

$\bigcirc$ yes

( no 


\section{Appendix E}

Scale construction to measure innovation attributes

Definition: Relative advantage is the degree to which an innovation is perceived as being better than the one before it. In this study, we ask respondents about the degree to which their current stove is better than their previous stove.

Measurement: Nine sub-variables, or indicators, measure relative advantage. The subvariables $^{35}$ are scaled questions.

Sub-variables

XLWG $=$ do you use less fuelwood?

[-1 = no, 0 = I don’t know, 1 = yes $]$

XSPG $=$ do you spend less money on fuelwood?

[-1 = no, 0 = I don't know, 1 = yes $]$

$\mathrm{EG}=$ how is the smoke nuisance to your eyes?

[ $1=$ much better, $0.5=$ better, $0=$ same, $-0.5=$ worse, $-1=$ much worse $]$

$\mathrm{BG}=$ How is the breakage of fish?

[ $1=$ much better, $0.5=$ better, $0=$ same, $-0.5=$ worse, $-1=$ much worse $]$

CT $=$ How is the color of fish?

[ $1=$ much better, $0.5=$ better, $0=$ same, $-0.5=$ worse, $-1=$ much worse $]$

$\mathrm{XHDG}=$ Is demand higher?

[-1 = no, 0 = I don't know, 1 = yes $]$

$\mathrm{XCOSG}=$ Does the stove cost less than the previous stove?

[-1 = no, 0 = I don't know, 1 = yes $]$

$\mathrm{XBARG}^{36}=$ Is the cost of the stove a barrier to buy?

[1= yes, $-1=$ no]

$\mathrm{XCOBEG}=$ Is the cost worth the benefit?

[-1 = no, 0 = I don’t know, 1 = yes $]$

Ahotor treatment group: $n=48$

Chorkor treatment group: $n=63$

${ }^{35}$ Sub-variables are transformed based on stove treatment group. For example, XLWG is a transformed variable from XLESSWOOD + XCLESSWOOD. XLESSWOOD is a scaled question about use of fuelwood directed at the ahotor treatment group, whereas XCLESSWOOD is the same question but directed at the chorkor treatment group.

${ }^{36}$ Score reversed to ensure directional continuity with other scales. 
Definition: Compatibility is the extent to which an innovation is consistent with existing values, past experiences and needs of potential adopters. In this study, we ask respondents if their current stove is consistent with their needs of a stove based on the evolution of smoking technology, or past stoves.

Measurement: Four sub-variables, or indicators, measure compatibility. The subvariables ${ }^{37}$ are scaled questions.

Sub-variables

XWORG= does the stove work well for the types of fish you process?

[-1 = no, 0 = I don't know, 1 = yes $]$

XEZLG $=$ is it easy to load trays?

[-1 = no, 0 = I don't know, 1 = yes $]$

XSUFG = do you have enough trays for the amount of fish you smoke?

[-1 = no, 0 = I don't know, 1 = yes $]$

$\mathrm{EXTG}^{38}=$ do you need to hire extra assistance to help you smoke?

[-1 = no, 0 = I don't know, 1 = yes $]$

Ahotor treatment group: $n=48$

Chorkor treatment group: $n=63$

${ }^{37}$ Sub-variables are transformed based on stove treatment group. For example, XWORG is a transformed variable from XWORKWELL + XCWORKWELL. XWORKWELL is a scaled question about compatibility of stove with types of fish processed directed at the ahotor treatment group, whereas XCWORKWELL is the same question but directed at the chorkor treatment group.

${ }^{38}$ Score reversed to ensure directional continuity with other scales. 
Definition: Complexity is the extent to which an innovation is perceived easy or difficult to use. In this study, we ask respondents about the degree to which their current stove is easier or more difficult to use, build and repair.

Measurement: Four sub-variables, or indicators, measure complexity. The subvariables ${ }^{39}$ are scaled questions.

Sub-variables

DIFG $=$ how difficult is it to use?

[1 = very easy, 0.5 = easy, -0.5 = difficult, -1 = very difficult $]$

XBLDG = can you build it?

[-1= no, 0 = I don't know, $1=$ yes $]$

EZFG $=$ how difficult is it to find someone to build it?

[1 = very easy, 0.5 = easy, $-0.5=$ difficult, -1 = very difficult $]$

XEZRG $=$ is it easy to repair?

$[-1=$ no, 0 = I don't know, $1=$ yes $]$

Ahotor treatment group: $n=48$

Chorkor treatment group: $n=63$

${ }^{39}$ Sub-variables are transformed based on stove treatment group. For example, DIFG is a transformed variable from DIFFICULT + CDIFFICULT. DIFFICULT is a scaled question about ease of use (of stove) directed at the ahotor treatment group, whereas CDIFFICULT is the same question but directed at the chorkor treatment group. 
Definition: Trialability is the extent to which an innovation may be experimented with or tested. In this study, we ask respondents about the degree to which they were trained on their current stove compared to their previous stove and level of satisfaction with the training(s).

Measurement: Two sub-variables, or indicators, measure trialability. The subvariables ${ }^{40}$ are scaled questions.

Sub-variables

XTRIG $=$ Did you get trained on it?

[0 = no, $1=$ yes $]$

XTXPG = did you get enough training until you were satisfied before using it?

$[0=$ no, $1=$ yes $]$

Ahotor treatment group: $n=48$

Chorkor treatment group: $n=63$

${ }^{40}$ Sub-variables are transformed based on stove treatment group. For example, XTRIG is a transformed variable from XTRITRAIN + XCTRITRAIN. XTRITRAIN is a scaled question about training (of stove) directed at the ahotor treatment group, whereas XCTRITRAIN is the same question but directed at the chorkor treatment group. 
Definition: Observability is the extent to which results of an innovation are visible to others. In this study, we ask respondents if the stove they are being asked about is visible to others, or if others express interest in the stove, or if fish smoked by the stove looks different than fish smoked by a previous stove.

Measurement: Three sub-variables, or indicators, measure observability. The subvariables ${ }^{41}$ are scaled questions.

Sub-variables

XECG $=$ is it (stove) visible to others?

[-1 = no, 0 = I don't know, 1 = yes $]$

XASKG $=$ do other fish processors ask you about your stove?

[-1 = no, 0 = I don't know, 1 = yes $]$

XVISG = is it noticeable to others that fish smoked by your current stove looks different than fish smoked by your previous stove?

[-1 = no, 0 = I don't know, 1 = yes $]$

Ahotor treatment group: $n=48$

Chorkor treatment group: $n=63$

${ }^{41}$ Sub-variables are transformed based on stove treatment group. For example, XECG is a transformed variable from XEASYSEE + XCEASYSEE. XEASYSEE is a scaled question about visibility of the stove directed at the ahotor treatment group, whereas XCEASYSEE is the same question but directed at the chorkor treatment group. 
Appendix F

Self-anchoring ladder (Cantril, 1963)

\begin{tabular}{|c|}
\hline 10 (Best) \\
\hline 9 \\
\hline 8 \\
\hline 7 \\
\hline 6 \\
\hline 5 \\
\hline 4 \\
\hline
\end{tabular}




\section{References}

Akande, G., \& Diei-Ouadi, Y. (2010). Post-harvest Losses in Small-scale Fisheries: Case Studies in Five sub-Saharan African Countries. FAO Fisheries and Aquaculture Technical Paper, (550). 77p.

Akpambang, V., Purcaro, G., Lajide, L., Amoo, I., Conte, L., \& Moret, S. (2009). Determination of Polycyclic Aromatic Hydrocarbons (PAHs) in Commonly Consumed Nigerian Smoked/Grilled Fish and Meat. Food Additives and Contaminants, 26(7), 1096-1103.

Ascher, W., Brewer, G. D., Cheema, G. S., \& Heffron, J. M. (2016). Evolution of Economic Development Theories and Doctrines Since World War II. The Evolution of Development Thinking. Springer. 15-39pp.

Avega, B., \& Tibu, G. (2017). Performance evaluation survey (Ahotor oven). The USAID/Ghana Sustainable Fisheries Management Project (SFMP). Narragansett, RI: Coastal Resources Center, Graduate School of Oceanography, University of Rhode Island and Netherlands Development Organisation.GH2014_ACT099_SNV.33p.

Ba, A., Schmidt, J., Dème, M., Lancker, K., Chaboud, C., Cury, P., . . Brehmer, P. (2017). Profitability and Economic Drivers of Small Pelagic Fisheries in West Africa: A Twenty-year Perspective. Marine Policy, 76, 152-158. doi:https://doi.org/10.1016/j.marpol.2016.11.008

Bailis, R. (2004). Controlled Cooking Test. Version 2.0. Shell Foundation (Household Energy and Health Programme). https://cleancookstoves.org/binarydata/DOCUMENT/file/000/000/80-1.pdf

Banerjee, A. V., Banerjee, A., \& Duflo, E. (2011). Poor Economics: A Radical Rethinking of the Way to Fight Global Poverty. Public Affairs. New York.

Beran, K., Crawford, B. (2018). Assessment of Ahotor Stove Grants on Households Vulnerable to Child Labor and Trafficking. The USAID/Ghana Sustainable Fisheries Management Project (SFMP). Narragansett, RI: Coastal Resources Center, Graduate School of Oceanography, University of Rhode Island and CEWEFIA and DAA. 30 pp.

Blattman, C., Fiala, N., \& Martinez, S. (2013). Generating Skilled Self-Employment in Developing Countries: Experimental Evidence from Uganda. The Quarterly Journal of Economics, 129(2), 697-752.

Cantril, H., \& Livingston, W. K. (1963). The Concept of Transaction in Psychology and Neurology. Journal of Individual Psychology, 19(1), 3. 
Cattell, R. B. (1966). The Scree Test for the Number of Factors. Multivariate Behavioral Research, 1(2), 245-276.

Chaudhury, N., Friedman, J., \& Onishi, J. (2013). Philippines Conditional Cash Transfer Program Impact Evaluation 2012. Manila: World Bank Report, (75533$\mathrm{PH})$.

Cinner, J., Daw, T., \& McClanahan, T. (2009). Socioeconomic Factors that Affect Artisanal Fishers’ Readiness to Exit a Declining Fishery. Conservation Biology, 23(1), 124-130.

Codex Alimentarius Commission. (2009). Code of Practice for the Reduction of Contamination of Food with Polycyclic Aromatic Hydrocarbons (PAH) from Smoking and Direct Drying Processes. Cac/rcp, 68.

Cohen, J. (1988). Statistical Power Analysis for the Behavioral Sciences. 2nd.

Crawford, B., Gonzales, L., Amin, D., Nyari-Hardi, B., \& Sarpong, Y. (2016). Report on the Baseline Survey of Small Pelagic Fishing Households Along the Ghana Coast. The USAID/Ghana Sustainable Fisheries Management Project (SFMP) Narragansett, RI: Coastal Resources Center, Graduate School of Oceanography, University of Rhode Island.GH2014_PGM187_CRC. 122pp.

Dentoni, D., \& English, F. (2012). Dealing with Cultural Differences in Public-Private R\&D projects: The Experience of the Australian Seafood Sector. International Food and Agribusiness Management Review, 15(A), 127-132.

Dewees, C., \& Hawkes, G. (1988). Technical Innovation in the Pacific Coast Trawl Fishery: The Effects of Fishermen's Characteristics and Perceptions on Adoption Behavior. Human Organization, 47(3), 224-234.

European Food Safety Authority. (2008). Polycyclic Aromatic Hydrocarbons in Food. Scientific Opinion of the Panel on Contaminants in the Food Chain. European Food Safety Authority Journal 724, 114p.

Entee, S. (2015). Post-harvest Processing Value Chain Literature Review Report. The USAID/Ghana Sustainable Fisheries Management Project (SFMP). Narragansett, RI: Coastal Resources Center, Graduate School of Oceanography, University of Rhode Island and Netherlands Development Organization.GH2014_ACT022_SNV.36pp.

Food and Agriculture Organization of the United Nations. (February, 2016). Fishery and Aquaculture Country Profiles. The Republic of Ghana. Retrieved August 12, 2018 from http://www.fao.org/fishery/facp/GHA/en. 
Food and Agriculture Organization of the United Nations. (2015). Voluntary guidelines for securing sustainable small-scale fisheries in the context of food security and poverty eradication. Food and Agriculture Organization of the United Nations. Rome.

Gordon, A., Pulis, A., \& Owusu-Adjei, E. (2011). Smoked Marine Fish from Western Region, Ghana: A Value Chain Assessment. World Fish Center. 41pp.

Hall, G. M. (2011). Fish Processing: Sustainability and New Opportunities. John Wiley \& Sons. Oxford, UK.

Harlow, L. (2014). The Essence of Multivariate Thinking: Basic Themes and Methods. Routledge. New York.

Institute for Industrial Research [CSIR], Ghana Standards Authority [GSA], Kwarteng, E. (2016). Testing of low PAH Improved Fish Smoking Stove (Ahotor oven). The USAID/Ghana Sustainable Fisheries Management Project (SFMP), Narragansett, RI: Coastal Resources Center, Graduate School of Oceanography, University of Rhode Island. GH2014_ACT067_SNV. 19p.

James, J. (2013). The Diffusion of IT in the Historical Context of Innovations from Developed Countries. Social Indicators Research. 111(1), 175-184.

Karl, H., \& Leinemann, M. (1996). Determination of Polycyclic Aromatic Hydrocarbons in Smoked Fishery Products from Different Smoking Kilns. Zeitschrift Für Lebensmittel-Untersuchung Und Forschung, 202(6), 458464.

Kwarteng, E. (2015). Fuelwood Value Chain Analysis Literature Review Report. The USAID/Ghana Sustainable Fisheries Management Project (SFMP). Narragansett, RI: Coastal Resources Center, Graduate School of Oceanography, University of Rhode Island and SNV Netherlands Development Organization.GH2014_SCI010_SNV.91pp.

Kwarteng, E., Nsiah, A., \& Aziebor, E. (2016). Energy Expenditure and Comparative Economics of Fish Processing Techniques Report. The USAID/Ghana Sustainable Fisheries Management Project (SFMP). Narragansett, RI: Coastal Resources Center, Graduate School of Oceanography, University of Rhode Island.GH 2014_ACT076_SNV. 34pp.

Lao, J., Xie, S., Wu, C., Bao, L., Tao, S., \& Zeng, E. Y. (2018). Importance of Dermal Absorption of Polycyclic Aromatic Hydrocarbons Derived from Barbecue Fumes. Environmental Science \& Technology, 52(15), 8330-8338.

Lazar, N., Asare, C., Nortey, D., Kankam, S., \& Agbogah, K. (2016). The Small Pelagic Fisheries Profile: Analysis of Regional Results. USAID/Sustainable 
Fisheries Management Project (SFMP). Narragansett, RI: Coastal Resources Center, Graduate School of Oceanography, University of Rhode Island and Hen Mpoano.GH2014_ACT001_CRC.39pp.

Lowry, K. (1985). Assessing the Implementation of Federal Coastal Policy. Journal of the American Planning Association, 51(3), 288-298.

Madanda, A. (2003). Commercialization and Gender Roles among Lake Victoria Shore Fishing Communities in Uganda. Addis Abada: OSSREA. Research report. 61pp.

Marchi, V. D., Maria, E. D., \& Micelli, S. (2013). Environmental Strategies, Upgrading and Competitive Advantage in Global Value Chains. Business Strategy and the Environment, 22(1), 62-72.

Moore, G. C., \& Benbasat, I. (1991). Development of an Instrument to Measure the Perceptions of Adopting an Information Technology Innovation. Information Systems Research, 2(3), 192-222.

Mutimukuru-Maravanyika, T., Mills, D. J., Asare, C., \& Asiedu, G. A. (2016). Enhancing Women's Participation in Decision-Making in Artisanal Fisheries in the Anlo Beach Fishing Community, Ghana. Water Resources and Rural Development. https://doi.org/10.1016/j.wrr.2016.04.001.

Odjidja, E., Yeboah, D., Abgekpornu, H., Manu, S. and K. Beran. (2016). Morrison Stove Independent Evaluation Report. The USAID/Ghana Sustainable Fisheries Management Project (SFMP). Fisheries Commission, Ministry of Fisheries and Aquaculture Development, and Coastal Resources Center, Graduate School of Oceanography, University of Rhode Island. Narragansett, RI. 55p.

Overa, R. (1993). Wives and Traders: Women's careers in Ghanaian Canoe Fisheries. Maritime Anthropological Studies, 6(1-2), 110-135.

Pankratz, M., Hallfors, D., \& Cho, H. (2002). Measuring Perceptions of Innovation Adoption: The Diffusion of a Federal Drug Prevention Policy. Health Education Research, 17(3), 315-326.

Plahar, W. A., Nerquaye-Tetteh, G. A., \& Annan, N. T. (1999). Development of an Integrated Quality Assurance System for the Traditional Sardinella sp. and Anchovy Fish Smoking Industry in Ghana. Food Control, 10(1), 15-25.

Poggie Jr, J. (1972). Toward Quality Control in Key Informant Data. Human Organization, 31(1), 23-30.

Pollnac, R. B., \& Crawford, B. R. (2000). Assessing Behavioral Aspects of Coastal Resource Use. Proyek Pesisir Publications Special Report. Coastal Resources 
Center Coastal Management Report \#2226. Coastal Resources Center, University of Rhode Island, Narragansett, Rhode Island. 139pp.

Pollnac, R. B., \& Poggie, J., John J. (2006). Job Satisfaction in the Fishery in Two Southeast Alaskan Towns. Human Organization, 65(3), 329-339.

Quinn, N. (1978). Do Mfantse Fish Sellers Estimate Probabilities in their Heads? American Ethnologist, 5(2), 206-226.

Quisumbing, A. R., \& Pandolfelli, L. (2010). Promising Approaches to Address the Needs of Poor Female Farmers: Resources, Constraints, and Interventions. World Development, 38(4), 581-592. doi:https://doi.org/10.1016/j.worlddev.2009.10.006.

Richardson, J. T. (2011). Eta Squared and Partial Eta Squared as Measures of Effect Size in Educational Research. Educational Research Review, 6(2), 135-147.

Robson, C. (2011). Real World Research: A Resource for Users of Social Research Methods in Applied Settings. Third edition.

Rogers, E, M. (1995). Diffusion of Innovations. Fourth edition. The Free Press. New York.

Steckler, A., Goodman, R. M., McLeroy, K. R., Davis, S., \& Koch, G. (1992). Measuring the Diffusion of Innovative Health Promotion Programs. American Journal of Health Promotion, 6(3), 214-224.

Stephenson, G. O. (1980). " Pushing for the highline": The Diffusion of Innovations in the Oregon Otter Trawl Fishery. Master of Arts Thesis. Retrieved August 12, 2018 from https://ir.library.oreganstate.edu/downloads/7h149t88k.

Tango-Lowy, T., \& Robertson, R. A. (2002). Predisposition Toward Adoption of Open Ocean Aquaculture by Northern New England's Inshore, Commercial Fishermen. Human Organization, 61(3), 240-251.

Tornatzky, L. G., \& Klein, K. J. (1982). Innovation Characteristics and Innovation Adoption-Implementation: A Meta-Analysis of Findings. IEEE Transactions on Engineering Management, (1), 28-45.

United Nations. (2016). Sustainable Development Goals Report. 2016. United Nations. New York.

Walker, B. L. E. (2001). Sisterhood and Seine-Nets: Engendering Development and Conservation in Ghana's Marine Fishery. The Professional Geographer, 53(2), 160-177. 
Weeratunge, N., Snyder, K. A., \& Sze, C. P. (2010). Gleaner, Fisher, Trader, Processor: Understanding Gendered Employment in Fisheries and Aquaculture. Fish and Fisheries, 11(4), 405-420.

World Health Organization. (2018). International Food Standards (FAO/WHO Codex Alimentarius). Retrieved August 12, 2018 http://www.who.int/foodsafety/areas_work/food-standard/en/. 


\title{
Chapter 4
}

\section{IMPLEMENTING VALUE CHAIN IMPROVEMENTS IN SMALL-SCALE FISHERIES: CASE STUDIES FROM WEST AFRICA}

\author{
by
}

Kristine Beran $^{1}$

To be submitted to Global Food Security

\footnotetext{
${ }^{1} \mathrm{PhD}$ Candidate, Department of Marine Affairs, University of Rhode Island, RI, 02881, USA, Email: Kristine_beran@uri.edu.
} 


\section{Introduction}

Seafood is one of the most traded food commodities worldwide by value. It is estimated half of the world's fish landings come from small-scale fisheries in developing countries. Many fisheries, however, fail to maximize value of seafood products due to post-harvest loss, production, distribution and marketing challenges. This research investigates ways post-harvest innovations address some of these challenges, whom they benefit, and factors that influence adoption through two case studies in West Africa. The overarching questions summarized in this chapter are:

1. What is the theory behind reducing post-harvest loss and in that sense upgrading small-scale fisheries in West Africa?

2. What are some socio-economic outcomes of value chain upgrades, who benefits and how do these outcomes align with or contradict theory?

3. What factors influence adoption among its users?

The value chain approach (VCA) and diffusion of innovation theory is used to address these questions. The objective of this dissertation is to design and implement a framework to upgrade nodes along the chain by diffusing an innovation in small-scale fisheries in developing countries. The value chain upgrading framework is introduced in chapter 1 (Figure 1.1). It is informed by two case studies presented in chapter 2 and 3. Application of this framework is summarized by node, innovation undertaken and results obtained, fulfilling this objective. The different characteristics of each case study suggest wider application of the framework within this sector. This chapter discusses results and presents practical implications within the broader context of 
small-scale fisheries. Theoretical implications based on outcomes of this research are also discussed. Future research is suggested where applicable in certain areas.

\section{Summary of Results by Node}

Fisher node

A value chain analysis conducted for Gambian sole identified inadequate temperature-controlled processes in the supply chain (Fafanding, Tobey, \& Drammeh, 2010). Results from this analysis created opportunities for upgrading. Results specifically recommended improvements to packaging materials, storage and transportation of sole from the fishing vessel to the processing plant in Banjul, the capital (Fafanding et al., 2010). The World Bank’s Fishery Performance Indicators is another tool used to assess economic performance of a fishery, among other biological and non-biological dimensions (Anderson et al., 2015). This tool was used to qualitatively assess shrink or loss within the sole fishery post-harvest sector. Based on this assessment in 2012, loss of sole was reported between 30-35 percent in value in local currency (C. Anderson, personal communication, November 11, 2016).

In 2015, a relatively simple innovation, or ice and ice coolers on-board artisanal fishing vessels was implemented within this node. The purpose behind this innovation was to improve post-harvest quality of sole for export thereby reducing quality-related loss (Beran, Pollnac, \& Torell, under review). Primary data were collected to measure differences with respect to post-harvest quality loss of sole between fishers and buyers using ice or not. Results obtained indicate fishers using ice lost 14 percent less sole by weight $(\mathrm{kg})$ than fishers not using ice, however, the cost of ice exceeded the difference in revenue earned on average. Fisher's use of ice had a 
statistically significant positive impact on the buyer's loss of sole which was less than one percent by weight. Buyers are provisioned with ice from the processing plant in return for delivering fish, therefore, they do not incur the additional cost of ice and as a result captured more economic benefits in this study.

This study also examined cross-cutting themes discussed in the author's framework (Figure 1.1) such as gender, food security and biodiversity. For example, the innovation only targeted fishers and buyers of export-oriented sole, nodes dominated by men. No prior assessment was conducted to determine how this innovation might impact the domestic market for sole, a sector dominated by women. However, field experience and a value chain analysis indicate sole is typically not processed using traditional methods (e.g. salting, drying), nor consumed fresh in large amounts in The Gambia (Fafanding et al., 2010). This assumption was confirmed through a survey administered to processors supplying the domestic market with fish. Results from this survey suggest increasing the proportion of fish for export does not impact local trade and consumption of sole unless sole replace other species, for example if fishers target sole and catch less catfish which is purchased by local women processors. Sole was not ranked as economically important species for the domestic market and it was not a preferred species for household consumption.

Overcapacity and overfishing may occur as a result of post-harvest innovations that increase revenue in the absence of fisheries management measures. Tangible benefits, however, may serve as incentives to improve fisheries management (Uchida, 2017). The concept of quick, tangible benefits that garner support for collective fisheries management in the long-term is discussed by Uchida (2017). The value chain 
upgrading framework (Figure 1.1) recommends implementing innovations that align with sustainable harvesting practices in fisheries engaged in some type of fishery improvement project. The Gambian sole fishery is currently in an accredited Fishery Improvement Project (Fisheryprogress.org, URL: https://fisheryprogress.org/fipprofile/gambia-sole-bottom-set-gillnet). A Fishery Improvement Project brings together multiple fishery stakeholders such as sellers and buyers to collectively improve the management, and thus sustainability of a fishery.

\section{Processor node}

Like in The Gambia, a value chain analysis was conducted by Nunoo, Asiedu, Belhabib, Lam, Sumaila, and Pauly (2015) for small pelagic species (e.g. sardinella) and by Kwarteng (2015) for fuelwood in Ghana. Based on these assessments, recommendations include, 1) better hygiene and handling practices for fish, improved packaging and labeling of smoked fish, and 2) establishing woodlots to supply fuelwood for fish processing (Nunoo et al., 2015; Kwarteng, 2015). Post-harvest loss of smoked fish in Ghana-caused by burning, infestation and insects-is reported between 3 and 17 percent of weight (Akande \& Diei-Ouadi, 2010). Akande and DieiOuadi (2010) estimate this loss has a macroeconomic impact valued at 60 million USD. Further, net loss of forests in Africa is among the highest worldwide (FAOb, 2015).

A slightly more complex innovation is introduced within this node to address both types of loss. The innovation is a fuel-efficient fish smoking stove known as the ahotor. This stove is designed to produce healthier, better quality smoked fish for the Ghanaian market. This study measured factors that influence adoption of the ahotor 
stove according to diffusion theory using principal component analysis. Fifty-one percent of the variance in the data is explained by three components, the first component is named technology. Results obtained indicate technology characterized by energy efficiency, smoke reduction and hands-on training plus simplicity and the ability to pay predict adoption of the ahotor stove in Ghana. Factors that could hinder adoption of the ahotor stove relate to complexity, the only perceived attribute that is negatively correlated with adoption according to theory (Rogers, 1995). In this study, complexity is measured by cost and construction. These factors could prevent scale of the number of people who could potentially benefit from new technology. The potential for scale is high given the number of processors smoking fish in Ghana and local (and regional) consumer demand for smoked fish. Results from this study point to other socio-economic benefits of improved fish smoking technology through improved quality, food and occupational safety.

\section{Themes}

Cross-cutting themes present in both case studies relate to gender, food security and biodiversity. The role of gender varies by node. In The Gambia, men dominate the fisher and buyer node, whereas in Ghana, women dominate the processor node. Women are primarily involved in processing and marketing of fish on land. Many women fish processors in The Gambia stated they had never or rarely been interviewed about their work, whereas fishermen were more accustomed to being interviewed or asked to provide data about their work.

Innovations in both nodes (ice and ice coolers and smoking technology) contribute to food security in the same way, by extending shelf-life so different 
markets (export and domestic) benefit from consuming and trading it. With respect to marine and terrestrial biodiversity, the processor node is directly impacted (cost and supply) by loss of trees used as fuelwood to smoke fish. All nodes are threatened by loss of marine biodiversity; therefore, innovations must align with sustainable management of marine resources. The learning and evaluation component of the value chain upgrading framework (Figure 1.1) can control for negative impacts or unintended consequences but places no guarantee.

Other themes that emerge in both studies relate to equity, or distribution of benefits between nodes along the chain, as well as food and occupational safety with respect to improved fish smoking technology. The concept of equity emerged in chapter 2 between the fisher and buyer node. Results indicate economic benefits of using ice and ice coolers is accrued by buyers purchasing sole for export, not fishers for whom the innovation is designed around. Buyers benefit from fisher's use of ice. Buyers do not incur the additional cost of ice because they are provisioned with ice from the processing plant in return for delivering fish, whereas, fishers pay for ice. Therefore, as stated previously, for fishers the cost of ice exceeds the difference in revenue earned on average for fishers using ice just for sole. This result contributes to the growing literature on distribution of economic benefits within the value chain. We also learned fishers are vulnerable to cheating when selling their catch. By weighing the catch together during the six-week study period, fishers learned that they were entitled to participate in this process and even discussed collectively purchasing a scale, thus becoming less dependent on the buyers recorded weight of catch. 
These results raise equity concerns but also create leverage points (e.g. fishers commanding a premium price for iced sole in The Gambia). Food and occupational safety are central to the design and implementation of value chain improvements. Innovations that control temperature of fish in tropical regions can prevent growth of microorganisms and histamine-producing bacteria that accumulate in fish and compromise food safety. Occupational safety with respect to value chain innovations is a theme that emerged in chapter 3 but is also applicable to the innovation discussed in chapter 2. In chapter 3, dermal absorption of PAHs while smoking fish is potentially an occupational safety concern. In chapter 2, ice coolers were a newly introduced piece of equipment on-board fishing canoes. At the time, it was unclear how this equipment would affect stability of the canoe or interfere with the crew's mobility on-board the canoe. Therefore, to ensure safety-at-sea, life jackets were issued to each pilot participant and their crew in this study. Innovations that improve equity along the chain, food and occupational safety should be logistically feasible to implement and financially affordable.

Based on these studies, there are additional refinements that could improve the value chain upgrading framework (Figure 1.1). The innovation, for example, should accommodate or adapt to multi-species fisheries. Small-scale fisheries in developing countries harvest multiple species at the same time (Berkes, 2003). In this study, ice coolers and fish smoking stoves accommodate multiple species but minor adjustments are needed (e.g. increase storage capacity of ice coolers for sole and build trays with different mesh size to smoke different types of fish). Emphasis should be placed on 
low-cost, locally manufactured innovations in order to maximize adoption and scaleup.

\section{Discussion}

The theory behind upgrading small-scale fisheries in West Africa is to optimize usage of renewable natural resources through innovative, post-harvest value chain solutions. This research examines innovations that reduce post-harvest qualityrelated loss and loss of inputs (e.g. fuelwood) via product upgrading. Not only does quality-related loss of fish and waste of inputs (e.g. fuelwood, labor) prevent maximum use of scarce resources, it also reduces quality and arguably quantity of nutritious food that can result in economic loss, expressed as lower prices. Loss of food, especially such an important source of protein, has financial, food safety and security implications for those along the chain and ultimately, for consumers. The upside of reducing loss and improving product quality is potentially more meals served and income earned. The downside leads to a vicious cycle that affects some more than others. This cycle includes loss of nutrients and foregone revenue.

A recent article in Nature argues nutrition-sensitive fisheries policies are urgently needed in many developing countries that depend on fish for food because they have fewer options to compensate for lost nutrients (Golden, Allison, Chueng, Dey, Halpern, McCauley, \& Myers, 2016). This is especially true for West Africa which is highly dependent on fish as an affordable source of protein and faces depleting fishery resources (Golden et al., 2016). Golden et al. (2016) attributes fishcatch decline to weak governance, illegal fishing, population and climate change. In this case, maximizing quality of fish within each node along the chain is one strategy 
to mitigate the impact of declining fish stocks while better fisheries management is needed to sustain long-term benefits. Management deficiencies give rise to other coping strategies to make up for declining catches, including increased fishing effort. According to Akande and Diei-Ouadi (2010), "fishers will increase fishing effort to compensate for the lost income due to quality loss” (p.28). Therefore, it is important to address post-harvest loss within the context of fisheries management decisions.

This research contributes to growing literature on the value chain approach to upgrade small-scale fisheries. In theory, this approach aims to capture more value along the chain by cutting costs or through product differentiation (e.g. creating different and presumably better products relative to the status quo). The overarching goal is to increase profits. This is not uncommon or unrealistic expectation for anyone in business, but in practice, how and for whom does this work in small-scale fisheries in West Africa?

Socio-economic outcomes of value chain upgrades vary by node in this study. In The Gambia, the innovation undertaken, or use of ice and ice coolers reduced postharvest quality loss of sole within the fisher and buyer node. Overall, fishermen using ice on-board lost 14 percent less sole (based on weight in $\mathrm{kg}$ ) on average than fishermen not using ice. However, within the fisher node, the cost of ice exceeded the difference in revenue earned on average. Hence, for fishers it appears there is no economic incentive to purchase ice just for sole at the current market price. Fishers did not economically benefit from the innovation because the cost of ice exceeded the difference in revenue earned from using ice. The innovation did, however, have a statistically significant positive economic impact for export buyers, another node. On 
average, a buyer purchasing sole for export from a fisherman using ice lost less than one percent during the study period This finding provides empirical evidence on distribution of benefits from diffusing an innovation. O’Neill and Crona (2017) highlight the need for data on distribution of economic benefits in small-scale fisheries. The innovation did not appear to economically impact local trade of sole within the processor node.

In the case of the Gambian sole fishery, results also validate that small-scale fisheries in developing countries rarely discard fish. Yet, their catch is often subject to down-grades or sold at a reduced price that results in foregone revenue. A new term, export loss, is introduced in this study to capture this phenomenon. Export loss is defined as product that does not meet export quality standards and fails to achieve export trade earnings. As supplies of fish from developing countries to the international market increase, so will revenue from trade. Export markets may require higher product quality standards or compliance with certification and traceability schemes, in other words product upgrading, as defined by Riisgaard, Bolwig, Ponte, Du Toit, Halberg, and Matose (2010). Export revenues from fish trade contribute to national and local economies in developing countries (Bostock, Greenhalgh \& Kleih, 2004). Béné, Lawton and Allison (2010), however, remind us that wealth generated through trade may not necessarily trickle down to those extracting resources. Future research could quantify export loss in small-scale fisheries (in relation to gross domestic product) in countries dependent on fisheries in terms of trade. Thorpe, Reid, Van Anrooy, and Brugere (2005) hypothesize in countries where fisheries enhance trade, they are more likely to be incorporated into national economic development 
plans (e.g. poverty reduction strategy papers) and less likely to be marginalized (as a sector through policies). Thorpe et al. (2005) conclude countries such as Peru and Philippines with high dependence on fisheries in terms of trade (and consumption) are integrated into national growth and poverty reduction strategies.

Other economic benefits, while not realized in this study, point to price premium for better quality fish. Anecdotal evidence from the Gambian sole study suggests buyers would like to buy iced sole from fishers. Seeking price premiums in small-scale developing world fisheries can be problematic if it attracts more people in the fishery (e.g. result of open access fishery) or negatively impacts low income consumers with higher priced fish. The FAO suggests policy interventions that mitigate the effects from price increases including access to alternative cheap protein, but does not specify type of protein (Akande \& Diei-Ouadi, 2010). Alternatives with potential downsides that warrant further examination include like-species substitution (e.g. comparable economic and nutritive value) from imports or aquaculture.

In Ghana, a direct economic and environmental benefit of the innovation undertaken is less consumption of fuelwood, a cost-saving. Fuelwood is a primary input cost to smoke fish. Non-economic benefits of this innovation relate to occupational safety and ease of work within the processing node. This node is exposed to excessive exposure to smoke using traditional fish smoking techniques. New research suggests dermal absorption is also a significant intake pathway of PAHs contaminants (Lao, Xie, Wu, Bao, Tao, \& Zeng, 2018). Evidence from research in Ghana suggests less coughing and smoke nuisance are factors that influence adoption of the ahotor stove. More downstream coordination and communication with 
consumers about the health benefits of fish smoked by the ahotor stove may help processors improve return on investment of innovations.

The small-scale fisheries value chain can learn from small-scale farmers in Ghana. A new variety of pineapple was introduced to small-scale farmers to help exporters, another node, meet changing demands from international markets through government and academic institutions in Ghana. With the help of an international loan, the Ministry of Agriculture and the University of Ghana subsidized the cost of a new variety of pineapple (MD2) and controlled quality in order to increase exports of this new variety and avoid losing market share (Röling, 2010). Access to inputs such as fertilizer, transportation and credit also helped small-scale farmers in Ghana gain relevance in the marketplace for non-export crops (Röling, 2010).

Thorpe and Bennett (2004) highlight that much of the literature on fishery value chains focus on export-oriented fish commodities and Thilsted, Thorne-Lyman, Webb, Bogard, Subasingle, Phillips, and Allison (2016) and Bene, Abban, AbdelRahman, Ayyappan, Brummett, Dankwa, Habib, Katiha, Kolding, Obiririh-Opareh, Orori, Shehata, Shrivastava and Vass (2009) suggest fisheries value chains comprised of low-value species processed primarily by women for local and regional trade warrant closer attention. This research contributes to both by implementing innovations at different nodes along the value chain each with different end markets. Deciding which node to upgrade is an important consideration with respect to food safety, optimal usage and equity. Fish is highly perishable. Shelf-life begins the moment fish is immobilized by a net or trap or removed from water. Shelf-life ends when fish is determined no longer fit for consumption. In tropical fisheries, 
implementing innovations immediately after harvest is a good starting point for extending shelf-life of fish products. This analysis indicates that improvements to chilling, freezing, smoking, salting or drying processes and more modern methods such as modified atmosphere packaging-where applicable-help to preserve fish for a longer period of time so that more people can benefit from consuming or trading it. Value chain innovations, however, benefit some more than others in the value chain as evidenced by the Gambian case study. Therefore, ways to distribute, or share the cost of implementation should be evaluated.

This research aims to level the playing field by creating conditions that promote equitable economic growth among nodes in the chain regardless of the end market. In essence, it tries to avoid creating "winners and losers," a phrase often associated with property rights in fisheries. Once fish is out of the water, it is important to be mindful of markets and margins. For example, innovations intended to benefit the export market should not jeopardize supply of fish to the local market. Likewise, innovations that aim to improve profit margins might benefit those earning the least in the chain, but that is not a guarantee.

The value chain approach aims to increase profits, but it is also important to acknowledge why this approach might fail to benefit certain nodes along the chain. This approach gave us a lens into poverty. Being aware of the economic lives and conditions of fisherfolk may lay the ground work for implementing equitable innovations in the fisheries value chain. Designing innovations around weaker ${ }^{1}$ nodes might help strengthen the chain as a whole. In fisheries for example, designing

\footnotetext{
${ }^{1}$ A term used by Bolwig et al. (2010) that includes artisanal fishers.
} 
innovations around nodes that record high post-harvest loss could yield more fish for direct human consumption, a benefit to the entire chain. This notion conflicts with the value chain concept popularized by Porter (1985). Since then, Porter stresses the importance of shared value that benefits both business and society (Porter \& Kramer, 2006). I propose extending the concept of shared value beyond corporations to coastal fishing communities and to equalizing value along the chain thus creating a balanced win. An immediate implication of this expansion is shifting and equalizing the balance of power that exists within the supply chain by understanding how their markets function. For example, by weighing the catch together, transparency and collaboration between fishers and buyers increased as evidenced in chapter 2. Exploring costsharing opportunities with other value chain actors may offset the cost of ice incurred by Gambian fishers in exchange for better quality fish reducing export loss.

Factors that influence adoption of the ahotor stove are the focus of chapter 3. A model predicts technology plus simplicity with respect to cost and constructioninfluence adoption of the ahotor stove. Simplicity and affordability are crucial when designing and implementing innovations in small-scale fisheries. Innovations that are mobile (e.g. easily moved) and adapt to multi-species fisheries are a plus within the fisher and processor node. For example, ice coolers used by fishers and buyers in The Gambia (and Senegal) are locally manufactured, mobile, adapt to multi-species and modestly priced ( 15 USD). For processors, the ahotor stove is not mobile nor modestly priced. The ahotor stove can be manufactured in every community, but artisans (or processors) must be trained to build it. The ahotor stove can also adapt to 
multiple species but that requires replacing mesh size and depth of trays used to smoke fish.

Catch fluctuates seasonally and differ year-to-year in capture fisheries, therefore, innovations designed around fisher and processor nodes should be capitalsensitive, not intensive requiring significant cash outlay. Allison and Ellis (2001) caution capital-intensive interventions can lead to increased fishing effort if users are unable to earn sufficient returns on the investment. This not only compromises resource sustainability but also personal safety-at-sea if fishers take higher risks in order to re-pay a capital-intensive investment.

Innovations introduced within any node should not be confused with incentives that can lead to overexploitation. In open access fisheries like Ghana, diffusing innovations within the fisher node, or those closest to the resource is risky if the innovation contributes to overfishing. In the past, a series of innovations within the fisher node in Ghana have contributed to overfishing of small pelagic species in absence of harvest and input control measures. Motorized canoes were first introduced in 1946 (Nunoo et al., 2014), followed by monofilament nets. Today, the capacity of these innovations is enhanced by a fuel subsidy to small-scale fishers targeting small pelagic species. The impacts of the fuel subsidy program are discussed by Tobey, Normanyp, Osei, Beran, and Crawford (2016). In theory, innovations that aim to increase profit should be nested into larger fisheries improvement or development projects to control for unintended consequences such as overfishing.

Implementing innovations in short supply chains comprised of a single species is prudent when first using the value chain upgrading framework (Figure 1.1). Shorter 
supply chains of single species (e.g. Gambian sole) are easier to map than multispecies fisheries with complex supply chains (e.g. small pelagics in Ghana). The Gambian sole fishery differs by size and management from the small pelagic fishery in Ghana. According to a frame survey conducted in 2015 by the Department of Fisheries in The Gambia, there are 175 canoes fishing for sole along Gambia’s 80 km coastline. While in Ghana, approximately 12,000 artisanal canoes harvest small pelagic species along the $550 \mathrm{~km}$ coastline (Nunoo et al., 2014). The Gambian sole fishery went from little to no management in 2008 to a special management area for sole with a management plan to a Fishery Improvement Project. These management measures do not guarantee that innovations will not become perverse incentives that lead to overfishing, but they do provide some assurance, especially given the relatively small size of the Gambian sole fishery. Hence, introducing innovations to fisher nodes should be evaluated on a case-by-case basis in fisheries with management controls in place. In value-added export fisheries like Gambian sole, diffusing an innovation that reduces export loss is a starting point, albeit fewer benefit.

Finally, upgrades that make use of existing, functioning infrastructure will facilitate implementation and adoption. For example, in The Gambia there are two functioning ice plants that sell crushed ice at fish landing sites. In Ghana, ice is sold in blocks within communities but there is limited use of the cold-chain for processing of small pelagic species. However, fish smoking infrastructure such as smoking houses and drying racks are in place and used by many. 


\section{Conclusion}

The chapters presented in this dissertation address ways to upgrade nodes in small-scale fisheries by implementing post-harvest innovations. The first chapter provided an overview of the theoretical concepts used to reduce post-harvest quality loss of fish, improve usage of fish and fuelwood within nodes in small-scale fisheries and upgrade nodes by diffusing an innovation. Chapter 1 introduced a framework to design innovations that result in adoption. Chapter 2 assessed post-harvest quality loss of sole in The Gambia within the fisher and buyer node. Chapter 3 measured adoption of improved smoking technology within the processor node in Ghana. This chapter summarizes results as they pertain to each case study based on the overarching questions of this study.

First, the theory behind upgrading small-scale fisheries in West Africa differ by node and end market. In the Gambian sole study, the theory behind upgrading the fisher node by diffusing an innovation (e.g. ice and ice coolers on-board fishing canoes) is to reduce export loss of sole, or product that does not meet export quality standards and is subsequently sold at a reduced price that results in foregone revenue. In the Ghana, the theory behind upgrading the post-harvest processor node by diffusing an innovation (e.g. ahotor stove) is to improve processing methods (e.g. less smoke emission and smoke deposit on fish) and profitability (e.g. less consumption of fuelwood and better price for improved quality) of fish for domestic sale and consumption. The theory behind upgrading these nodes, which are closest to the resource is to help strengthen the chain further along. For example, improved chilling or smoking techniques preserve fish for a longer period of time so that more people can benefit from trading and ultimately consuming it. In theory, innovations that 
upgrade one node should not jeopardize quality or supply of fish to another node. The goal behind upgrading post-harvest small-scale fisheries is to equalize value along chain thus creating a balanced win.

Second, summarizing socio-economic outcomes of value chain upgrades in the Gambia concludes that ice improves quality and reduces export loss of sole. Fishers using ice and ice coolers on-board canoes lost 14 percent less sole by weight $(\mathrm{kg})$ on average due to quality than fishers not using ice on-board canoes. The difference is statistically significant ( $\mathrm{p}-$ Value $<0.001, \mathrm{t}=7.25, \mathrm{df}=566$, one-tailed). The cost of ice to fishers, however, exceeded the difference in revenue earned from sole on average. Therefore, based on the current market price of sole and ice, there is no economic incentive for fishers to purchase ice just for sole. Non-economic benefits realized by fishers included better fuel efficiency, improved hygiene and cleanliness on-board and quicker off-loading of fish upon landing. Fisher's use of ice had a statistically significant positive impact on the buyer's loss of sole due to quality which was less than one percent ( $\mathrm{p}$-Value $=0.05, \mathrm{t}=1.64, \mathrm{df}=546$, one-tailed test). A buyer's average daily revenue from purchasing sole from fishers using ice nearly doubled during the 6week study period. In this case, the buyer node benefited more than the fisher node for whom the innovation was designed to benefit. These outcomes align with theory in that the innovation reduces export loss and improves preservation of fish. However, the innovation did not achieve a balanced win between the fisher and buyer node, although it did not negatively impact local trade and consumption of sole processed primarily by women. 
Socio-economic outcomes of value chain upgrades in Ghana indicate the ahotor stove improves processing methods and points to increased profitability of smoked fish within the processor node. The ahotor stove is more fuelwood-efficient than the chorkor, or current stove widely used in Ghana to smoke fish. According to a study conducted by CSIR et al. (2016), mean difference for fuelwood consumption between stoves is statistically significant $(t=9.51, \mathrm{df}=2)$. Specific design features ${ }^{2}$ of the ahotor stove are shown to reduce polycyclic aromatic hydrocarbons ${ }^{3}$ (PAHs) based on chemical analytical tests using limited samples. These design features prevent excessive exposure to heat and smoke among fish processors. The majority of fish processors using the ahotor stove $(92 \%, \mathrm{n}=37)$ state they experience less coughing while using it compared to the previous stove used (chorkor). Economic outcomes of using the ahotor stove point to increased profitability within this node. An overwhelming majority of those using the ahotor stove state less money is spent on fuelwood using this stove versus the chorkor stove, whereas 5 percent state they do not know. The difference between the ahotor and chorkor stove with respect to money spent on fuelwood is statistically significant $\left(\chi^{2}=27.10, \mathrm{df}=2, \mathrm{n}=102\right.$, $\mathrm{p}-\mathrm{V}$ alue $<0.001$, Cramer's V=0.52, Contingency coefficient $=0.46$ ). Those using the ahotor stove state their fish sells faster at the market than fish smoked by the chorkor stove. The difference by stove type with respect to sales of fish at the market approaches significance $\left(\chi^{2}=3.70, \mathrm{df}=1, \mathrm{n}=105, \mathrm{p}\right.$-Value $=0.05$, Fisher Exact Test two-tailed

\footnotetext{
${ }^{2}$ Specific design features include a twin combustion chamber, oil drip collector and a hood with a cut-out hole to deter smoke away from the operator.

${ }^{3}$ Polycyclic aromatic hydrocarbons are carcinogenic and genotoxic substances that pose potential food safety and health hazard concerns (European Food Safety Authority, 2008).
} 
$\mathrm{p}=0.07$ ). An ordinal rank test reveals statistically significant differences between stoves with respect to quality of smoked fish (Kruskal-Wallis $=6.72$, $\mathrm{df}=1, \mathrm{p}=0.01$ ). Those using the ahotor stove perceive it produces better quality smoked fish than fish smoked by the chorkor stove based on a median score of 1.00 and .50, respectively. These findings are consistent with the goal behind the design of the ahotor stove. These economic outcomes do not confirm increased profitability but point to its potential. These outcomes could potentially benefit fish processors economically in Ghana. The outcomes align with the theory behind upgrading this node, which is to improve processing methods and increase profitability.

Third, factors that influence adoption of the ahotor stove in Ghana are less consumption of fuelwood, hence, cost of fuelwood, less smoke nuisance (to the eyes), interest in the stove expressed by other fish processors and trainings on use of the stove. Factors that influence adoption are summarized in one meta-variable named technology. Complexity measured by construction and maintenance of the ahotor stove factors in negatively. Access to or possession of luxury items, a proxy for wealth, is another factor that influences adoption of the ahotor stove. A logistic regression model suggests technology plus simplicity and wealth, or luxury items are the most significant predictors of adoption of the ahotor stove (Coefficient significant at $<0.001$ and 0.05 level, respectively). This study did not determine factors that influence adoption of ice and ice coolers used within the fisher node for Gambian sole. We assumed the relative low cost of construction and ease of construction of ice coolers would be an incentive rather than a barrier to adoption, however, we learned that there is no economic incentive for fishers to purchase ice just for sole. Therefore, we concur 
that the degree of benefit (of an innovation) is an important factor for adoption as stated by Rogers (1995).

\section{Practical implications}

This dissertation demonstrates the importance of upgrading small-scale fisheries to achieve equitable economic growth, improve food and occupational safety, and alleviate poverty by diffusing a post-harvest innovation. Findings from this research enhance the FAO’s (2015) Voluntary Guidelines for Securing Small-scale Fisheries in the Context of Food Security and Poverty Alleviation and Sustainable Development Goals (United Nations, 2016) through multiple lessons learned that relate to energy efficiency, post-harvest loss and value addition, distribution of economic benefits along the chain, gender and occupational safety within the postharvest fish processing sector. Practical implications of this research are directed at policy makers, practitioners and industry to consider during implementation of postharvest innovations. Practical implications are listed as recommendations and discussed in relation to sections within The Guidelines (FAO, 2015) and Sustainable Development Goals (United Nations, 2016).

The FAO’s PHLA (Akande \& Diei-Ouadi, 2010) which updated Ward and Jeffries (2000) manual for assessing post-harvest fisheries losses identifies three main types of loss, physical, quality and market-force. The FAO’s PHLA (Akande \& DieiOuadi, 2010) is widely used to generate fish loss data and guide implementation of the FAO’s Code of Conduct for Responsible Fisheries. This dissertation identified another type of loss, export loss. The amount lost to export may be significant in countries dependent on fisheries for trade, therefore, it is recommended to account for export 
loss in small-scale fisheries with export markets. A revision of the FAO's PHLA (Akande \& Diei-Ouadi, 2010), future manual or step within the value chain upgrading framework (Figure 1.1) could account for this type of loss, especially as supplies of fish from small-scale fisheries to the international market increase.

When implementing post-harvest innovations that benefit the export market, it is important to consider the potential impact it may have on the local market and consumption of fish. The Guidelines acknowledge this in section 7.7 (FAO, 2015), however, provide no means of verification. This study considered the impact of an export-oriented value chain improvement on local trade and consumption of sole by administering a field survey among local women processors in The Gambia. Results from this study indicated that the innovation did not impact either. Therefore, it is recommended to consult reliable, representative key informants when implementing value chain improvements that benefit the export market to gain some assurance that it doesn’t impact the local market.

The value chain approach aims to increase profits by node, however, it is important to understand distribution of economic benefits between nodes along the chain. Unequal distribution of benefits shifts the balance of control within the value chain as evidenced in this study. As stated previously, Gambian sole fishers were dependent on buyers to weigh and purchase their catch which make them vulnerable to cheating. By weighing the catch together during the 6-week study period, transparency and collaboration between these nodes increased.

The value chain approach also provided us with a lens into poverty as evidenced during implementation of the ahotor stove in Ghana. Poverty is multi- 
faceted. In this context, drivers of poverty include economic hardship caused by a steady decline in marine capture fisheries combined with single, female-headed households with large family sizes (Friends of the Nation [FoN], 2015; Beran \& Crawford, 2018). Under the premise that economic hardship is a driver of poverty, a subset of fish processors referred to as vulnerable households in this study received a fully subsidized ahotor stove to generate income. This research validates section 7.1 of The Guidelines, that vulnerable groups in fisheries require special support (FAO, 2015).

There are multiple opportunities to design post-harvest innovations that reduce post-harvest loss and add value to fish along the chain in small-scale fisheries. The innovations examined in this dissertation are the ahotor stove used by processors in Ghana and insulated coolers used by fishers in The Gambia. Both innovations achieve their purpose. The purpose behind the ahotor stove is to reduce fuelwood consumption while producing better quality smoked fish for the domestic market. Achieving this purpose advances section 7.5 of The Guidelines (FAO, 2015) and Goal 7 of the SDGs (United Nations, 2016) that advocate building on traditional and local innovations that reduce waste of inputs, specifically fuelwood, and advocate energy efficiency in the value chain, respectively. The purpose behind insulated coolers is to improve quality of sole for export and reduce export loss. Achieving this purpose advances section 7.3 and 7.5 of The Guidelines (FAO, 2015), to produce good quality, safe fish for export markets and avoid post-harvest loss in small-scale fish handling and processing, respectively. Implementing innovations in small-scale fisheries, however, is not straight forward. Results from this study recommend that fuel-efficient innovations 
should be simple to build, easy-to-use and affordable to buy within the context of small-scale fisheries.

The post-harvest fish processing sector in The Gambia and Ghana, as elsewhere, is dominated by women. This study showed that on average, individual women have processed fish for a quarter of a century while the tradition of fish processing and fish trading extends back in time to the early 1900s (Walker, 2002). Processing fish is an important economic activity for women. Both case studies indicate women are dependent on fish processing for income generation. Their dependence on fish processing for income combined with their knowledge of fisheries make them a key-yet underutilized-stakeholder. In addition to recognizing the role of women, it equally important to elevate their status in this sector with respect to gender equality, or Goal 5 of the 2030 Agenda for Sustainable Development (United Nations, 2016) and section 8 within The Guidelines (FAO, 2015). Therefore, it is recommended to increase participation of women as decision-makers in management of renewable natural resources.

This research shows fish processors-many of whom are women-are exposed to excessive amounts of smoke from traditional smoking stoves. In many cases, children are nearby and thereby also exposed to excessive amounts of smoke. This is an occupational safety concern and potential health hazard according to a recent study that suggests dermal absorption is a significant intake pathway of PAHs. Improved smoking technology such as the ahotor stove offers personal health benefits such as less coughing and smoke nuisance to the eyes. The Guidelines (FAO, 2015) stress the importance of occupational health issues as an integral part of fisheries management 
but do not provide details of specific health issues (FAO, 2015, section 6.12). Therefore, it is recommended to conduct further research on excessive exposure to smoke to ensure worker’s safety-on-land.

\section{Theoretical implications}

The outcomes of value chain upgrades in this research have theoretical implications with respect to the post-harvest loss assessment (PHLA) and value chain approach and diffusion theory.

Over time, Porter’s (1985) value chain concept has evolved from maximizing value, or profit, within the chain to shared value along the chain (Porter \& Kramer, 2006). Both innovations presented in this research align with the goal behind Porter's approach, which is to create value and optimize usage of a product or good. The innovation designs presented in the Gambian and Ghana case studies, however, challenge Porter's description of innovations to outperform competitors by using capital-intensive and state-of-the-art technology. In the context of this research, less (cost and complexity) is more. The case studies presented in this dissertation highlight the double-edged nature of technology and innovation. To innovate requires capital, however, in small-scale fisheries in the developing world, innovations should be capital-sensitive and tailored to the context and capacities of its users and their endmarkets. Socio-economic outcomes of this research align more closely with Porter and Kramer's (2006) vision of shared value along the chain. For example, the Gambian sole study contributes to the growing literature on distribution of profits, or revenue from sales of fish. Rosales et al. (2017) similarly propose ways to enhance the value of 
catch so primary harvesters get a fairer share. These studies suggest further expansion from shared value toward more equitable distribution along the chain.

This study measured post-harvest quality-related fish loss using elements of the PHLA. This study identified another type of loss, or export loss not addressed by the PHLA approach but could potentially expand it. In specific, I contend that smallscale fisheries from developing countries with export markets should account for export loss. This is an important policy development driver for two reasons. First, assessing export loss contributes to our understanding of the potential economic value of small-scale fisheries with established export markets. The potential economic value is the value derived if there is no export loss. Second, this information may be useful to fisheries managers, policy makers and the private sector alike who may push to put in place measures that protect valuable resources and prevent post-harvest losses motivated by the potential economic value of the fishery. This information may also lead to investments that strengthen the post-harvest sector or nodes along the chain. Finally, quick and cost-effective ways to measure nutritional loss are also needed given its relevance to food security and poverty alleviation in small-scale fisheries.

Factors that influence adoption of improved fish smoking stoves align with perceived attributes of innovations according to diffusion theory. Socio-economic characteristics of adopters of the ahotor stove also align with theory. According to theory and evidenced in this study, early adopters are more likely to be literate, educated and have higher social status indicated by possession of wealth and standard of living. In this study, male aquaculture farmers serve as an example of an early adopter of the ahotor stove. In this case, the innovation spread beyond the targeted 
audience, or was “auto-diffused," a term used by Rogers (1995). This illustrates the innovativeness-needs paradox discussed by Rogers (1995) whereby those who adopt first typically have the least need with respect to benefits of the innovation. One aspect of this research that contributes to diffusion theory is the idea that one meta-variable, or technology plus simplicity, may predict adoption. Diffusion theory has relied on five standardized attributes of innovations, four of which-except complexity-are somewhat empirically related although conceptually different (Rogers, 1995). Results from this research suggest a combination of attributes are empirically related. Future research could predict adoption using one meta-variable named technology plus simplicity.

\section{Next step}

Thematic areas for future research relate to food safety, trade and fisheries management. Additional research (e.g. structured trials) is needed to understand the health impact of PAHs on consumers of smoked fish in West Africa and elsewhere traditional smoking techniques are employed. Results of this research could contribute to the FAO's Codex Alimentarius Code of Practice for the Reduction of Contamination of Food PAHs from smoking and Direct Drying Processes (CAC/RCP 68-2009). With respect to trade, future research could examine the impact of export loss on poverty alleviation and food security in countries dependent on fisheries with export markets. Finally, future research might investigate if adding value to fish products is an incentive for better fisheries management within small-scale fisheries in developing countries. Future research might examine how reducing loss of fish 
contributes to food equity or better fisheries management within small-scale fisheries in developing countries. 


\section{References}

Akande, G., \& Diei-Ouadi, Y. (2010). Post-Harvest Losses in Small-scale Fisheries: Case Studies in Five sub-Saharan African Countries. FAO Fisheries and Aquaculture Technical Paper, (550).

Allison, E. H., \& Ellis, F. (2001). The Livelihoods Approach and Management of Small-scale Fisheries. Marine Policy, 25(5), 377-388.

Anderson, J. L., Anderson, C. M., Chu, J., Meredith, J., Asche, F., Sylvia, G., . . . Guttormsen, A. (2015). The Fishery Performance Indicators: A Management Tool for Triple Bottom Line Outcomes. PloS One, 10(5), e0122809.

Béné, C., Abban, E., Abdel-Rahman, S., Ayyappan, S., Brummett, R., Dankwa, H., Kolding, J. (2009). Improved Fisheries Productivity and Management in Tropical Reservoirs. CPWF Project number 34. CGIAR Challenge Program on Food and Water Report Series. www.waterandfood.org.

Béné, C., Lawton, R., \& Allison, E. H. (2010). “Trade Matters in the Fight Against Poverty": Narratives, Perceptions, and (lack of) Evidence in the Case of Fish Trade in Africa. World Development, 38(7), 933-954.

Beran, K., Crawford, B. (2018). Assessment of Ahotor Stove Grants on Households Vulnerable to Child Labor and Trafficking. The USAID/Ghana Sustainable Fisheries Management Project (SFMP). Narragansett, RI: Coastal Resources Center, Graduate School of Oceanography, University of Rhode Island and CEWEFIA and DAA. 30 pp.

Berkes, F. (2003). Alternatives to Conventional Management: Lessons from Smallscale Fisheries. Environments, 31(1), 5.

Bostock, T., Greenhalgh, P., \& Kleih, U. (2004). Policy Research-Implications of Liberalisation of Fish Trade for Developing Countries: Synthesis report.

Bolwig, S., Ponte, S., Du Toit, A., Riisgaard, L., \& Halberg, N. (2010). Integrating Poverty and Environmental Concerns into Value-Chain Analysis: A Conceptual Framework. Development Policy Review, 28(2), 173-194.

Codex Alimentarius Commission. (2009). Code of Practice for the Reduction of Contamination of Food with Polycyclic Aromatic Hydrocarbons (PAH) from Smoking and Direct Drying Processes. Cac/rcp, 68.

European Food Safety Authority. (2008). Polycyclic Aromatic Hydrocarbons in Food. Scientific Opinion of the Panel on Contaminants in the Food Chain. European Food Safety Authority Journal 724, 114p.

Fafanding, S. F., Tobey, J., \& Drammeh, O. (2010). Sole Fishery Value Chain Assessment. Narragansett, RI: Coastal Resources Center, University of Rhode 
Island. Retrieved

from http://www.crc.uri.edu/download/Final_Sole_VCA_Report_August_201 01.pdf

Fishery Progress. (2018). Gambia Sole-Bottom Set Gillnet. Retrieved August 12, 2018 from https://fisheryprogress.org/fip-profile/gambia-sole-bottom-set-gillnet.

Food and Agriculture Organization of the United Nations. (2015). Voluntary guidelines for securing sustainable small-scale fisheries in the context of food security and poverty eradication. Food and Agriculture Organzation of the United Nations. Rome.

Food and Agriculture Organization of the United Nations (FAOb). (2015). The Global Forest Resources Assessment. ( No. ISBN-978-92-5-108826-5). Rome. Retrieved from http://www.fao.org/3/a-i4808e.pdf

Friends of the Nation (2015). The USAID/Ghana Sustainable Fisheries Management Project (SFMP), Anti-Child Labour and Trafficking Field PRA Survey Report. Narragansett, RI: Coastal Resources Center, Graduate School of Oceanography, University of Rhode Island. 90p.

Golden, C., Allison, E. H., Cheung, W. W., Dey, M. M., Halpern, B. S., McCauley, D. J., ... Myers, S. S. (2016). Fall in Fish Catch Threatens Human Health. Nature, 534 (7607), 317-320.

Kwarteng, E. (2015). Fuelwood Value Chain Analysis Literature Review Report. The USAID/Ghana Sustainable Fisheries Management Project (SFMP).Narragansett, RI: Coastal Resources Center, Graduate School of Oceanography, University of Rhode Island and SNV Netherlands Development Organization.GH2014_SCI010_SNV. 91pp.

Lao, J., Xie, S., Wu, C., Bao, L., Tao, S., \& Zeng, E. Y. (2018). Importance of Dermal Absorption of Polycyclic Aromatic Hydrocarbons Derived from Barbecue Fumes. Environmental Science \& Technology, 52(15), 8330-8338.

Nunoo, F., Asiedu, B., Amador, K., Belhabib, D., Lam, V., Sumaila, R., \& Pauly, D. (2014). Marine Fisheries Catches in Ghana: Historic Reconstruction for 1950 to 2010 and Current Economic Impacts. Reviews in Fisheries Science \& Aquaculture, 22(4), 274-283.

O'Neill, E. D., \& Crona, B. (2017). Assistance Networks in Seafood Trade-A Means to Assess Benefit Distribution in Small-scale Fisheries. Marine Policy, 78, 196-205.

Porter, M. E. (1985). Competitive Advantage: Creating and Sustaining Superior Performance. The Free Press. New York.

Porter, M. E., \& Kramer, M. R. (2006). The Link Between Competitive Advantage and Corporate Social Responsibility. Harvard Business Review, 84(12), 78-92.

Riisgaard, L., Bolwig, S., Ponte, S., Du Toit, A., Halberg, N., \& Matose, F. (2010). Integrating Poverty and Environmental Concerns into Value-Chain Analysis: 
A Strategic Framework and Practical Guide. Development Policy

Review, 28(2), 195-216.

Röling, N. (2010). The Impact of Agricultural Research: Evidence from West Africa, Development in Practice, 20:8, 959-971, DOI:

10.1080/09614524.2010.513724.

Rogers, E. M. (1995). Diffusion of Innovation. Fourth edition. The Free Press. New York.

Rosales, R. M., Pomeroy, R., Calabio, I. J., Batong, M., Cedo, K., Escara, N., ... Sarahadil, M. (2017). Value Chain Analysis and Small-scale Fisheries Management. Marine Policy, 83, 11-21.

Thilsted, S. H., Thorne-Lyman, A., Webb, P., Bogard, J. R., Subasinghe, R., Phillips, M. J., \& Allison, E. H. (2016). Sustaining Healthy Diets: The Role of Capture Fisheries and Aquaculture for Improving Nutrition in the post-2015 Era. doi:https://doi.org/10.1016/j.foodpol.2016.02.005

Thorpe, A., \& Bennett, E. (2004). Market-driven International Fish Supply Chains: The Case of Nile Perch from Africa's Lake Victoria. International Food and Agribusiness Management Review, 7(4), 40-57.

Thorpe, A., Reid, C., Van Anrooy, R., \& Brugere, C. (2005). When Fisheries Influence National Policy-making: An Analysis of the National Development Strategies of Major Fish-producing Nations in the Developing World. Marine Policy, 29(3), 211-222.

Tobey, J., Normanyo, A., Osei, P., Beran, K., \& Crawford, B. (2016). Subsidies in Ghana's marine artisanal fisheries sector. USAID/Ghana Sustainable Fisheries Management Project (SFMP). Narragansett, RI: Coastal Resources Center, Graduate School of Oceanography, University of Rhode Island.GH2014_POL059_CRC. 53pp.

Uchida, H. (2017). TURFs, Collective Fishery Management, and Fishery Cooperatives. Bulletin of Marine Science, 93(1), 83-99.

United Nations. (2016). Sustainable Development Goals Report. 2016. United Nations. New York.

Walker, B. L. E. (2002). Engendering Ghana's Seascape: Fanti Fish, Traders and Marine Property in Colonial History. Society \&Natural Resources, 15(5), 389407. 


\section{Bibliography}

Affognon, H., Mutungi, C., Sanginga, P., \& Borgemeister, C. (2015). Unpacking PostHarvest Losses in sub-Saharan Africa: A Meta-Analysis. World Development, 66, 49-68.

Akande, G., \& Diei-Ouadi, Y. (2010). Post-Harvest Losses in Small-scale Fisheries: Case Studies in Five sub-Saharan African Countries. FAO Fisheries and Aquaculture Technical Paper, (550). 77pp.

Akpambang, V., Purcaro, G., Lajide, L., Amoo, I., Conte, L., \& Moret, S. (2009). Determination of Polycyclic Aromatic Hydrocarbons (PAHs) in Commonly Consumed Nigerian Smoked/Grilled Fish and Meat. Food Additives and Contaminants, 26(7), 1096-1103.

Allison, E. H., \& Ellis, F. (2001). The Livelihoods Approach and Management of Small-scale Fisheries. Marine Policy, 25(5), 377-388.

Allison, E. H., Perry, A. L., Badjeck, M., Neil Adger, W., Brown, K., Conway, D., . . . Andrew, N. L. (2009). Vulnerability of National Economies to the Impacts of Climate Change on Fisheries. Fish and Fisheries, 10(2), 173-196.

Anderson, J. L., Anderson, C. M., Chu, J., Meredith, J., Asche, F., Sylvia, G., . . . Guttormsen, A. (2015). The Fishery Performance Indicators: A Management Tool for Triple Bottom Line Outcomes. PloS One, 10(5), https://doi.org/10.1371/journal.pone.0122809.

Asche, F., Bellemare, M. F., Roheim, C., Smith, M. D., \& Tveteras, S. (2015). Fair Enough? Food Security and the International Trade of Seafood. World Development, 67, 151-160.

Ascher, W., Brewer, G. D., Cheema, G. S., \& Heffron, J. M. (2016). Evolution of Economic Development Theories and Doctrines Since World War II. The Evolution of Development Thinking. Springer. 15-39pp.

Avega, B., \& Tibu, G. (2017). Performance Evaluation Survey (Ahotor oven). The USAID/Ghana Sustainable Fisheries Management Project (SFMP). Narragansett, RI: Coastal Resources Center, Graduate School of Oceanography, University of Rhode Island and Netherlands Development Organisation.GH2014_ACT099_SNV.33p.

Ba, A., Schmidt, J., Dème, M., Lancker, K., Chaboud, C., Cury, P., . . . Brehmer, P. (2017). Profitability and Economic Drivers of Small Pelagic Fisheries in West Africa: A Twenty-Year Perspective. Marine Policy, 76, 152-158. doi:https://doi.org/10.1016/j.marpol.2016.11.008. 
Bailis, R. (2004). Controlled Cooking Test. Version 2.0. Shell Foundation (Household Energy and Health Programme). https://cleancookstoves.org/binarydata/DOCUMENT/file/000/000/80-1.pdf.

Bair, J. (2008). Analysing Global Economic Organization: Embedded Networks and Global Chains Compared. Economy and Society, 37(3), 339-364.

Belhabib, D., Mendy, A., Zeller, D., \& Pauly, D. (2013). Big Fishing for Small Fishes: Six Decades of Fisheries in The Gambia "The Smiling Coast of Africa."

Banerjee, A. V., Banerjee, A., \& Duflo, E. (2011). Poor Economics: A Radical ethinking of the Way to Fight Gobal Poverty. Public Affairs. New York.

Barrientos, S., Gereffi, G., \& Rossi, A. (2011). Economic and Social Upgrading in Global Production Networks: A New Paradigm for a Changing World. International Labour Review, 150(3-4), 319-340.

Béné, C., Lawton, R., \& Allison, E. H. (2010). Trade Matters in the Fight Against Poverty: Narratives, Perceptions, and (lack of) Evidence in the Case of Fish Trade in Africa. World Development, 38(7), 933-954. DOI:

10.1016/j.worlddev.2009.12.010.

Béné, C., Abban, E., Abdel-Rahman, S., Ayyappan, S., Brummett, R., Dankwa, H., Kolding, J. (2009). Improved Fisheries Productivity and Management in Tropical reservoirs. CPWF Project number 34. CGIAR Challenge program on food and water report series. www.waterandfood.org.

Béné, C., \& Heck, S. (2005). Fish and food security in africa. NAGA, WorldFish Center Quarterly, 28(3-4), 8-13.

Beran, K., Crawford, B. (2018). Assessment of Ahotor Stove Grants on Households Vulnerable to Child Labor and Trafficking. The USAID/Ghana Sustainable Fisheries Management Project (SFMP). Narragansett, RI: Coastal Resources Center, Graduate School of Oceanography, University of Rhode Island and CEWEFIA and DAA. 30 pp.

Berkes, F. (2003). Alternatives to Conventional Management: Lessons from Smallscale Fisheries. Environments, 31(1), 5.

Bernard, H. R. (2017). Research Methods in Anthropology: Qualitative and Quantitative Approaches Rowman \& Littlefield.

Blattman, C., Fiala, N., \& Martinez, S. (2013). Generating Skilled Self-Employment in Developing Countries: Experimental Evidence from Uganda. The Quarterly Journal of Economics, 129(2), 697-752. 
Borda, O. F., \& Deutschmann, P. (1962). Communication and Adoption Patterns in an Andian Village. San Jose, Costa Rica, Programa Interamericano De Informacion Popular.

Bolwig, S., Ponte, S., Du Toit, A., Riisgaard, L., \& Halberg, N. (2010). Integrating Poverty and Environmental Concerns into Value-Chain Analysis: A Conceptual Framework. Development Policy Review, 28(2), 173-194.

Bostock, T., Greenhalgh, P., \& Kleih, U. (2004). Policy Research-Implications of Liberalisation of Fish Trade for Developing Countries: Synthesis Report.

Calhoun, S., Conway, F., \& Russell, S. (2016). Acknowledging the Voice of Women: Implications for Fisheries Management and Policy. Marine Policy, 74, 292299.

Cantril, H., \& Livingston, W. K. (1963). The Concept of Transaction in Psychology and Neurology. Journal of Individual Psychology, 19(1), 3.

Cattell, R. B. (1966). The Scree Test for the Number of Factors. Multivariate Behavioral Research, 1(2), 245-276.

Chaudhury, N., Friedman, J., \& Onishi, J. (2013). Philippines Conditional Cash Transfer Program Impact Evaluation 2012. Manila: World Bank Report, (75533$\mathrm{PH})$.

Cheke, R. A., \& Ward, A. (1998). A Model for Evaluating Interventions Designed to Reduce Post-Harvest Fish Losses. Fisheries Research, 35(3), 219-227.

Cinner, J., Daw, T., \& McClanahan, T. (2009). Socioeconomic Factors that Affect Artisanal Fishers' Readiness to Exit a Declining Fishery. Conservation Biology, 23(1), 124-130.

Cohen, J. (1988). Statistical Power Analysis for the Behavioral Sciences. 2nd.

Codex Alimentarius Commission. (2009). Code of Practice for the Reduction of Contamination of Food with Polycyclic Aromatic Hydrocarbons (PAH) from Smoking and Direct Drying Processes. Cac/rcp, 68.

Cooksey, K. (2014). Modified Atmosphere Packaging of Meat, Poultry and Fish. Innovations in Food Packaging (second edition) (pp. 475-493) Elsevier.

Crawford, B., Gonzales, L., Amin, D., Nyari-Hardi, B., \& Sarpong, Y. (2016). Report on the Baseline Survey of Small Pelagic Fishing Households Along the Ghana Coast. The USAID/Ghana Sustainable Fisheries Management Project (SFMP) Narragansett, RI: Coastal Resources Center, Graduate School of Oceanography, University of Rhode Island.GH2014_PGM187_CRC.122pp. 
Crawford, B., Herrera, M. D., Hernandez, N., Leclair, C. R., Jiddawi, N., Masumbuko, S., \& Haws, M. (2010). Small Scale Fisheries Management: Lessons from Cockle Harvesters in Nicaragua and Tanzania. Coastal Management, 38(3), 195-215.

Da Silva, D. (2011). Value Chain of Fish and Fishery Products: Origin, Functions and Application in Developed and Developing Country Markets. Food and Agriculture Organization. 63pp.

De Marchi, V. D., Maria, E. D., \& Micelli, S. (2013). Environmental Strategies, Upgrading and Competitive Advantage in Global Value Chains. Business Strategy and the Environment, 22(1), 62-72.

Demont, M., \& Ndour, M. (2015). Upgrading Rice Value Chains: Experimental Evidence from 11 African Markets. Global Food Security, 5, 70-76.

Dentoni, D., \& English, F. (2012). Dealing with Cultural Differences in Public-Private R\&D Projects: The Experience of the Australian Seafood Sector. International Food and Agribusiness Management Review, 15(A), 127-132.

Dewees, C., \& Hawkes, G. (1988). Technical Innovation in the Pacific Coast Trawl Fishery: The Effects of Fishermen's Characteristics and Perceptions on Adoption Behavior. Human Organization, 47(3), 224-234.

Diei-Ouadi, Y., \& Mgawe, Y. I. (2011). Post-Harvest Fish Loss Assessment in SmallScale Fisheries. A Guide for the Extension Officer. FAO Fisheries and Aquaculture Technical Paper, (559).

Entee, S. (2015). Post-Harvest Processing Value Chain Literature Review Report. The USAID/Ghana Sustainable Fisheries Management Project (SFMP). Narragansett, RI: Coastal Resources Center, Graduate School of Oceanography, University of Rhode Island and Netherlands Development Organization.GH2014_ACT022_SNV.36pp.

European Food Safety Authority. (2008). Polycyclic Aromatic Hydrocarbons in Food. Scientific Opinion of the Panel on Contaminants in the Food Chain. European Food Safety Authority Journal 724, 114p.

Evangelista, D. (1992). Management of Mangrove Areas in Calauag Bay, Quezon Province, Philippines.

Fafanding, S. F., Tobey, J., \& Drammeh, O. (2010). Sole Fishery Value Chain Assessment. Narragansett, RI: Coastal Resources Center, University of Rhode Island. Retrieved from http://www.crc.uri.edu/download/Final_Sole_VCA_Report_August_201 01.pdf. 
Fabinyi, M. (2016). Producing for Chinese Luxury Seafood Value Chains: Different Outcomes for Producers in the Philippines and North America. Marine Policy, 63, 184-190.

Fauzi, A., \& Zuzy, A. (2010). Social Resilience and Uncertainties: The Case of SmallScale Fishing Households in the North Coast of Central Java. Mast, 9(2), 5564.

Fishery Progress. (2018). Gambia Sole-Bottom Set Gillnet. Retrieved from https:/fisheryprogress.org/fip-profile/gambia-sole-bottom-set-gillnet.

Food and Agriculture Organization of the United Nations (FAO). (2008). Many of the World's Poorest People Depend on Fish. Retrieved from http://www.fao.org/Newsroom/en/news/2005/102911/index.html.

Food and Agriculture Organization of the United Nations (FAO). (2014). The State of Fisheries and Aquaculture. Opportunities and Challenges. ( No. E-ISBN 97892-5-108276-8). Rome: FAO. Retrieved from http://www.fao.org/3/ai3720e.pdf.

Food and Agriculture Organization of the United Nations. (2015). Voluntary Guidelines for Securing Sustainable Small-Scale Fisheries in the Context of Food Security and Poverty Eradication. Rome. Food and Agriculture Organzation of the United Nations.

Food and Agriculture Organization of the United Nations (FAO). (2015). The Global Forest Resources Assessment. ( No. ISBN-978-92-5-108826-5). Rome. Retrieved from http://www.fao.org/3/a-i4808e.pdf.

Food and Agriculture Organization of the United Nations. (February, 2016). Fishery and Aquaculture Country Profiles. The Republic of Ghana. Retrieved August 12, 2018 from http://www.fao.org/fishery/facp/GHA/en.

Food and Agriculture Organization of the United Nations (FAO). (2018). Fisheries and Aquaculture Department. People and Communities. Retrieved from http://www.fao.org/fishery/ssf/people/en

Friends of the Nation (2015). The USAID/Ghana Sustainable Fisheries Management Project (SFMP), Anti-Child Labour and Trafficking Field PRA Survey Report. Narragansett, RI: Coastal Resources Center, Graduate School of Oceanography, University of Rhode Island. 90p.

Gereffi, G. (1999). International Trade and Industrial Upgrading in the Apparel Commodity Chain. Journal of International Economics, 48(1), 37-70.

Gereffi, G., \& Fernandez-Stark, K. (2011). Global Value Chain Analysis: A Primer. Center on Globalization, Governance \& Competitiveness (CGGC), Duke University, North Carolina, USA. 
Gereffi, G., Humphrey, J., \& Sturgeon, T. (2005). The Governance of Global Value Chains. Review of International Political Economy, 12(1), 78-104.

Golden, C., Allison, E. H., Cheung, W. W., Dey, M. M., Halpern, B. S., McCauley, D. J., . . Myers, S. S. (2016). Fall in Fish Catch Threatens Human Health. Nature, 534 (7607), 317-320.

Gordon, A., Pulis, A., \& Owusu-Adjei, E. (2011). Smoked Marine Fish from Western Region, Ghana: A Value Chain Assessment. World Fish Center. 41pp.

Hamilton-Hart, N., \& Stringer, C. (2016). Upgrading and Exploitation in the Fishing Industry: Contributions of Value Chain Analysis. Marine Policy, 63, 166-171.

Hall, G. M. (2011). Fish Processing: Sustainability and New Opportunities. John Wiley \& Sons. Oxford, UK.

Harland, C. M. (1996). Supply Chain Management: Relationships, Chains and Networks. British Journal of Management, 7(s1), S63-S80.

Hara, M. M. (2014). Analysis of South African Commercial Traditional Linefish Snoek Value Chain. Marine Resource Economics, 29(3), 279-299.

Harlow, L. (2014). The Essence of Multivariate Thinking: Basic Themes and Methods. Routledge. New York.

Harper, S., Zeller, D., Hauzer, M., Pauly, D., \& Sumaila, U. R. (2013). Women and Fisheries: Contribution to Food Security and Local Economies. Marine Policy, 39, 56-63.

Heck, S., Béné, C., \& Reyes-Gaskin, R. 2007. Investing in African Fisheries: Building Links to the Millennium Development Goals. Fish and Fisheries, 8(3), 211226.

Hempel, E. (2010). Value Chain Analysis in the Fisheries Sector in Africa. Note: Study Carried Out in Collaboration with INFOSA and Funded by the Trade Working Group of the PARTNERSHIP FOR AFRICAN FISHERIES, an AU/NEPAD Programme.

Huss, H. H. (1988). Fresh Fish-Quality and Quality Changes: A Training Manual Prepared for the FAO/DANIDA Training Programme on Fish Technology and Quality Control Food \& Agriculture Org.

Institute for Industrial Research [CSIR], Ghana Standards Authority [GSA], Kwarteng, E. (2016). Testing of low PAH Improved Fish Smoking Stove (Ahotor oven). The USAID/Ghana Sustainable Fisheries Management Project (SFMP), Narragansett, RI: Coastal Resources Center, Graduate School of Oceanography, University of Rhode Island. GH2014_ACT067_SNV.19p. 
James, J. (2013). The Diffusion of IT in the Historical Context of Innovations from Developed Countries. Social Indicators Research, 111(1), 175-184.

Kabahenda, M., Omony, P., \& Hüsken, S. (2009). Post-Harvest Handling of LowValue Fish Products and Threats to Nutritional Quality: A Review of Practices in the Lake Victoria Region. Fisheries and HIV/AIDS in Africa: Investing in Sustainable Solutions, the WorldFish Center.

Kaplinsky, R. (2000). Globalisation and Unequalisation: What Can be Learned from Value Chain Analysis? Journal of Development Studies, 37(2), 117-146.

Kaplinsky, R., \& Morris, M. (2000). A Handbook for Value Chain

Research University of Sussex, Institute of Development Studies.

Karl, H., \& Leinemann, M. (1996). Determination of Polycyclic Aromatic Hydrocarbons in Smoked Fishery Products from Different Smoking Kilns. Zeitschrift Für Lebensmittel-Untersuchung Und Forschung, 202(6), 458464.

Kawarazuka, N., \& Béné, C. (2011). The Potential Role of Small Fish Species in Improving Micronutrient Deficiencies in Developing Countries: Building Evidence. Public Health Nutrition, 14(11), 1927-1938.

Kebede, E., Kagochi, J., \& Jolly, C. M. (2010). Energy Consumption and Economic Development in sub-Sahara Africa. Energy Economics, 32(3), 532-537.

Kelleher, K. (2005). Discards in the World's Marine Fisheries: An Update Food \& Agriculture Organization. Rome.

Kwarteng, E. (2015). Fuelwood Value Chain Analysis Literature Review Report. The USAID/Ghana Sustainable Fisheries Management Project (SFMP). Narragansett, RI: Coastal Resources Center, Graduate School of Oceanography, University of Rhode Island and SNV Netherlands Development Organization.GH2014_SCI010_SNV.91pp.

Kwarteng, E., Nsiah, A., \& Aziebor, E. (2016). Energy Expenditure and Comparative Economics of Fish Processing Techniques Report. The USAID/Ghana Sustainable Fisheries Management Project (SFMP). Narragansett, RI: Coastal Resources Center, Graduate School of Oceanography, University of Rhode Island.GH 2014_ACT076_SNV.34pp.

Lao, J., Xie, S., Wu, C., Bao, L., Tao, S., \& Zeng, E. Y. (2018). Importance of Dermal Absorption of Polycyclic Aromatic Hydrocarbons Derived from Barbecue Fumes. Environmental Science \& Technology, 52(15), 8330-8338.

LaGra, J. (1990). A Commodity Systems Assessment Methodology for Problem and Project Identification. A Commodity Systems Assessment Methodology for Problem and Project Identification. Appendix A Post-Harvest Loss Assessment. http://ucanr.edu/datastoreFiles/234-1319.pdf. 
Lazar, N., Asare, C., Nortey, D., Kankam, S., \& Agbogah, K. (2016). The Small Pelagic Fisheries Profile: Analysis of Regional Results. USAID/Sustainable Fisheries Management Project (SFMP). Narragansett, RI: Coastal Resources Center, Graduate School of Oceanography, University of Rhode Island and Hen Mpoano.GH2014_ACT001_CRC.39pp.

Lowry, K. (1985). Assessing the Implementation of Federal Coastal Policy. Journal of the American Planning Association, 51(3), 288-298.

Macfadyen, G., Nasr-Alla, A. M., Al-Kenawy, D., Fathi, M., Hebicha, H., Diab, A. M., .. . El-Naggar, G. (2012). Value-Chain Analysis-an Assessment Methodology to Estimate Egyptian Aquaculture Sector Performance. Aquaculture, 362, 18-27.

Madanda, A. (2003). Commercialization and Gender Roles among Lake Victoria Shore Fishing Communities in Uganda. Addis Abada: OSSREA. Research Report. 61pp.

Marchi, V. D., Maria, E. D., \& Micelli, S. (2013). Environmental Strategies, Upgrading and Competitive Advantage in Global Value Chains. Business Strategy and the Environment, 22(1), 62-72.

Matsue, N., Daw, T., \& Garrett, L. (2014). Women Fish Traders on the Kenyan Coast: Livelihoods, Bargaining Power, and Participation in Management. Coastal Management, 42(6), 531-554.

Moore, G. C., \& Benbasat, I. (1991). Development of an Instrument to Measure the Perceptions of Adopting an Information Technology Innovation. Information Systems Research, 2(3), 192-222.

Morrissey, M. T. (1988). Postharvest Fishery Losses: Proceedings of an International Workshop Held April 12-16, 1987, at the University of Rhode Island, Kingston, RI.

Mutimukuru-Maravanyika, T., Mills, D. J., Asare, C., \& Asiedu, G. A. (2016). Enhancing Women's Participation in Decision-Making in Artisanal Fisheries in the Anlo Beach Fishing Community, Ghana. Water Resources and Rural Development. https://doi.org/10.1016/j.wrr.2016.04.001.

Murawski, S., Methot, R., \& Tromble, G. (2007). Biodiversity Loss in the Ocean: How Bad is it? Science (New York, N.Y.), 316(5829), 1281-4; author reply 1281-4. doi:316/5829/1281b [pii].

Neiland, A. E., \& Béné, C. (2013). Poverty and Small-Scale Fisheries in West Africa. Springer Science \& Business Media. 
Nunoo, F., Asiedu, B., Amador, K., Belhabib, D., Lam, V., Sumaila, R., \& Pauly, D. (2014). Marine Fisheries Catches in Ghana: Historic Reconstruction for 1950 to 2010 and Current Economic Empacts. Reviews in Fisheries Science \& Aquaculture, 22(4), 274-283.

Odjidja, E., Yeboah, D., Abgekpornu, H., Manu, S. and K. Beran. (2016). Morrison Stove Independent Evaluation Report. The USAID/Ghana Sustainable Fisheries Management Project (SFMP). Fisheries Commission, Ministry of Fisheries and Aquaculture Development, and Coastal Resources Center, Graduate School of Oceanography, University of Rhode Island. Narragansett, RI. 55p.

O'Neill, E. D., \& Crona, B. (2017). Assistance Networks in Seafood Trade-A Means to Assess Benefit Distribution in Small-Scale Fisheries. Marine Policy, 78, 196-205.

Overa, R. (1993). Wives and Traders: Women's Careers in Ghanaian Canoe Fisheries. Maritime Anthropological Studies, 6(1-2), 110-135.

Pankratz, M., Hallfors, D., \& Cho, H. (2002). Measuring Perceptions of Innovation Adoption: The Diffusion of a Federal Drug Prevention Policy. Health Education Research, 17(3), 315-326.

Parry, R. (2012). Principles and Applications of Modified Atmosphere Packaging of Foods. Springer Science \& Business Media.

Pauly, D., \& Watson, R. (2003). Counting the Last Fish. Scientific American, 289(1), 42-47.

Pietrobelli, C., \& Rabellotti, R. (2011). Global Value Chains Meet Innovation Systems: Are There Learning Opportunities for Developing Countries? World Development, 39(7), 1261-1269.

Plahar, W. A., Nerquaye-Tetteh, G. A., \& Annan, N. T. (1999). Development of an Integrated Quality Assurance System for the Traditional Sardinella sp. and Anchovy Fish Smoking Industry in Ghana. Food Control, 10(1), 15-25.

Poggie Jr, J. (1972). Toward Quality Control in Key Informant Data. Human Organization, 31(1), 23-30.

Pollnac, R. B., \& Crawford, B. R. (2000). Assessing Behavioral Aspects of Coastal Resource Use. Proyek Pesisir Publications Special Report. Coastal Resources Center Coastal Management Report \#2226. Coastal Resources Center, University of Rhode Island, Narragansett, Rhode Island. 139pp.

Pollnac, R. B., Pomeroy, R. S., \& Harkes, I. H. (2001). Fishery Policy and Job Satisfaction in Three Southeast Asian Fisheries. Ocean \& Coastal Management, 44(7-8), 531-544. 
Pollnac, R. B., \& Poggie, J., John J. (2006). Job Satisfaction in the Fishery in Two Southeast Alaskan Towns. Human Organization, 65(3), 329-339.

Pomeroy, R. S., \& Andrew, N. (2011). Small-Scale Fisheries Management:

Frameworks and Approaches for the Developing World. Oxfordshire, UK and Cambridge, MA: Cabi.

Ponte, S., Kelling, I., Jespersen, K. S., \& Kruijssen, F. (2014). The Blue Revolution in Asia: Upgrading and Governance in Aquaculture Value Chains. World Development, 64, 52-64.

Porter, M. E. (1985). Competitive Advantage: Creating and Sustaining Superior Performance. The Free Press. New York.

Porter, M. E. (1998). Clusters and the New Economics of Competition. Harvard Business Review Boston.

Porter, M. E., \& Kramer, M. R. (2006). The Link Between Competitive Advantage and Corporate Social Responsibility. Harvard Business Review, 84(12), 78-92.

Purcell, S. W., Crona, B. I., Lalavanua, W., \& Eriksson, H. (2017). Distribution of Economic Returns in Small-Scale Fisheries for International Markets: A Value-Chain Analysis. Marine Policy, 86, 9-16.

Quinn, N. (1978). Do Mfantse Fish Sellers Estimate Probabilities in Their Heads? American Ethnologist, 5(2), 206-226.

Quisumbing, A. R., \& Pandolfelli, L. (2010). Promising Approaches to Address the Needs of Poor Female Farmers: Resources, Constraints, and Interventions. World Development, 38(4), 581-592. doi:https://doi.org/10.1016/j.worlddev.2009.10.006.

Richardson, J. T. (2011). Eta Squared and Partial eta Squared as Measures of Effect Size in Educational Research. Educational Research Review, 6(2), 135-147.

Riisgaard, L., Bolwig, S., Ponte, S., Du Toit, A., Halberg, N., \& Matose, F. (2010). Integrating Poverty and Environmental Concerns into Value-Chain Analysis: A Srategic Framework and Practical Guide. Development Policy Review, 28(2), 195-216.

Robson, C. (2011). Real World Research: A Resource for Users of Social Research Methods in Applied Settings 3rd Edition.

Röling, N. (2010). The Impact of Agricultural Research: Evidence from West Africa, Development in Practice, 20:8, 959-971, DOI: 10.1080/09614524.2010.513724.

Rogers E. M. (1995). Diffusion of Innovations (Fourth Edition). The Free Press. New York. 
Rosales, R. M., Pomeroy, R., Calabio, I. J., Batong, M., Cedo, K., Escara, N., . . . Sarahadil, M. (2017). Value Chain Analysis and Small-Scale Fisheries Management. Marine Policy, 83, 11-21.

Rummel, R. J. (1970). Applied Factor Analysis. Northwestern University Press. Evanston.

Ryan, B., \& Gross, N. C. (1943). The Diffusion of Hybrid Seed Corn in Two Iowa Communities. Rural Sociology, 8(1), 15.

Santos, A. N. (2015). Fisheries as a Way of Life: Gendered Livelihoods, Identities and Perspectives of Artisanal Fisheries in Eastern Brazil. Marine Policy, 62, 279288.

Sea Temperature. (2017). Water Temperature Gambia in August. Retrieved from https://seatemperature.info/august/gambia-water-temperature.html.

Steckler, A., Goodman, R. M., McLeroy, K. R., Davis, S., \& Koch, G. (1992). Measuring the Diffusion of Innovative Health Promotion Programs. American Journal of Health Promotion, 6(3), 214-224.

Stephenson, G. O. (1980). " Pushing for the highline": The Diffusion of Innovations in the Oregon Otter Trawl Fishery. Master of Arts Thesis. Retrieved August 12, 2018 from https://ir.library.oreganstate.edu/downloads/7h149t88k.

Tango-Lowy, T., \& Robertson, R. A. (2002). Predisposition Toward Adoption of Open Ocean Aquaculture by Northern New England's Inshore, Commercial Fishermen. Human Organization, 61(3), 240-251.

The Gambia Department of Fisheries Statistics Unit. (2015).

Thilsted, S. H., Thorne-Lyman, A., Webb, P., Bogard, J. R., Subasinghe, R., Phillips, M. J., \& Allison, E. H. (2016). Sustaining Healthy Diets: The Role of Capture Fisheries and Aquaculture for Improving Nutrition in the Post-2015 Era. doi:https://doi.org/10.1016/j.foodpol.2016.02.005.

Thorpe, A., \& Bennett, E. (2004). Market-Driven International Fish Supply Chains: The Case of Nile Perch from Africa's Lake Victoria. International Food and Agribusiness Management Review, 7(4), 40-57.

Thorpe, A., Reid, C., Van Anrooy, R., \& Brugere, C. (2005). When Fisheries Influence National Policy-Making: An Analysis of the National Development Strategies of Major Fish-Producing Nations in the Developing World. Marine Policy, 29(3), 211-222.

Tobey, J., Normanyo, A., Osei, P., Beran, K., \& Crawford, B. (2016). Subsidies in Ghana’s Marine Artisanal Fisheries Sector. USAID/Ghana Sustainable Fisheries Management Project (SFMP). Narragansett, RI: Coastal Resources Center, Graduate School of Oceanography, University of Rhode Island.GH2014_POL059_CRC.53pp. 
Tornatzky, L. G., \& Klein, K. J. (1982). Innovation Characteristics and Innovation Adoption-Implementation: A Meta-Analysis of Findings. IEEE Transactions on Engineering Management, (1), 28-45.

Uchida, H. (2017). TURFs, Collective Fishery Management, and Fishery Cooperatives. Bulletin of Marine Science, 93(1), 83-99.

United Nations. (2014). The Fisheries Sector in The Gambia: Trade, Value Addition and Social Inclusiveness, with a Focus on Women. (Analytical report). New York: United Nations.

United Nations. (2016). Sustainable Development Goals Report 2016 United Nations. New York.

United States Agency for International Development. (2014). Gambia-Senegal Sustainable Fisheries Project (USAID/BaNafaa) Final Report. (Final Report No. 624-A-00-09-00033-00). Narragansett, RI: Coastal Resources Center, University of Rhode Island Graduate School of Oceanography. http://pdf.usaid.gov/pdf_docs/PA00K5JG.pdf.

USAID. 2011. Feed the Future FY 2011-2015 Multi-year Strategy. U.S> Government Document Approved February 22, 2011.

http://www.feedthefuture.gov/sites/default/files/country/strategies/files/Ghana FeedtheFutureMulti-YearStrategy 2011-08-03.pdf.

Walker, B. L. E. (2001). Sisterhood and Seine-nets: Engendering Development and Conservation in Ghana's Marine Fishery. The Professional Geographer, 53(2), 160-177.

Walker, B. L. E. (2002). Engendering Ghana's Seascape: Fanti Fish Traders and Marine Property in Colonial History. Society \&Natural Resources, 15(5), 389407.

Ward, A., \& Jeffries, D. (2000). A Manual for Assessing Post-Harvest Fisheries Losses. Overseas Development Administration. Natural Resources Institute. University of Greenwich.

Washington, S. (2009). Private Standards in Fisheries and Aquaculture: Current Practice and Emerging Issues. GLOBEFISH Research Programme, 97, I.

Weeratunge, N., Snyder, K. A., \& Sze, C. P. (2010). Gleaner, Fisher, Trader, Processor: Understanding Gendered Employment in Fisheries and Aquaculture. Fish and Fisheries, 11(4), 405-420. 
Wentink, C. R., Raemaekers, S., \& Bush, S. R. (2017). Co-Governance and Upgrading in the South African Small-Scale Fisheries Value Chain. Maritime Studies, 16(1), 5.

WorldFish Center. (2008). Small-Scale Capture Fisheries: A Global Overview with Emphasis on Developing Countries: A Preliminary Report of the Big Numbers Project. The WorldFish Center Working Papers.

World Food Summit. (1998). Conference on Attaining the World Food Summit's Objectives Through a Sustainable Development Strategy Following the Plan of Action at the World Food Summit in 1996. Rome. http://archive.ipu.org/splze/rome98.htm.

World Health Organization. (2018). International Food Standards (FAO/WHO Codes Alimentarius. Retrieved August 12, 2018 http://www.who.int/foodsafety/areas_work/food-standard/en/. 